NUREG/CR-6487

UCRL-ID-124822

\title{
Containment Analysis for Type B \\ Packages Used to Transport Various Contents
}

Manuscript Completed: October 1996

Date Published: November 1996

Prepared by

B. L. Anderson, R. W. Carlson, L. E. Fischer

Lawrence Livermore National Laboratory

7000 East Avenue

Livermore, CA 94550

Prepared for

Office of Nuclear Material Safety and Safeguards

Spent Fuel Project Office

U.S. Nuclear Regulatory Commission

Washington, DC 20555-0001

NRC Job Code A0291 


\section{DISCLAIMER}

This report was prepared as an account of work sponsored by an agency of the United States Government. Neither the United States Government nor any agency thereof, nor any of their employees, makes any warranty, express or implied, or assumes any legal liability or responsibility for the accuracy, completeness, or usefulness of any information, apparatus, product, or process disclosed, or represents that its use would not infringe privately owned rights. Reference herein to any specific commercial product, process, or service by trade name, trademark, manufacturer, or otherwise does not necessarily constitute or imply its endorsement, recommendation, or favoring by the United States Government or any agency thereof. The views and opinions of authors expressed herein do not necessarily state or reflect those of the United States Government or any agency thereof. 


\section{DISCLAIMER}

Portions of this document may be illegible in electronic image products. Images are produced from the best available original document. 


\section{ABSTRACT}

This report presents sample containment analyses and examples of leakage rate calculations for Type B packages used to transport various contents. Samples of acceptance standard leakage rates are developed for specific contents types at normal transport conditions and at hypothetical accident conditions. The leakage rates are expressed as allowable standard leakage rates. The types of contents considered include: (1) powders, (2) liquids, (3) irradiated fuel rods, (4) gases, and (5) solids. 


\section{CONTENTS}

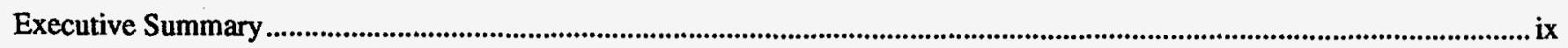

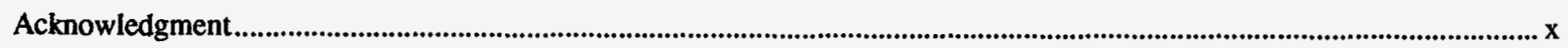

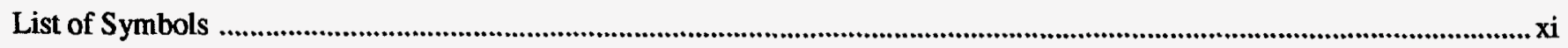

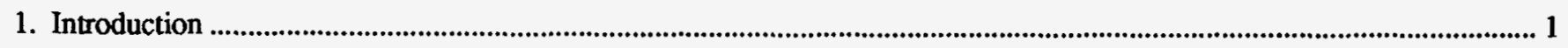

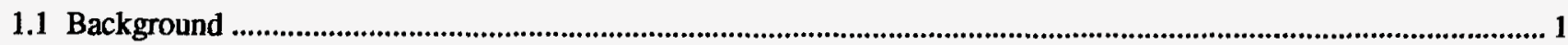

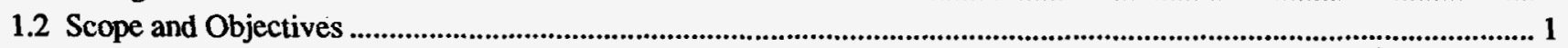

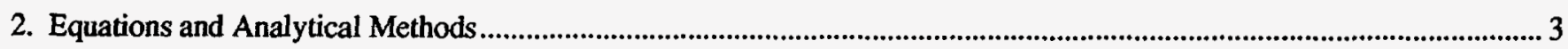

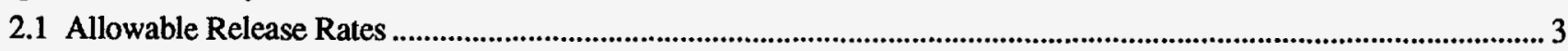

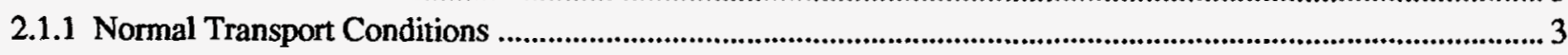

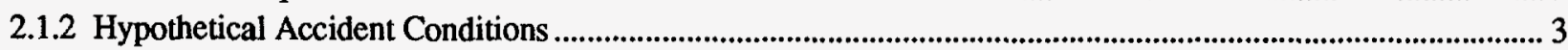

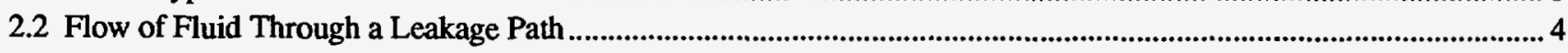

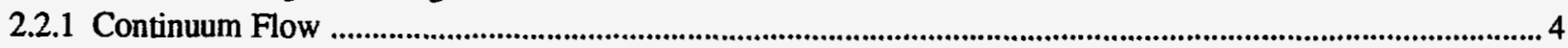

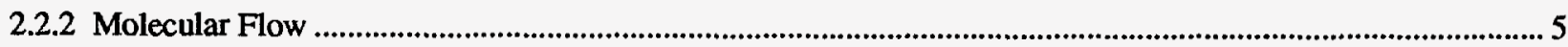

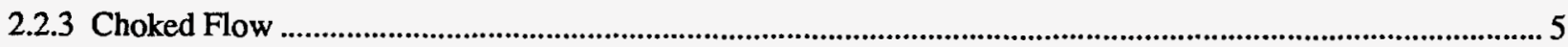

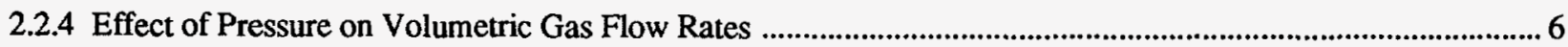

2.2.5 Applicability of Constitutive Equations for Prediction of Gas Flow Rates ..................................................... 6

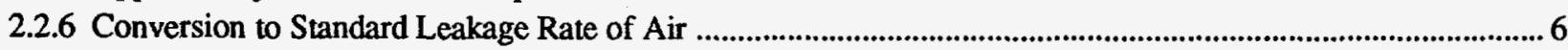

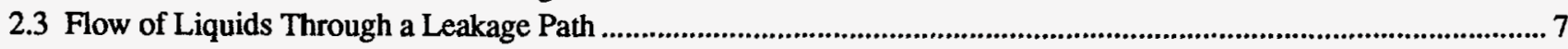

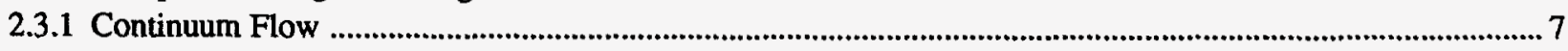

2.3.2 Liquid Flashing as the Pressure is Reduced or the Temperature is Increased Along a Leakage Path................. 7

2.3.3 Conversion to Reference Leakage Rate of Air (Standard Leak Rate) ............................................................. 8

2.3.4 Comparison of Measured and Predicted Liquid Flow Rates ...................................................................... 8

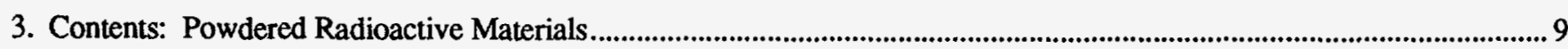

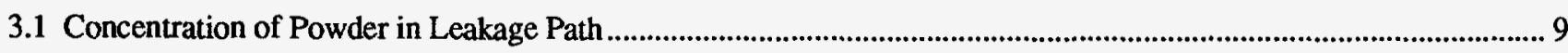

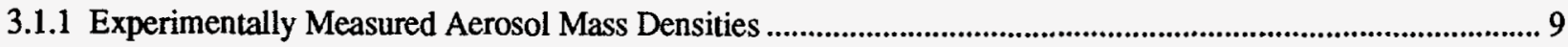

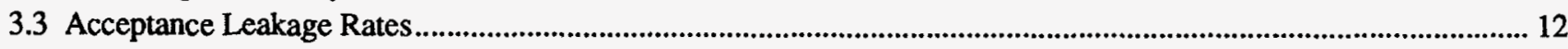

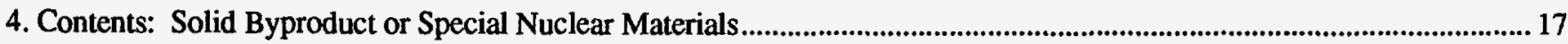

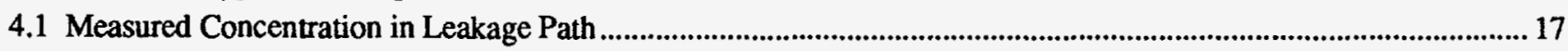

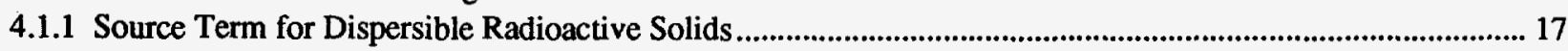

4.1.2 Source Term for Non-Dispersible Solids With Radioactive Surface Contamination ........................................ 17

4.2 Characteristics of Packages that Transport Solid Byproduct or Special Nuclear Materials ........................................ 17

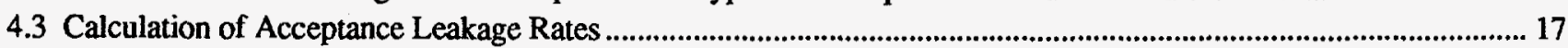

4.3.1 Allowable Standard Leak Rate for Containers Designed to Transport Dispersible Radioactive Solids ............. 17

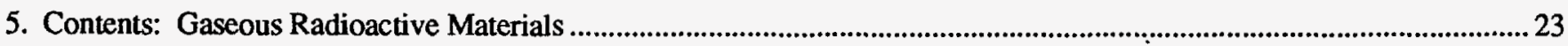

5.1 Characteristics of Packages that Transport Gaseous Nuclear Materials .................................................................23

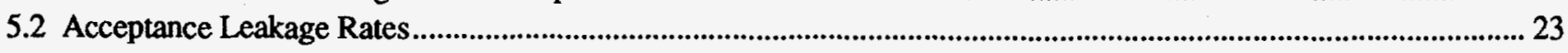

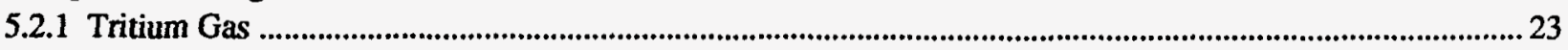

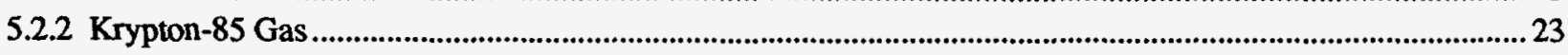

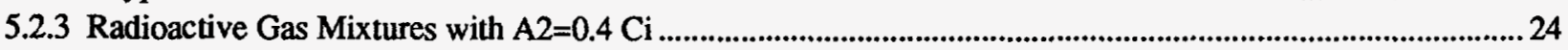

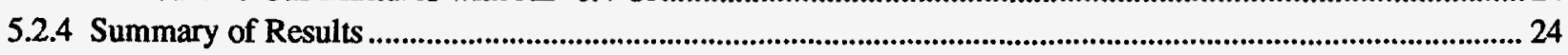

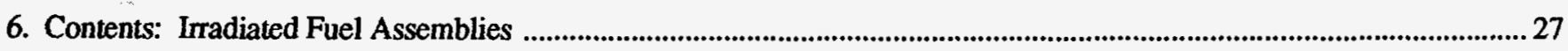

v NUREG/CR-6487 
6.1 Source Terms for Spent Nuclear Fuel Assemblies ......................................................................................................27

6.1.1 Source Activity Due to Crud Spallation from Fuel Rods ........................................................................................28

6.1.2 Source Activity due to Releases of Fines from Cladding Breaches ..............................................................28

6.1.3 Source Activity from Gases and Volatiles Released due to Cladding Breaches ................................................ 30

6.1.4 Total Source Term for Packages that Contain Irradiated Fuel Rods .................................................................. 30

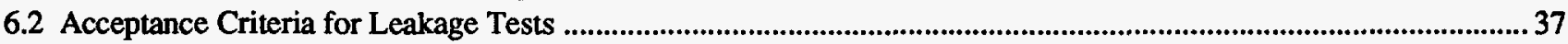

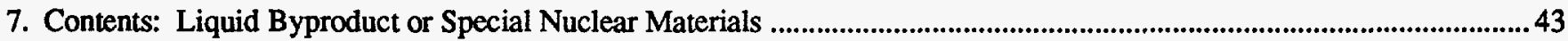

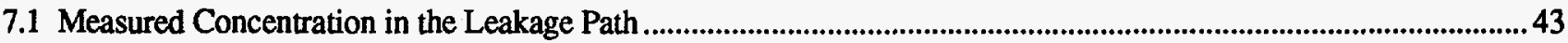

7.2 Characteristics of Packages that Transport Liquid Nuclear Materials ..................................................................4 43

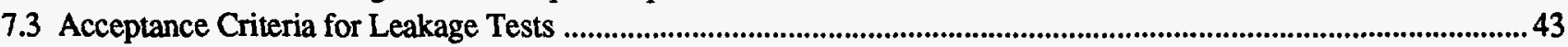

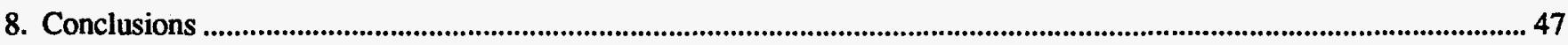

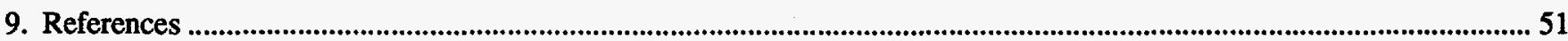

\section{FIGURES}

Figure 2-1. Ratio of calculated to measured flow rates for the flow of water through capillaries plotted as a function of the leak hole diameter from Hedley et al. (1978).

Figure 3-1. Measured volumetric flow rate versus measured mass flow rate from Schwendiman et al. for the flow of an aerosol of radioactive oxides through micro-capillaries. All the data are from experiments with the leak hole above the static powder level.

Figure 3-3. Temperatures and corresponding pressures for packages used to transport powdered radionuclides during normal transport.

Figure 3-4. Temperatures and corresponding pressures for packages used to transport powdered radionuclides during hypothetical accident conditions.

Figure 5-1a. Pressures and corresponding temperatures under normal transport conditions for packages designed to transport gaseous radionuclides.

Figure 5-1b. Pressures and corresponding temperatures under hypothetical accident conditions for packages designed to transport gaseous radionuclides.

\section{TABLES}

Table 3-1. Summary of Aerosol Densities Reported in the Literature

Table 3-2. Allowable Leakage Rates Under Normal Transport and Hypothetical Accident Conditions for Packages Used to Transport Powdered Radionuclides

Table 3-3. Acceptance Standard Leakage Rates for Packages Used to Transport Powdered Radionuclides

Table 4-1. Allowable Volumetric Leakage Rates at Normal and Hypothetical Accident Conditions for Dispersible Solids as a Function of A2/SA

Table 4-2. Representative Acceptance Standard Leakage Rates for Packages Designed to Transport Dispersible Solids as a Function of the Ratio A2/SA.

Table 5-1. Allowable Volumetric Leakage Rates Under Normal Transport Conditions and Under Hypothetical Accident Conditions for Packages Used to Transport Gaseous Radioactive Materials

Table 5-2. Acceptance Standard Leakage Rates for Packages Used to Transport Radioactive Gases

Table 6-1. Fuel Rod Cladding Breach Percentages for BWR and PWR Rods Due to Normal Handling Procedures. 
Table 6-2. Variables Used to Predict the Source Term for Packages Designed to Transport Irradiated Fuel Rods 31

Table 6-3a. Selected Physical Characteristics of PWR Fuel Rods [SA1] .............................................................................. 32

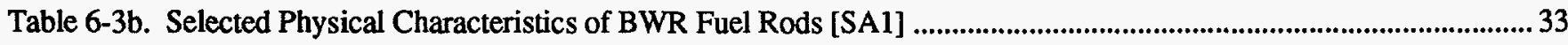

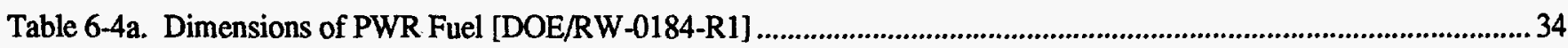

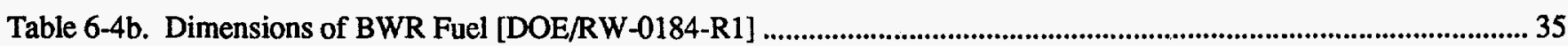

Table 6-5 Contributions to Source Term for Packages Designed to Transport Irradiated Fuel Rods. ........................................36

Table 6-6. Calculation of Effective A2 Values for the Gases and Volatiles in PWR and BWR Fuel Rods............................38

Table 6-7. Calculation of Effective A2 Values for the Releasable Material in Packages Transporting PWR or BWR Fuel Under Normal Transport Conditions or Under Hypothetical Accident Conditions .40

Table 6-8. Effective A2 of Releasable Materials and Corresponding Allowable Release Rates and Leakage Rates ...............42

Table 6-9. Acceptance Standard Leakage Rates for Packages Designed to Transport Irradiated Fuel Rods 42

Table 7-1. A2/SA and Corresponding Acceptance Standard Leakage Rates for Packages Designed to Transport Radioactive Liquids (with $\mathrm{Pu}, \mathrm{N} \leq 1.9$ atm and $\mathrm{Pu}, \mathrm{A} \leq 48.2 \mathrm{~atm}$ ) 45

Table 8-1. Summary of Representative Acceptance Standard Leakage Rates for Type B Packages with Various Content Types 


\section{EXECUTIVE SUMMARY}

Representative containment analyses for various Type B packages are performed to determine simplified acceptance standard leakage rates. The types of contents considered include: (1) powders, (2) liquids, (3) irradiated fuel rods, (4) gases, and (5) solids. For each contents type and transport condition, a simplified acceptance standard leakage rate is calculated for the various radionuclide contents. To calculate the acceptance standard leakage rate for a particular contents type and transportation conditions, the following must first be determined: allowable leakage rate; the effective $\mathrm{A}_{2}$ of the contents; the source term concentration of the releasable material; and the effective specific activity of the releasable contents. Parameters have been estimated in a way that ensures conservatism in the final calculated standard leakage rates for the conditions, contents, and packages considered. For terms not easily estimated from first principles, experimental results obtained through literature searches are used to determine the most reasonable bounding values. The calculational procedures and experimental results presented in this report may be of assistance to those performing containment analyses for Type B packages. 


\section{ACKNOWLEDGMENT}

This work was funded by the Spent Fuel Project Office, Office of Nuclear Material Safety and Safeguards, United States Nuclear Regulatory Commission. Appreciation is expressed to Nancy Osgood, the technical monitor for this work, for her assistance in developing the analyses presented in this report. 


\section{LIST OF SYMBOLS}

a

$\mathrm{A}_{\mathbf{G}}$

$A_{T}$

$A_{R}$

$A_{s}$

ASC

Av

BWR

$\mathrm{C}_{\mathrm{A}}$

$\mathrm{C}_{\text {crud }}$

$\mathrm{C}_{\text {fines }}$

$\mathrm{C}_{\text {gas }}$

$\mathrm{C}_{\mathrm{i}}(\mathrm{t})$

$\mathrm{C}_{\mathrm{N}}$

$\mathrm{C}_{\text {total }}$

$\mathrm{C}_{\mathrm{vol}}$

D

$\mathrm{D}^{\prime}$

$\mathrm{D}_{\mathrm{A}}$

$\mathrm{D}_{\mathrm{N}}$

$f_{A}$

$\mathrm{f}_{\mathrm{B}}$

$\mathrm{f}_{\mathrm{C}}$

$F_{c}$

$\mathrm{fF}_{\mathrm{F}}$

$\mathbf{f}_{\mathbf{G}}$

$F_{m}$

fv

k

L

$\mathrm{L}_{\mathrm{A}}$

$\mathrm{L}_{\mathrm{c}}$

$\mathrm{L}_{\mathrm{d}}$

$\mathrm{L}_{\mathbf{i}}$

$\mathrm{L}_{\mathrm{m}}$

$\mathrm{L}_{\mathrm{N}}$

$\mathrm{L}_{\text {std }}$

$L_{\text {std, } A}$

$L_{\text {std, } N}$

$\mathrm{L}_{\mathfrak{u}}$

m

length of capillary or orifice [cm]

specific activity of gases released from cladding breaches [Ci/g]

total surface area inside cask including fuel and baskets $\left[\mathrm{cm}^{2}\right]$

specific activity of fines $[\mathrm{Ci} / \mathrm{g}]$

settling area inside cask $\left[\mathrm{cm}^{2}\right]$

activity surface density of surface-contaminated solids $\left[\mathrm{Ci} / \mathrm{cm}^{2}\right]$

specific activity of volatiles released from cladding breaches [Ci/g]

boiling water reactor

source term activity concentration at hypothetical accident conditions $\left[\mathrm{Ci} / \mathrm{cm}^{3}\right]$

activity density in cask due to crud spallation $\left[\mathrm{Ci} / \mathrm{cm}^{3}\right]$

activity density in cask due to fines purged from cladding breaches $\left[\mathrm{Ci} / \mathrm{cm}^{3}\right]$

activity density in cask due to gases released from cladding breaches $\left[\mathrm{Ci} / \mathrm{cm}^{3}\right]$

time-dependent source term activity concentration $\left[\mathrm{Ci} / \mathrm{cm}^{3}\right], \mathrm{i}=\mathrm{N}$ or $\mathrm{A}$

source term activity concentration at normal transport conditions $\left[\mathrm{Ci} / \mathrm{cm}^{3}\right]$

total activity density inside a cask due to crud, fines, volatiles, and gases

activity density in cask due to volatiles released from cladding breaches $\left[\mathrm{Ci} / \mathrm{cm}^{3}\right]$

diameter of capillary $[\mathrm{cm}]$

diffusive plate-out velocity of particles $[\mathrm{cm} / \mathrm{s}]$

leak hole diameter that corresponds to the allowable leakage rate at hypothetical accident conditions [cm]

leak hole diameter that corresponds to the allowable leakage rate at normal transport conditions [cm]

fraction of surface contamination that spalls-off of surface-contaminated solids

fraction of fuel rods that develops a cladding breach

crud spallation fraction

coefficient for continuum flow $\left[\mathrm{cm}^{3} / \mathrm{s} \cdot \mathrm{atm}\right]$

fraction of fuel mass that is released as fines due to a cladding breach

fraction of gases in a fuel rod that is released due to a cladding breach

coefficient for molecular flow [ $\mathrm{cm}^{3} / \mathrm{atm} \cdot \mathrm{s}$ ]

fraction of volatiles in a fuel rod that are released due to a cladding breach

ratio of specific heat at constant pressure to specific heat at constant volume

volumetric flow rate $\left[\mathrm{cm}^{3} / \mathrm{s}\right]$

volumetric leakage rate at hypothetical accident conditions $\left[\mathrm{cm}^{3} / \mathrm{s}\right]$

volumetric flow rate due to continuum flow $\left[\mathrm{cm}^{3} / \mathrm{s}\right]$

volumetric flow rate at the downstream conditions $\left[\mathrm{cm}^{3} / \mathrm{s}\right]$

volumetric leakage rate $\left[\mathrm{cm}^{3} / \mathrm{s}\right], \mathrm{i}=\mathrm{N}$ or $\mathrm{A}$

volumetric flow rate due to molecular flow $\left[\mathrm{cm}^{3} / \mathrm{s}\right]$

volumetric leakage rate at normal transport conditions $\left[\mathrm{cm}^{3} / \mathrm{s}\right]$

standard leakage rate [std $\cdot \mathrm{cm}^{3} / \mathrm{s}$ ], at $25^{\circ} \mathrm{C}, \mathrm{P}_{\mathrm{u}}=1 \mathrm{~atm}, \Delta \mathrm{P}=0.99 \mathrm{~atm}$

standard leakage rate that corresponds to the release rate at hypothetical accident conditions $\left[s t d \cdot \mathrm{cm}^{3} / \mathrm{s}\right.$ ]

standard leakage rate that corresponds to the release rate at normal transport conditions $\left[\mathrm{std} \cdot \mathrm{cm}^{3} / \mathrm{s}\right.$ ]

upstream volumetric flow rate due to choked flow $\left[\mathrm{cm}^{3} / \mathrm{s}\right]$

mass flow rate $[\mathrm{g} / \mathrm{s}]$ 
molecular weight $[\mathrm{g} / \mathrm{mole}]$

$\mathrm{M}_{\mathrm{T}} \quad$ total crud activity inventory on fuel surface [Ci]

$\mathrm{N}_{\mathrm{A}} \quad$ number of assemblies in a transportation cask

$\mathrm{N}_{\mathrm{R}} \quad$ number of fuel rods per assembly

$\mathrm{P}_{\mathrm{d}} \quad$ downstream pressure [atm]

$\mathrm{P}_{\mathrm{d}, \mathrm{A}}$ downstream pressure at $\mathrm{HAC}[\mathrm{atm}]$

$\mathrm{P}_{\mathrm{d}, \mathrm{N}}$ downstream pressure at NTC [atm]

$P_{\mathbf{u}} \quad$ upstream pressure [atm]

$\mathrm{P}_{\mathrm{u}, \mathrm{A}} \quad$ upstream pressure at hypothetical accident conditions [atm]

$\mathrm{P}_{\mathrm{u}, \mathrm{N}} \quad$ upstream pressure at normal transport conditions [atm]

PWR pressurized water reactor

I

R

$\mathbf{R}_{\mathbf{A}}$

$\mathrm{R}_{\mathrm{N}}$

distance from centerline in capillary [cm]

radius of capillary or orifice [cm]

$\mathbf{R}_{\mathbf{O}}$

release rate at hypothetical accident conditions [Ci/s]

$\mathbf{R}_{\mathbf{O}}$

$S_{\text {AR }}$

release rate at normal transport conditions $[\mathrm{Ci} / \mathrm{s}]$

$S_{A S}$

$S_{C}$

$S_{\mathrm{i}}(\mathrm{t})$

$T_{d}$

$T_{u}$

$\mathrm{V}$

universal gas law constant $\left[8.31 \times 10^{7} \mathrm{erg} / \mathrm{gmol} \cdot \mathrm{K}\right]$

$\mathbf{v}_{\mathbf{S}}$ specific activity of a material or mixture [Ci/g]

surface area per fuel rod $\left[\mathrm{cm}^{2}\right]$

AS

surface area of surface-contaminated solids $\left[\mathrm{cm}^{2}\right]$

crud surface activity $\left[\mathrm{Ci} / \mathrm{cm}^{2}\right]$

time-dependent activity release rate $[\mathrm{Ci} / \mathrm{s}]$

temperature at the downstream conditions $[\mathrm{K}]$

temperature at the upstream pressure $[\mathrm{K}]$

void volume of containment vessel $\left[\mathrm{cm}^{3}\right]$

gravitational particle settling velocity $[\mathrm{cm} / \mathrm{s}]$

$v_{z} \quad$ local fluid velocity in a tube $[\mathrm{cm} / \mathrm{s}]$

$\left\langle\mathrm{v}_{\mathrm{Z}}\right\rangle \quad$ average velocity of fluid in a capillary $[\mathrm{cm} / \mathrm{s}]$

$\mathrm{W}_{\mathrm{R}} \quad$ weight of a fuel rod [g]

$\Delta \mathrm{p} \quad$ pressure drop across a capillary [atm]

$\mu \quad$ viscosity of fluid $[\mathrm{cP}]$

$\rho_{\mathrm{d}} \quad$ fluid density at the downstream conditions $\left[\mathrm{g} / \mathrm{cm}^{3}\right]$

$\rho_{u} \quad$ fluid density at the upstream conditions $\left[\mathrm{g} / \mathrm{cm}^{3}\right]$ 


\section{CONTAINMENT ANALYSIS FOR TYPE B PACKAGES USED TO TRANSPORT VARIOUS CONTENTS}

\section{Introduction}

\subsection{Background}

Containment requirements for packages used to transport radioactive materials have been developed to ensure that any release of radioisotopes during normal transportation or hypothetical accident conditions falls within regulatoryspecified limits. Although shipping packages are designed to contain the radioactivity and to maintain their structural integrity under the most severe reasonably anticipated conditions, leak testing is necessary to ensure that the packages are manufactured and assembled correctly and that no unacceptable leak paths have developed with subsequent use. Typically, calculation of acceptable leakage rates needs to be performed on a case-by-case basis depending on the leak rate criteria for the radioisotope(s), form of the radioisotope(s), package type, and conditions of transport. This report presents containment analyses and the resulting generalized containment criteria for classes of packages used to ship materials of similar forms. Satisfaction of the containment criteria, expressed as standard leakage rates, ensures that the packages will not exceed the regulatory-dictated allowable radionuclide release rate. The leak testing analyses presented in this report are conservative estimates of the maximum allowable leak rate as necessitated by their generality for a given class of packages.

\subsection{Scope and Objectives}

American National Standards Institute (ANSI) standard N14.5 presents a methodology for determining the acceptance criteria for leakage testing of radionuclide shipping packages. Leak testing is required (1) after the initial fabrication prior to first use, (2) before each shipment, (3) after third use, and (4) annually. The content of the ANSI standard has been accepted by the Nuclear Regulatory Commission (NRC) staff as an acceptable method for meeting the leakage requirements presented in Title 10 of the United States Code of Federal Regulations, Part 71 (10 CFR 71). The ANSI N14.5 standard specifies (1) package containment requirements, (2) methods of relating package containment requirements to measured release and leakage rates, and (3) minimum requirements for release and leakage rate measurement procedures. This report describes how to perform leakage testing acceptance analysis and presents representative containment calculations. The results of these calculations are condensed into a representative set of simplified acceptance leakage rates for packages that transport specific contents.

The two parts to determining the leakage rate acceptance criteria are: (1) calculation of the leak hole diameters in a package that correspond to the regulatory maximum allowable release rate of radionuclides (in curies) for normal transport and hypothetical accident conditions, and (2) calculation of the corresponding air flow rate through these leak holes at the standard leak test conditions. Representative acceptance leakage rates are calculated for packages designed to hold radionuclides in the following forms: powders, liquids, gases, solids, and irradiated fuel rods. In these calculations, the $A_{2}$ values used are from Table A-1 in the proposed 10 CFR 71. Additionally, packages certified for the transport of plutonium by air have not been included in this report either as data or for guidance. 


\section{Equations and Analytical Methods}

This section reviews the analytical models recommended in ANSI N14.5 for development of acceptance standard leakage rates. A brief summary of the foundation of the models and the underlying assumptions are included, particularly where they have a significant impact upon the interpretation of the calculations of the acceptance leakage rates. Flow rate predictions, obtained with the equations, are compared to experimentally measured values. Recommendations are made as to the applicability of the equations to predict the leakage rates from packages used to transport radioactive materials.

\subsection{Allowable Release Rates}

\subsubsection{Normal Transport Conditions}

The containment criterion for Type B packages under normal conditions of transport is given in $10 \mathrm{CFR}$ 71.51(a)(1). This criterion requires that a package have a radioactive release rate less than $A_{2} \times 10^{-6}$ in one hour, where $A_{2}$ has units of curies (Ci) and is dependent upon the isotopes being transported:

\section{Equation 2-1}

$\mathrm{R}_{\mathrm{N}} \leq 10^{-6} \mathrm{~A}_{2}$ /hour

Assuming that the release rate is uniform over the one-hour period, the release rate for normal transport conditions, $R_{N}$, in units of curies per second is:

\section{Equation 2-2}

$\mathrm{R}_{\mathrm{N}}=\mathrm{L}_{\mathbf{N}} \mathrm{C}_{\mathrm{N}} \leq \mathrm{A}_{2} \times 2.78 \times 10^{-10} /$ second,

where:

LN is the volumetric gas leakage rate $[\mathrm{cm} 3 / \mathrm{s}]$, and

$\mathrm{CN}$ is the curies per unit volume (termed "activity density,") of the radioactive material that passes through the leak path $[\mathrm{Ci} / \mathrm{cm} 3]$.

\subsubsection{Hypothetical Accident Conditions}

For accident conditions, 10 CFR 71 specifies that the permitted quantity of curies that can be released in one week is $\mathrm{A}_{2}$ :

\section{Equation 2-3}

$\int_{0}^{T} R_{A}(t) d t \leq A_{2}, \quad$ or $\quad R_{A} \leq \frac{A_{2}}{\text { week }}$,

where $T$ equals one week. Additionally, no more than 10 $\mathrm{A}_{2}$ of krypton-85 can be released in one week during a hypothetical accident.

The release rate for accident conditions, $\mathbf{R}_{\mathrm{A}}$, in units of curies per second is:

\section{Equation 2.4}

$\mathrm{R}_{\mathrm{A}}=\mathrm{L}_{\mathrm{A}} \mathrm{C}_{\mathrm{A}} \leq \mathrm{A}_{2} \times 1.65 \times 10^{-6} /$ second,

where:

$\mathrm{L}_{\mathrm{A}}$ is the time-averaged volumetric gas flow rate $\left[\mathrm{cm}^{3} / \mathrm{s}\right]$, and

$\mathrm{C}_{\mathrm{A}}$ is the curies per unit volume of the releasable radioactive material within the containment vessel $\left[\mathrm{Ci} / \mathrm{cm}^{3}\right]$.

Equation 2-4 follows from Equation 2-3 if a time-averaged constant flow rate is assumed. For krypton-85, the $A_{2}$ is $270 \mathrm{Ci}$ and the bounding value release rate at hypothetical accident conditions, which is $10 \mathrm{~A}_{2} /$ week, is equivalent to $4.46 \times 10^{-3} \mathrm{Ci} / \mathrm{s}$.

Knowledge of the $A_{2}$ value for a particular radionuclide or radionuclide mixture permits calculation of the allowable release rates from a shipping container leak. See 10 CFR 71 Appendix A Table A-1 for a list of $A_{2}$ values for the various radioisotopes. The activity density $\left(C_{i}\right.$, where $i=N$ for normal transport conditions, and $\mathrm{i}=\mathrm{A}$ for hypothetical accident conditions, in units of $\mathrm{Ci} / \mathrm{cm}^{3}$ ), of the releasable material held within a shipping container can be described as the product of the mass density of the releasable material $\left(\rho_{A}, g / \mathrm{cm}^{3}\right)$ and the specific activity of the releasable material $\left(\mathrm{S}_{\mathrm{A}}, \mathrm{Ci} / \mathrm{g}\right)$. Note that the releasable material may contain both radioactive and nonradioactive materials, and the mass density and specific activity of the releasable material mixture would need to be calculated for all cases except when the releasable material is composed of one radionuclide. 


\subsection{Flow of Fluid Through a Leakage Path}

Release of radioactivity from a transportation container to the environment can only occur if material inside the container can pass through a leak present in the container. For gaseous or liquid radioactive material, the leaking fluid is identical to the bulk material. For solid and powdered radionuclides, however, the material inside a transportation container that is available for release to the environment consists of small solid particles suspended in the fill gas to form an aerosol.

When modeling the flow of the fluid leaking from a transportation container, the following assumptions were made: (1) single leak path, (2) leak path is a right-circular cylinder, (3) the inlet and outlet of the leak path are sharpedged, and (4) the surface of the leak path is smooth. When modeling the flow of a powder aerosol, the effects of the aerosol particles on the gas rheological properties are neglected and no leak hole plugging mechanisms are considered. It is not expected that the aerosol particles would significantly alter the gas rheological properties since, even for the high aerosol mass density of $9 \times 10^{-6}$ $\mathrm{g} / \mathrm{cm}^{3}$, the ratio of particle mass to gas mass is approximately 0.01 .

For modeling the flow of fluid though a leakage path, three flow regimes are considered:

(1) continuum, (2) molecular, and (3) choked.

\subsubsection{Continuum Flow}

Continuum (laminar) flow is characterized by straight fluid streamlines and occurs when the Reynolds number is less than 2100. The Reynolds number is a dimensionless group defined by the product of the fluid mass density, the fluid velocity and the leak hole diameter divided by the fluid viscosity. Starting with a momentum balance and the equations of continuity, the parabolic velocity profile for continuum flow in a cylindrical tube can be derived:

\section{Equation 2-5}

$\mathrm{v}_{\mathrm{z}}=\frac{\Delta \mathrm{p} \mathrm{R}^{2}}{4 \mu \mathrm{a}}\left\lfloor 1-\left(\frac{\mathrm{r}}{\mathrm{R}}\right)^{2}\right\rfloor$

where:

$\mathbf{v}_{\mathbf{z}}$ is the fluid velocity $[\mathrm{cm} / \mathrm{s}]$,

$r$ is the radial distance from the center of the capillary $[\mathrm{cm}]$,
$\mathbf{R}$ is the radius of the capillary [cm],

$\Delta \mathrm{p} \quad$ is the pressure drop across the capillary [atm = $1.01 \times 10^{6} \mathrm{~g} / \mathrm{cm}^{2} \mathrm{~s}^{2}$.

By integrating the velocities over the leakage path crosssection, the average velocity, $\left\langle v_{\mathrm{Z}}\right\rangle$, can be expressed as:

Equation 2-6

$$
\left\langle\mathrm{v}_{\mathrm{z}}\right\rangle=\frac{\Delta \mathrm{p} \mathrm{\textrm {R } ^ { 2 }}}{8 \mu \mathrm{a}} .
$$

Then, the volumetric flow rate, $\mathrm{L}_{\mathfrak{c}}$, for continuum flow is:

\section{Equation 2-7}

$$
L_{c}=\left\langle v_{z}\right\rangle \pi R^{2}=\frac{\pi \Delta p R^{4}}{8 \mu a}=F_{c} \Delta p=F_{c}\left(P_{u}-P_{d}\right),
$$

where:

$F_{c}=\left(\pi R^{4} / 8 \mu a\right)$ is the coefficient for continuum flow. The coefficient for continuum flow in units of $\left[\mathrm{cm}^{3} / \mathrm{atm} \cdot \mathrm{s}\right]$, is:

\section{Equation 2-8}

$$
F_{c}=\frac{2.49 \times 10^{6} D^{4}}{a \mu}
$$

where:

$F_{c}$ is the coefficient for continuum flow $\left[\mathrm{cm}^{3} / \mathrm{atm} \cdot \mathrm{s}\right]$,

D is the capillary diameter $[\mathrm{cm}]$,

a is the capillary length [cm], and

$\mu \quad$ is the fluid viscosity [cP].

The volumetric flow rate given by Equation 2-7 is the flow rate at the average pressure. To obtain the flow rate at the upstream pressure, multiply Equation 2-7 by the ratio of the average pressure divided by the upstream pressure. The flow rate at the upstream pressure is important for containment calculations since the activity density of the releasable material is determined at this pressure. 


\subsubsection{Molecular Flow}

Molecular flow occurs when the mean-free path of a gas molecule is greater than the diameter of the leak path in which it is flowing. The mean-free path is the distance a gas molecule travels before encountering another gas molecule. Molecular flow tends to predominate for relatively small leak hole diameters. Starting with kinetic gas theory, equations can be developed that describe the molecular flow of gases through smooth-walled cylindrical capillaries or orifices. The volumetric flow rate, $\mathrm{L}_{\mathrm{m}}$, in units of $\left[\mathrm{cm}^{3} / \mathrm{s}\right]$ for the molecular flow of gas through a leak path with a pressure gradient driving force is:

\section{Equation 2-9}

$\mathrm{L}_{m}=\frac{3.81 \times 10^{3} \mathrm{D}^{3} \sqrt{\frac{T}{M}}}{a P_{a}}\left(P_{u}-P_{d}\right)=F_{m}\left(P_{u}-P_{d}\right)$,

where:

$L_{m}$ is the volumetric flow rate of gas at $P_{a}\left[\mathrm{~cm}^{3} / s\right]$,

$F_{m}$ is the molecular flow coefficient $\left[\mathrm{cm}^{3} / \mathrm{atm} \cdot \mathrm{s}\right]$,

D is the capillary diameter $[\mathrm{cm}]$,

$\mathrm{T}$ is the gas temperature $[\mathrm{K}]$,

$\mathrm{M}$ is the gas molecular weight $[\mathrm{g} / \mathrm{mole}]$,

$\mathrm{P}_{\mathrm{a}}$ is the average pressure, $\left(\mathrm{P}_{\mathrm{u}}+\mathrm{P}_{\mathrm{d}}\right) / 2[\mathrm{~atm}]$,

$P_{u} \quad$ is the upstream pressure [atm], and

$P_{d} \quad$ is the downstream pressure [atm].

The volumetric flow rate given by Equation $2-9$ is at the average pressure. To obtain the volumetric flow rate at the upstream pressure, multiply Equation 2-9 by the ratio of the average pressure divided by the upstream pressure.

When continuum and molecular flow occur simultaneously, the volumetric flow rate can be described by the linear combination of the respective equations (ANSI N14.51987; Shipiro 1953; Bomelburg 1977; Schwendiman and Sutter 1977):

\section{Equation 2-10}

$\mathrm{L}=\mathrm{L}_{\mathrm{c}}+\mathrm{L}_{\mathrm{m}}=\left(\mathrm{F}_{\mathrm{c}}+\mathrm{F}_{\mathrm{m}}\right)\left(\mathrm{P}_{\mathrm{u}}-\mathrm{P}_{\mathrm{d}}\right)$, where:

$\mathrm{L}$ is the volumetric gas flow rate at $\mathrm{P}_{\mathrm{a}}\left[\mathrm{cm}^{3} / \mathrm{s}\right]$,

$\mathrm{L}_{c} \quad$ is the volumetric flow rate due to continuum flow $\left[\mathrm{cm}^{3} / \mathrm{s}\right]$,

$\mathrm{L}_{m} \quad$ is the volumetric flow rate due to molecular flow $\left[\mathrm{cm}^{3} / \mathrm{s}\right.$,

$F_{c}$ is the coefficient of continuum flow $\left[\mathrm{cm}^{3} / \mathrm{atm} \cdot \mathrm{s}\right]$,

$F_{m}$ is the coefficient of free molecular flow $\left[\mathrm{cm}^{3} / \mathrm{atm} \cdot \mathrm{s}\right]$,

$P_{u} \quad$ is the upstream pressure [atm], and

$P_{d} \quad$ is the downstream pressure [atm].

Equation 2-10 is applicable to unchoked free molecular, transitional, and continuum flow. Transitional flow occurs when there are both continuum and molecular components in the total flow. When using Equation 2-10 for pure continuum or pure molecular flow, the unwanted term becomes insignificant.

The volumetric flow rate given by Equation $2-10$ is the flow rate at the average pressure. To obtain the volumetric flow rate at the upstream pressure, multiply Equation 2-10 by the ratio of the average pressure divided by the upstream pressure.

\subsubsection{Choked Flow}

Choked flow is characterized by leaking gas with an exit velocity near the speed of sound. The gas flow may be in the choked flow regime when the downstream pressure is less than about $50 \%$ of the upstream pressure. For situations when $\left(F_{c} / F_{m}\right) \geq 1$ and

\section{Equation 2-11}

$\frac{P_{d}}{P_{u}} \leq\left(\frac{2}{k+1}\right)^{\frac{k}{(k-1)}}=r_{c}$

where:

$\mathrm{k}$ is the ratio of the specific heat at constant pressure to the specific heat at constant volume, and

$r_{c}$ is the critical pressure ratio, 
the flow can be modeled as choked flow.

For choked flow, the equation describing the volumetric gas flow through a leak hole in a thin (orifice) plate is:

\section{Equation 2-12}

$$
\mathrm{L}_{\mathrm{u}}=\frac{\pi \mathrm{D}^{2}}{4} \sqrt{\frac{2 \mathrm{kR} \mathrm{T}_{\mathrm{u}}}{\mathrm{M}(\mathrm{k}+1)}}\left(\frac{2}{\mathrm{k}+1}\right)^{\frac{1}{(\mathrm{k}-1)}} \text {, at } \mathrm{P}_{\mathrm{u}} \text { and } \mathrm{T}_{\mathrm{u}} \text {, }
$$

where:

$\mathrm{L}_{\mathfrak{u}}$ is the upstream volumetric gas flow rate $\left[\mathrm{cm}^{3} / \mathrm{s}\right]$,

$\mathbf{R}_{\mathbf{o}}$ is the universal gas constant $\left[8.31 \times 10^{7} \mathrm{erg} / \mathrm{gmol} \cdot \mathrm{K}\right]$, and

$T_{\mathfrak{u}} \quad$ is the upstream temperature $[\mathrm{K}]$.

Equation 2-12 for choked flow may overestimate the leakage rate or underestimate the hole diameter for long leak paths (i.e., when the leak path is greater than 2 or 3 times the leak hole diameter).

\subsubsection{Effect of Pressure on Volumetric Gas Flow Rates}

As a result of the compressibility of gases, the volumetric flow rate is greatly affected by the gas pressure. For a given mass flow rate of gas, an increase in pressure will decrease the volumetric flow rate, and a decrease in pressure will increase the volumetric flow rate. Since the concentration of releasable radioactive material inside a containment vessel is determined at the containment vessel pressure, it is clear that the volumetric flow rate of gas leaking from the containment vessel at this upstream pressure is the important quantity to be determined for purposes of containment calculations.

However, for particular situations, it is of interest to calculate the downstream volumetric gas flow rate. This need may occur, for example, when attempting to compare the volumetric flow rate of gas measured at the downstream pressure to calculated flow rates. The mass flow rate is calculated by multiplying the volumetric flow rate at the upstream conditions by the gas density at the upstream conditions. This gas density at the upstream pressure is derived from the ideal gas law as $\rho_{u}=\left(P_{u} M\right) /\left(R_{0} T_{v}\right)$. Using the equation for choked flow as an example, the mass flow rate, $\mathrm{m}$, is given by:

\section{Equation 2-13}

$$
m=L_{u} \rho_{u}=\frac{P_{u} M}{R_{o} T_{u}} \frac{\pi D^{2}}{4} \sqrt{\frac{2 k R_{o} T_{u}}{M(k+1)}}\left(\frac{2}{k+1}\right)^{\frac{1}{(k-1)}} .
$$

To calculate the volumetric flow rate at the downstream conditions, $L_{d}$, the mass flow rate in the above equation is divided by the gas density at the downstream temperature and downstream pressure, $\rho_{d}=P_{d} M / R_{o} T_{d}$, to get:

\section{Equation 2-14}

$L_{d}=\frac{m}{\rho_{d}}=L_{u} \frac{\rho_{u}}{\rho_{d}}=\frac{P_{u}}{P_{d}} \frac{T_{d}}{T_{u}} \frac{\pi D^{2}}{4} \sqrt{\frac{2 k R_{o} T_{u}}{M(k+1)}}\left(\frac{2}{k+1}\right)^{\left(\frac{1}{(k-1)}\right)}$ or after simplification:

Equation 2-15

$$
L_{d}=\frac{P_{u}}{P_{d}} \frac{\pi D^{2}}{4} \sqrt{\frac{2 k R_{o}\left(T_{d}\right)^{2}}{M(k+1) T_{u}}}\left(\frac{2}{k+1}\right)^{\frac{1}{(k-1)}} \text {, at } P_{d} \text { and } T_{d} \text {. }
$$

\subsubsection{Applicability of Constitutive Equations for Prediction of Gas Flow Rates}

Comparing the flow rate predictions of Equation 2-10 and 2-12 to hundreds of experimental values obtained by many research groups for the flow of gases through microcapillaries and micro-orifices with diameters ranging from 1 to 250 microns, it was found that the continuum and molecular flow equation provided good agreement with the experimental results for flow rates less than about 1 $\mathrm{atm} \cdot \mathrm{cm}^{3} / \mathrm{s}$. For flow rates less than $1 \mathrm{~atm} \cdot \mathrm{cm}^{3} / \mathrm{s}$, the choked flow equation tended to overpredict the flow rate; however, this equation provided the best agreement with the experimental results for flow rates larger than about 1 $\mathrm{atm} \cdot \mathrm{cm}^{3} / \mathrm{s}$. The results of these comparisons are detailed in a paper entitled "Predicting the Pressure-Driven Flow of Gases Through Micro-Capillaries and Micro-Orifices," NUREG/CR-5403.

Since all the gas flow rates of interest for applications related to radioactive material transportation containers are less than $1 \mathrm{~atm} \cdot \mathrm{cm}^{3} / \mathrm{s}$, the continuum and molecular flow equation is used for the following analyses where the flow rate of gas is predicted.

\subsubsection{Conversion to Standard Leakage Rate of Air}

Packages used to transport radioactive materials must satisfy the calculated standard leakage rate criterion. ANSI 
N14.5 specifies that the standard leak rate, $\mathrm{L}_{\text {std }}$ which is given in units of $\mathrm{std} \cdot \mathrm{cm}^{3} / \mathrm{s}$, corresponds to the upstream volumetric flow rate of dry air with an upstream pressure of 1.0 atmosphere, a downstream pressure of 0.01 atmospheres, and a temperature of $298 \mathrm{~K}$. Although leakage tests may be performed at the standard leakage test conditions, the leak tests are typically performed at other testing conditions. However, regardless of the leak test conditions used, the acceptance criterion at the testing conditions must correspond to the calculated standard leakage rate acceptance criterion.

The standard leak rate criterion, which a given transportation package must satisfy, is calculated from the allowable volumetric leakage rate at normal transport or hypothetical accident conditions, whichever results in the most restrictive standard leakage rate. After calculating the leak hole diameter that corresponds to the allowable leak rate at transport conditions, this leak hole diameter is used along with the standard leak test conditions to calculate the maximum allowable standard leakage rate.

\subsection{Flow of Liquids Through a Leakage Path}

\subsubsection{Continuum Flow}

The equation used to predict the volumetric flow of liquid through a leakage path is the same as that used for the continuum flow of gas (see Equation 2-7):

\section{Equation 2-16}

$\mathrm{L}=\mathrm{F}_{\mathrm{c}}\left(\mathrm{P}_{\mathrm{u}}-\mathrm{P}_{\mathrm{d}}\right)$,

where:

$F_{c}$ is the coefficient for continuum flow $\left[\mathrm{cm}^{3} / \mathrm{s} \cdot \mathrm{atm}\right]$,

$\mathrm{L}$ is the volumetric flow rate $\left[\mathrm{cm}^{3} / \mathrm{s}\right]$,

$P_{u} \quad$ is the upstream pressure [atm], and

$P_{d} \quad$ is the downstream pressure [atm], and

\section{Equation 2-17}

$F_{c}=\frac{2.49 \times 10^{6} D^{4}}{a \mu}$

where:

D is the diameter of the cylindrical capillary [cm], a is the length of the capillary $[\mathrm{cm}]$, and

$\mu \quad$ is the liquid viscosity [cP].

Since liquids are relatively incompressible over the pressures typically encountered in the transportation of radioactive materials, the volumetric flow rate of liquid is the same under both the upstream and the downstream conditions.

\subsubsection{Liquid Flashing as the Pressure is Reduced or the Temperature is Increased Along a Leakage Path}

It is of interest to consider flashing of the liquid to a vapor while in the leak path to determine if this phenomena would increase or decrease the mass flow rate. This may occur if the outside of the containment vessel has a temperature greater than the boiling point of the leaking liquid. To analyze this issue, the mass flow rate of a liquid subject to a given pressure drop is compared to that of a gas subject to the same pressure drop and the same leak hole dimensions. A ratio of the mass flow rates is given by:

\section{Equation 2-18}

$\frac{m_{\text {gas }}}{m_{\text {liqui d }}}=\frac{\mathrm{L}_{\mathrm{gas}} \rho_{\mathrm{gas}}}{\mathrm{L}_{\text {liqui d }} \rho_{\text {liquid }}}=\frac{\mathrm{F}_{\mathrm{c}, \mathrm{gas}} \rho_{\mathrm{gas}} \Delta \mathrm{P}}{\mathrm{F}_{\mathrm{c} \text { liqu id }} \rho_{\text {liquid }} \Delta \mathrm{P}}=\frac{\mu_{\text {iquid }} \rho_{\mathrm{gas}}}{\mu_{\mathrm{g} \text { as }} \rho_{\text {li quid }}}$

For water at $25^{\circ} \mathrm{C}$ and $1 \mathrm{~atm}$, the liquid has a density of 1.0 $\mathrm{g} / \mathrm{cm}^{3}$ and a viscosity of $0.95 \mathrm{cP}$ and the gas has a density of $7.36 \times 10^{-4} \mathrm{~g} / \mathrm{cm}^{3}$ and a viscosity of $0.023 \mathrm{cP}$. Using these values, the ratio of gas mass flow rate to that of liquid is approximately 0.03 , which indicates that the gas flow rate is much less than the liquid flow rate. As temperature is increased, liquid viscosity and gas density both decrease, liquid density is relatively unaffected, and gas viscosity increases. So, for an increase in temperature, the ratio of gas mass flow rate to that of liquid will decrease even more than the value given above for $25^{\circ} \mathrm{C}$. For an increase in pressure to $10 \mathrm{~atm}$, the only term that will be significantly affected is the gas density, which would increase to $7.36 \times 10^{-3} \mathrm{~g} / \mathrm{cm}^{3}$, and give a mass flow rate ratio of 0.3 .

From the above calculations, it is clear that the phenomena of liquid flashing while in the leak path would not cause an increase in the mass flow rate. Therefore, predictions of liquid leakage rates, which require bounding estimates, need not include any influence due to liquid flashing along the leak path. 


\subsubsection{Conversion to Reference Leakage Rate of Air (Standard Leak Rate)}

Using Equations 2-16 and 2-17 in conjunction with the criteria for the maximum radionuclide release rates for normal transport and hypothetical accident conditions (Equations 2-2 and 2-4), the maximum leak hole size for containers used to transport liquid radionuclides that will satisfy the acceptance criteria can be calculated for a variety of Type $B$ packages used to transport radioactive liquids. The most restrictive leak hole diameter calculated for the packages is then used to calculate the reference leakage rate of air under standard leakage test conditions.

\subsubsection{Comparison of Measured and Predicted Liquid Flow Rates}

It was shown in the early 1900 's that liquids follow the equation describing continuum flow when flowing in capillaries (Prandtl and Tietjens 1934). Rates of penetration of liquids into capillaries with diameters from 290 to 740 $\mu \mathrm{m}$ were made by Washburn (1921) and from 56 to $102 \mu \mathrm{m}$ by Kissling and Gross (1970), where both showed that the measured flow rates agreed well with the predictions of the Poiseuille Equation (Equation 2-16).
Hedley et al. (1978) have made measurements on the flow rates of water through various sized circular capillaries with diameters ranging from $1 \mu \mathrm{m}$ to $50 \mu \mathrm{m}$. The downstream pressures were from 0.976 to $1.018 \mathrm{~atm}$ and the upstream pressures ranged from 1.096 to $1.993 \mathrm{~atm}$.

Examination of the ratio of the calculated flow rates to the observed flow values, where the calculated values were based on the Poiseuille Equation, shows fairly close agreement in most cases with the ratio of calculated-toobserved flow rates typically ranging from 1.69 to 0.68 . For all of the data collected, the average value for the ratio of the observed-to-calculated flow rate was 1.08 with a standard deviation of 0.27 . See Figure 2-1 for a plot of the ratio of the calculated flow rate to measured flow rate as a function of the leak hole diameter as reported by Hedley et al. (1978).

In conclusion, the continuum flow equation gives adequate predictions of the flow rates of liquid in micro-capillaries. For capillaries with diameters less than $10 \mathrm{um}$, the predicted flow rate is usually somewhat larger than the observed flow rate.

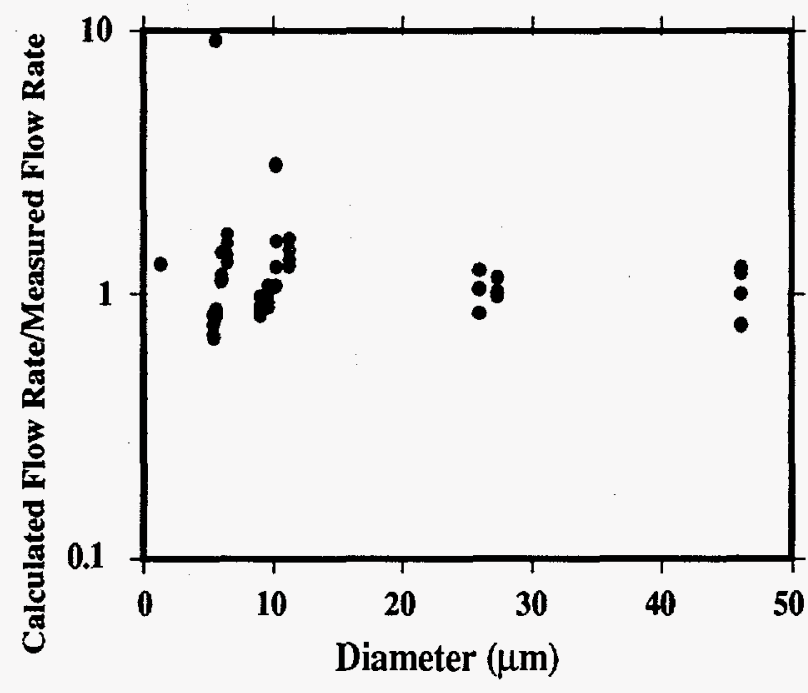

Figure 2-1. Ratio of calculated to measured flow rates for the flow of water through capillaries plotted as a function of the leak hole diameter from Hedley et al. (1978). 


\section{Contents: Powdered Radioactive Materials}

This section develops simplified acceptance standard leakage rates for packages designed to transport powdered radioactive materials. The available experimental data characterizing the concentration of powders in gases when flowing through small passages or orifices is summarized. From this summary, a bounding-value for a powder aerosol density is determined and this bounding-value is used to calculate representative acceptance standard leakage rates for the commonly transported powdered radioactive materials under both normal transport and hypothetical accident conditions.

\subsection{Concentration of Powder in Leakage Path}

When radioactive oxide powders are transported in a shipping cask, an aerosol of the powder will be generated in the free volume of the containment vessel as a result of vibration. If a leak were to develop, any escaping gas would entrain radioactive particles and result in a release of radioisotopes to the environment. Since it is difficult to accurately predict the aerosol density from first principles, experimental data is used to determine a bounding-value assessment of the powder aerosol mass density. An extensive literature review of experimental studies has been performed to collect pertinent data available on the density of aerosols made of powdered radioactive oxides; namely $\mathrm{PuO}_{2}, \mathrm{ThO}_{2}$, and $\mathrm{UO}_{2}$ (Anderson 1986; Colton \& Pettejohn 1979; Curren \& Bond 1980; Drennen et al. 1978; Fischer 1991; Kodas \& Sood 1987; Owzarski et al. 1980; Pratsinis et al. 1988; Schwendiman et al. 1976-1978; Sutter et al. 1980-1983; Yesso et al. 1980).

For the powder aerosol experiments, the powder aerosol was formed in a test chamber by injecting gas into the bottom of the test chamber under a layer of powdered oxide. The gas and entrained powder particles were allowed to leak out of a manufactured leak hole (capillary tube or orifice plate) and the leakage rate was measured. In most of the experiments surveyed for this study, the test cells were also vibrated during each run to ensure that the test conditions simulated the vibration-induced formation of an aerosol of radioactive oxide particles. Two general types of leakage rate experiments were conducted: (1) runs with the capillary tube (or orifice plate) above the static powder level, and (2) runs with the leak hole below the static powder level. The leakage experiments were performed with powders of thorium oxide, plutonium oxide, and depleted uranium oxide.

\subsubsection{Experimentally Measured Aerosol Mass Densities}

When gas leak rates $\left(\mathrm{cm}^{3} / \mathrm{s}\right)$ are plotted against mass leak rates $(\mu \mathrm{g} / \mathrm{s})$, the slope gives the aerosol mass density $\left(\mu \mathrm{g} / \mathrm{cm}^{3}\right)$. Many groups of researchers have made such measurements of mass flow rates and the corresponding volumetric flow rates. Other groups have performed direct measurements of powder aerosol densities using optical techniques.

Figure 3-1 shows the experimental results of Schwendiman et al. concerning gas leakage rates and radionuclide mass leak rates for flow paths above the static powder level. The line of best fit through the 225 data points in Fig. 3.1 gives an aerosol density of $0.00976 \mu \mathrm{g} / \mathrm{cm}^{3}$ (or $9.76 \times 10^{-9} \mathrm{~g} / \mathrm{cm}^{3}$ ). Using the density that corresponds to the line-of-best-fit, however, would tend to underpredict the aerosol density for some cases. The maximum density measured for these experiments was $4.67 \times 10^{-7} \mathrm{~g} / \mathrm{cm}^{3}$.

Since there may be a leak in the gasket area of a package when it is situated on its side or upside-down, it is relevant to consider experiments performed with the leak hole below the static powder level. Figure 3-2 shows the measured volumetric leakage rate versus the measured mass flow rate from Schwendiman et al. (1976-1978) for experiments done with the leak hole below the static powder level. The calculated line-of-best-fit through the 111 data points gives a density of $5.65 \times 10^{-8} \mathrm{~g} / \mathrm{cm}^{3}$. The maximum aerosol density measured in these experiments was $3.8 \times 10^{-6} \mathrm{~g} / \mathrm{cm}^{3}$. The aerosol density calculated from the line-of-best-fit when the flow path is below the static powder level is approximately five times greater than the experiments done with the flow path above the static powder level. In summary, the data from Schwendiman et al. gave a larger aerosol density for the experiments with the leak hole under the static powder level. It follows that more radioactive oxide particles would be entrained in the gas escaping from a hole situated under the powder.

Other reports in the literature describe similar leak rate experiments using radioactive oxide powders (Curren \& Bond 1980; Yesso et al. 1980). Curren et al. measured aerosol densities of depleted uranium oxide powder between $1.7 \times 10^{-7} \mathrm{~g} / \mathrm{cm}^{3}$ and $4.5 \times 10^{-7} \mathrm{~g} / \mathrm{cm}^{3}$ for cases in which the capillaries were above the static powder level. When the test apparatus was tilted so that the capillary was brought closer to the powder level, the aerosol density increased by approximately a factor of five. The maximum value of aerosol density found by Curren et al., which occurred with the orifice $20 \mathrm{~mm}$ above the uranium oxide powder level, was $9 \times 10^{-6} \mathrm{~g} / \mathrm{cm}^{3}$. Using plutonium oxide powders in helium, Yesso et al. measured a maximum aerosol density of $5.0 \times 10^{-3} \mu \mathrm{g} / \mathrm{cm}^{3}$ (or $5.0 \times 10^{-9} \mathrm{~g} / \mathrm{cm}^{3}$ ). 


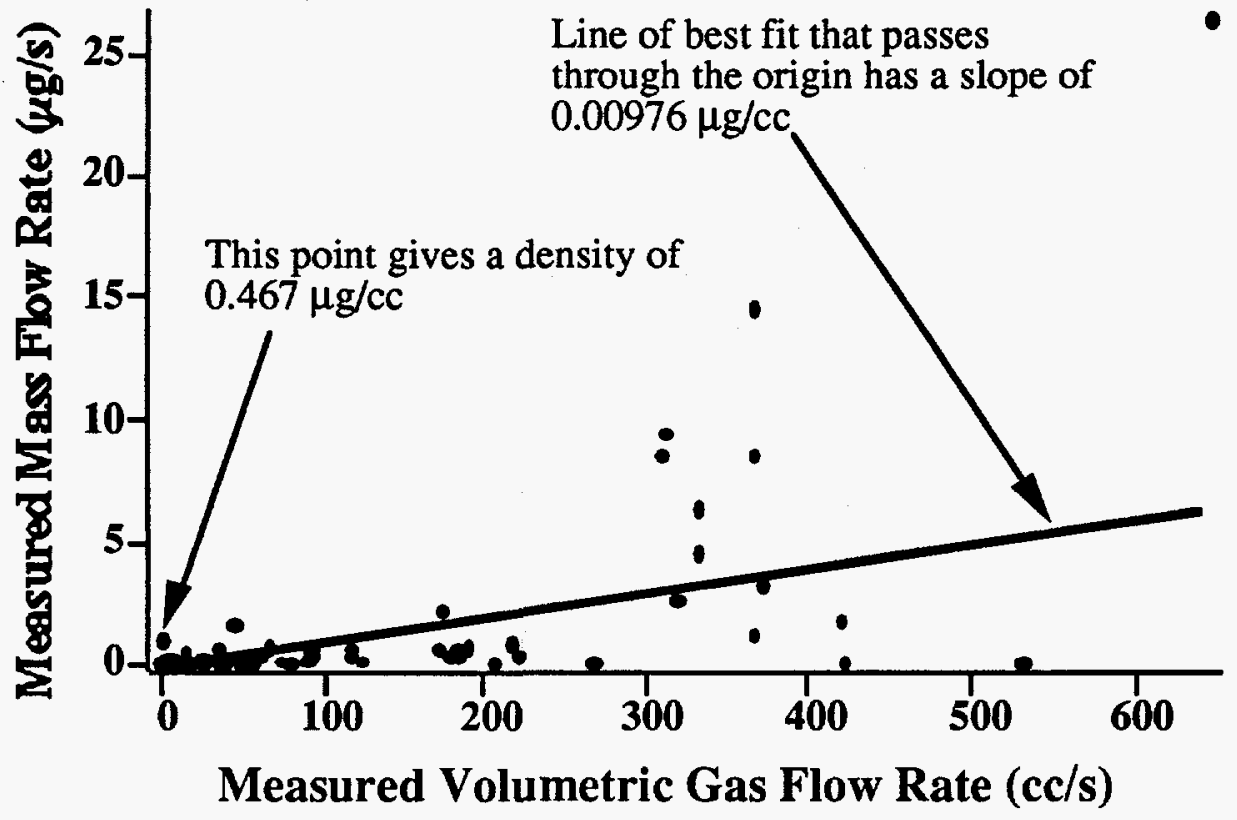

Figure 3-1. Measured volumetric flow rate versus measured mass flow rate from Schwendiman et al. for the flow of an aerosol of radioactive oxides through micro-capillaries. All the data are from experiments with the leak hole above the static powder level.

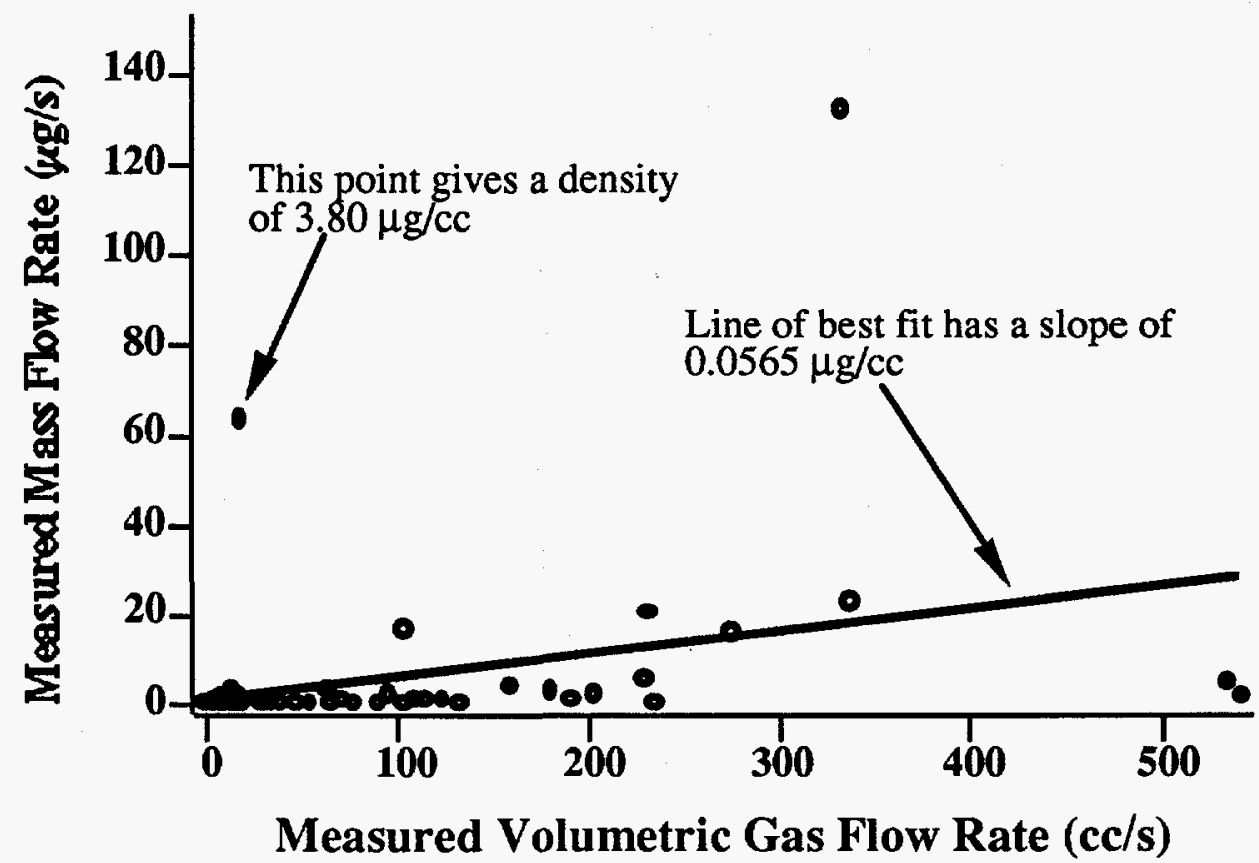

Figure 3-2. Measured volumetric flow rate versus measured mass flow rate from Schwendiman et al. for the flow of an aerosol of radioactive oxides through micro-capillaries. All data are from experiments with leak hole below the static powder level. 
Table 3-1 summarizes the maximum measured aerosol densities reported in the literature for aerosols made of radioactive oxides (or suitable surrogate powders) in gas (air or helium). The measured aerosol densities ranged from a low of $5.0 \times 10^{-9} \mathrm{~g} / \mathrm{cm}^{3}$ to a high of $9.0 \times 10^{-6} \mathrm{~g} / \mathrm{cm}^{3}$. Since $9 \times 10^{-6} \mathrm{~g} / \mathrm{cm}^{3}$ was the largest aerosol density measured, this is the bounding value used in calculations involving leakage from packages holding powdered radionuclides that contain Category I quantities of material. Other studies involving generation of aerosols (Kodas \& Sood 1987; Morton et al. 1992; Pratsinis et al. 1988; Sutter et al. 1981) have observed similar aerosol densities. Using sub-micronsized cerium oxide particles, Morton et al. (1992) measured aerosol densities within the range $8.6 \times 10^{-9}$ to $2.5 \times 10^{-7}$ $\mathrm{g} / \mathrm{cm}^{3}$. Using alumina powders with an average particle diameter of approximately $0.57 \mu \mathrm{m}$, Kodas and Sood measured a maximum total particle density on the order of
$10^{7}$ particles $/ \mathrm{cm}^{3}$, which corresponds to an aerosol density of $7.85 \times 10^{-6} \mathrm{~g} / \mathrm{cm}^{3}$ when the pure alumina density of 2.7 $\mathrm{g} / \mathrm{cm}^{3}$ is used.

Using simulation techniques, Pratsinis et al. have reported an alumina particle aerosol concentration of $10^{8}$ particles $/ \mathrm{cm}^{3}$. Sutter et al. reports that $S$ wain et al. found an aerosol density of $3.3 \times 10^{-8} \mathrm{~g} / \mathrm{cm}^{3}$ for nonnuclear sources, Castleman et al. measured a plutonium aerosol concentration of $7.1 \times 10^{-8} \mathrm{~g} / \mathrm{cm}^{3}$, and Mishima anticipates an upper concentration of $1.0 \times 10^{-7} \mathrm{~g} / \mathrm{cm}^{3}$ for quasi-stable, accident-generated, airborne concentrations of dry powders. The aerosol densities observed by these other groups fall within the range of results shown in Table 3-1 for aerosols of powdered radioactive oxides, and further support the supposition that $9 \times 10^{-6} \mathrm{~g} / \mathrm{cm}^{3}$ is a conservative bounding assessment for an estimation of aerosol mass density.

Table 3-1. Summary of Aerosol Densities Reported in the Literature

\begin{tabular}{|c|c|c|c|c|}
\hline Author(s) & $\begin{array}{l}\text { Experiment } \\
\text { Description }\end{array}$ & $\begin{array}{l}\text { Powdered } \\
\text { Compounds } \\
\text { Used }\end{array}$ & $\begin{array}{l}\text { Density from } \\
\text { "Line-of-Best-Fit" } \\
\left(\mathrm{g} / \mathrm{cm}^{3}\right)\end{array}$ & $\begin{array}{l}\text { Maximum } \\
\text { Measured } \\
\text { Density } \\
\left(\mathrm{g} / \mathrm{cm}^{\mathbf{3}}\right)\end{array}$ \\
\hline $\begin{array}{l}\text { Schwendiman } \\
\text { et al. }\end{array}$ & $\begin{array}{l}\text { flow path above the } \\
\text { static powder level }\end{array}$ & $\begin{array}{l}\mathrm{PuO}_{2} \& \text { depleted } \\
\mathrm{UO}_{2}\end{array}$ & $9.8 \times 10^{-9}$ & $4.7 \times 10^{-7}$ \\
\hline $\begin{array}{l}\text { Schwendiman } \\
\text { et al. }\end{array}$ & $\begin{array}{l}\text { flow path below the } \\
\text { static powder level }\end{array}$ & $\begin{array}{l}\mathrm{PuO}_{2} \& \text { depleted } \\
\mathrm{UO}_{2}\end{array}$ & $5.7 \times 10^{-8}$ & $3.8 \times 10^{-6}$ \\
\hline Curren et al. & $\begin{array}{l}\text { flow path above the } \\
\text { static powder level }\end{array}$ & depleted $\mathrm{UO}_{2}$ & data not given & $9.0 \times 10^{-6}$ \\
\hline Morton et al. & $\begin{array}{l}\text { measured with flow } \\
\text { studies }\end{array}$ & depleted $\mathrm{UO}_{2}$ & data not given & $2.5 \times 10^{-7}$ \\
\hline Kodas \& Sood & $\begin{array}{l}\text { measured particle conc. } \\
\text { optically }\end{array}$ & alumina & data not given & $7.85 \times 10^{-6}$ \\
\hline Yesso et al. & $\begin{array}{l}\text { measured with flow } \\
\text { studies }\end{array}$ & $\mathrm{PuO}_{2}$ & data not given & $5 \times 10^{-9}$ \\
\hline
\end{tabular}




\subsection{Characteristics of Packages that Transport Powdered Nuclear Materials}

There are currently 15 NRC-certified packages used primarily to transport powdered radionuclides. Figure 3-3 shows a plot of the temperatures and pressures for normal transport for these packages, and Figure 3-4 shows a plot of the temperatures and pressures for hypothetical accident conditions for these packages.

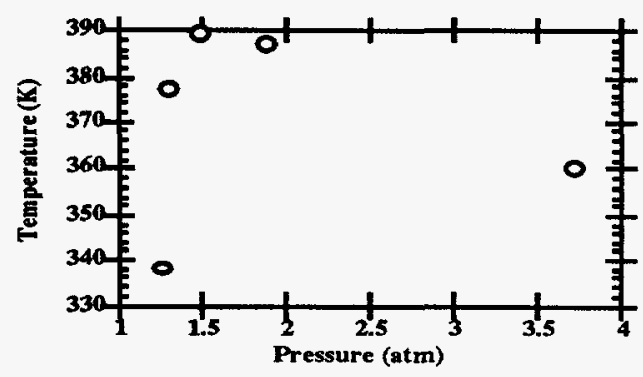

Figure 3-3. Temperatures and corresponding pressures for packages used to transport powdered radionuclides during normal transport.

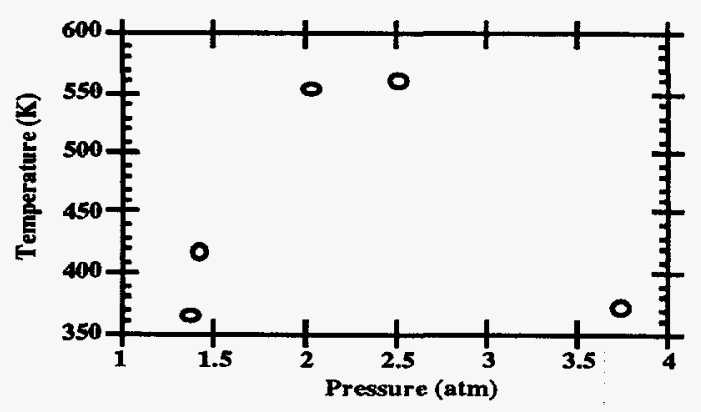

Figure 3-4. Temperatures and corresponding pressures for packages used to transport powdered radionuclides during hypothetical accident conditions.

\subsection{Acceptance Leakage Rates}

To calculate the acceptable leakage rates in units of $\mathrm{cm}^{3} / \mathrm{s}$ for normal transport conditions, Equation 2-2 in Section 2.1.1 is first used to calculate the acceptable release rate in units of $\mathrm{Ci} / \mathrm{s}$. This value is divided by the product of the specific activity (Ci/g) and the aerosol mass density. Similarly, for accident conditions, Equation 2-4 in Section 2.1.2 is used to obtain the release rate in units of $\mathrm{Ci} / \mathrm{s}$ and then this value is divided by the product of the specific activity $(\mathrm{Ci} / \mathrm{g})$ and the aerosol mass density $\left(\mathrm{g} / \mathrm{cm}^{3}\right)$ to obtain the allowable leakage rate in units of $\mathrm{cm}^{3} / \mathrm{s}$.

The amount of radioactivity in a transportation package can be classified into three main categories. A Category I quantity of material has greater than $3,000 \mathrm{~A}_{2}$ of activity, a Category II quantity of radioactive material has between $30 \mathrm{~A}_{2}$ and $3000 \mathrm{~A}_{2}$, and a Category III quantity of radioactive material has less than $30 \mathrm{~A}_{2}$ of activity. It is clear that packages transporting material with a relatively high activity (e.g., Category I) should require relatively more conservatism in the leakage rate acceptance criteria, as compared to packages transporting material with a relatively low amount of total activity (e.g., Category III). For packages used to transport Category I quantities of material, the aerosol density used was $9 \times 10^{-6} \mathrm{~g} / \mathrm{cm}^{3}$, which is a bounding value assessment. For packages used to transport Category III quantities of material, the aerosol density used was $5.7 \times 10^{-8} \mathrm{~g} / \mathrm{cm}^{3}$, which was obtained from the line-of-best-fit of the Schwendiman data for experiments with the leak path below the static powder level. The aerosol density used for packages that contain a Category II quantity of material is intermediate to the values used for the Category I and Category III packages and was $1 \times 10^{-6} \mathrm{~g} / \mathrm{cm}^{3}$. Table $3-2$ gives the calculated allowable leakage rates under normal transport and hypothetical accident conditions for these packages.

Using the allowable leakage rates given in Table 3-2 for a given contents Category and contents type, the corresponding leakage hole diameter is determined for each package using its maximum operational temperature and pressure. Then, using these diameters, the corresponding standard leakage rates are determined. The standard leakage rate is the flow of dry air in units of $\mathrm{std} \cdot \mathrm{cm}^{3} / \mathrm{s}$ at an upstream pressure of $1.0 \mathrm{~atm}$ when the downstream pressure is $0.01 \mathrm{~atm}$ and the temperature is $298 \mathrm{~K}$. For a given contents type, contents Category, and transportation conditions, the smallest standard leakage rate is taken as the acceptance leakage rate. This leak rate is a simplified containment criterion, that when satisfied, ensures that the package will not release more than the regulatory allowed amount of radionuclides. Table 3-3 gives the acceptance standard leakage rates for packages used to transport powdered radionuclides as a function of contents type and contents Category. 
Table 3-2. Allowable Leakage Rates Under Normal Transport and Hypothetical Accident Conditions for Packages Used to Transport Powdered Radionuclides

\begin{tabular}{|c|c|c|c|c|c|c|c|c|c|}
\hline \multirow[t]{2}{*}{$\begin{array}{l}\text { Package } \\
\text { Contents }\end{array}$} & \multicolumn{2}{|l|}{$\mathbf{A}_{2}$} & \multirow{2}{*}{\begin{tabular}{|l}
$\begin{array}{l}\text { Specific } \\
\text { Activity }\end{array}$ \\
(Ci/g)
\end{tabular}} & \multicolumn{3}{|c|}{$\begin{array}{l}\text { Normal Transport Conditions } \\
\text { Allowable Leakage Rate }\left(\mathrm{cm}^{3} / \mathrm{s}\right)\end{array}$} & \multicolumn{3}{|c|}{$\begin{array}{l}\text { Hypothetical Accident Conditions } \\
\text { Allowable Leakage Rate }\left(\mathrm{cm}^{3} / \mathrm{s}\right)\end{array}$} \\
\hline & (Ci) & (TBq) & & Cat. I & Cat. II & Cat. III & Cat. I & Cat. II & Cat. III \\
\hline${ }^{239} \mathrm{PuO}_{2}$ & $5.41 \times 10^{-3}$ & $2 \times 10^{-4}$ & $5.47 \times 10^{-2}$ & $3.05 \times 10^{-6}$ & $2.75 \times 10^{-5}$ & $4.82 \times 10^{-4}$ & $1.82 \times 10^{-2}$ & 0.164 & 2.87 \\
\hline $240 \mathrm{PuO}_{2}$ & $5.41 \times 10^{-3}$ & $2 \times 10^{-4}$ & 0.203 & $8.23 \times 10^{-7}$ & $7.41 \times 10^{-6}$ & $1.30 \times 10^{-4}$ & $4.90 \times 10^{-3}$ & $4.41 \times 10^{-2}$ & 0.773 \\
\hline${ }^{241} \mathrm{PuO}_{2}$ & 0.27 & 0.01 & 97.1 & $8.58 \times 10^{-8}$ & $7.72 \times 10^{-7}$ & $1.35 \times 10^{-5}$ & $5.11 \times 10^{-4}$ & $4.60 \times 10^{-3}$ & $8.07 \times 10^{-2}$ \\
\hline${ }^{233} \mathrm{UO}_{2}$ & 0.027 & 0.001 & $8.35 \times 10^{-3}$ & $9.98 \times 10^{-5}$ & $8.98 \times 10^{-4}$ & $1.58 \times 10^{-2}$ & 0.594 & 5.34 & 93.8 \\
\hline $\begin{array}{l}\mathrm{UO}_{2} \text { with } \\
95 \% \\
{ }^{235} \mathrm{UO}_{2}\end{array}$ & 0.027 & 0.001 & $8.01 \times 10^{-5}$ & $1.04 \times 10^{-2}$ & $9.36 \times 10^{-2}$ & 1.64 & 61.9 & 557 & $9.78 \times 10^{3}$ \\
\hline $\begin{array}{l}\mathrm{UO}_{2} \text { with } \\
93 \% \\
235 \mathrm{UO}_{2}\end{array}$ & 0.027 & 0.001 & $6.16 \times 10^{-5}$ & $1.35 \times 10^{-2}$ & 0.122 & 2.14 & 80.5 & 725 & $1.27 \times 10^{4}$ \\
\hline $\begin{array}{l}\mathrm{UO}_{2} \text { with } \\
90 \% \\
235 \mathrm{UO}_{2}\end{array}$ & 0.027 & 0.001 & $5.11 \times 10^{-5}$ & $1.63 \times 10^{-2}$ & 0.147 & 2.58 & 97.2 & 874 & $1.53 \times 10^{4}$ \\
\hline $\begin{array}{l}\mathrm{UO}_{2} \text { with } \\
50 \% \\
235 \mathrm{UO}_{2}\end{array}$ & 0.027 & 0.001 & $2.20 \times 10^{-5}$ & $3.79 \times 10^{-2}$ & 0.341 & 5.98 & 225 & $2.03 \times 10^{3}$ & $3.56 \times 10^{4}$ \\
\hline $\begin{array}{l}\mathrm{UO}_{2} \text { with } \\
35 \% \\
{ }^{235} \mathrm{UO}_{2}\end{array}$ & 0.027 & 0.001 & $1.76 \times 10^{-5}$ & $4.73 \times 10^{-2}$ & 0.426 & 7.48 & 282 & $2.54 \times 10^{3}$ & $4.45 \times 10^{4}$ \\
\hline $\begin{array}{l}\mathrm{UO}_{2} \text { with } \\
20 \% \\
235 \mathrm{UO}_{2}\end{array}$ & 0.027 & 0.001 & $8.80 \times 10^{-6}$ & $9.47 \times 10^{-2}$ & 0.852 & 15.0 & 564 & $5.07 \times 10^{3}$ & $8.90 \times 10^{4}$ \\
\hline $\begin{array}{l}\mathrm{UO}_{2} \text { with } \\
10 \% \\
{ }^{235} \mathrm{UO}_{2}\end{array}$ & 0.027 & 0.001 & $4.22 \times 10^{-6}$ & 0.197 & 1.78 & 31.2 & $1.18 \times 10^{3}$ & $1.06 \times 10^{4}$ & $1.86 \times 10^{5}$ \\
\hline $\begin{array}{l}\mathrm{UO}_{2} \text { with } \\
\leq 5 \% \\
235 \mathrm{UO}_{2}\end{array}$ & unlim. & unlim. & $\leq 2.38 \times 10^{-6}$ & unlim. & unlim. & unlim. & unlim. & unlim. & unlim. \\
\hline${ }^{233} U$ & 0.027 & 0.001 & $9.50 \times 10^{-3}$ & $8.77 \times 10^{-5}$ & $7.89 \times 10^{-4}$ & $1.39 \times 10^{-2}$ & 0.522 & 4.70 & 82.4 \\
\hline
\end{tabular}


Table 3-2. Allowable Leakage Rates Under Normal Transport and Hypothetical Accident Conditions for Packages Used to Transport Powdered Radionuclides, continued

\begin{tabular}{|c|c|c|c|c|c|c|c|c|c|}
\hline \multirow[t]{2}{*}{$\begin{array}{l}\text { Package } \\
\text { Contents }\end{array}$} & \multicolumn{2}{|l|}{$\mathbf{A}_{2}$} & \multirow{2}{*}{\begin{tabular}{|l}
$\begin{array}{l}\text { Specific } \\
\text { Activity }\end{array}$ \\
$(\mathrm{Ci} / \mathrm{g})$ \\
\end{tabular}} & \multicolumn{3}{|c|}{$\begin{array}{l}\text { Normal Transport Conditions } \\
\text { Allowable Leakage Rate }\left(\mathrm{cm}^{3} / \mathrm{s}\right)\end{array}$} & \multicolumn{3}{|c|}{$\begin{array}{l}\text { Hypothetical Accident Conditions } \\
\text { Allowable Leakage Rate }\left(\mathrm{cm}^{3} / \mathrm{s}\right)\end{array}$} \\
\hline & (Ci) & (TBq) & & Cat. I & Cat. II & Cat. III & Cat. I & Cat. II & Cat. III \\
\hline $\begin{array}{l}\text { U with } 95 \% \\
235_{U}\end{array}$ & 0.027 & 0.001 & $9.10 \times 10^{-5}$ & $9.16 \times 10^{-3}$ & $8.24 \times 10^{-2}$ & 1.45 & 54.5 & 491 & $8.61 \times 10^{3}$ \\
\hline $\begin{array}{l}\text { U with } 93 \% \\
235_{U}\end{array}$ & 0.027 & 0.001 & $7.00 \times 10^{-5}$ & $1.19 \times 10^{-2}$ & 0.107 & 1.88 & $\begin{array}{l}7 \\
0.9\end{array}$ & 638 & $1.12 \times 10^{4}$ \\
\hline $\begin{array}{l}\text { U with } 90 \% \\
235_{U}\end{array}$ & 0.027 & 0.001 & $5.80 \times 10^{-5}$ & $1.44 \times 10^{-2}$ & 0.129 & 2.27 & 85.5 & 770 & $1.35 \times 10^{4}$ \\
\hline $\begin{array}{l}\text { U with } 50 \% \\
235 \mathrm{U}\end{array}$ & 0.027 & 0.001 & $2.50 \times 10^{-5}$ & $3.33 \times 10^{-2}$ & 0.300 & 5.26 & 198 & $1.79 \times 10^{3}$ & $3.13 \times 10^{4}$ \\
\hline $\begin{array}{l}\text { U with } 35 \% \\
235_{U}\end{array}$ & 0.027 & 0.001 & $2.00 \times 10^{-5}$ & $4.17 \times 10^{-2}$ & 0.375 & 6.58 & 248 & $2.23 \times 10^{3}$ & $3.92 \times 10^{4}$ \\
\hline $\begin{array}{l}\text { U with } 20 \% \\
235_{U}\end{array}$ & 0.027 & 0.001 & $1.00 \times 10^{-5}$ & $8.33 \times 10^{-2}$ & 0.750 & 13.2 & 496 & $4.46 \times 10^{3}$ & $7.83 \times 10^{4}$ \\
\hline $\begin{array}{l}\text { U with } 10 \% \\
235_{U}\end{array}$ & 0.027 & 0.001 & $4.80 \times 10^{-6}$ & 0.174 & 1.56 & 27.4 & $1.03 \times 10^{3}$ & $9.30 \times 10^{3}$ & $1.63 \times 10^{5}$ \\
\hline $\begin{array}{l}\text { U with } \leq 5 \% \\
235_{U}\end{array}$ & unlim. & u & $\leq 2.70 \times 10^{-6}$ & unlim. & unlim. & unlim. & unlim. & unlim. & unlim. \\
\hline
\end{tabular}


Table 3-3. Acceptance Standard Leakage Rates for Packages Used to Transport Powdered Radionuclides

\begin{tabular}{|c|c|c|c|c|c|c|}
\hline \multirow[t]{2}{*}{ Package Contents } & \multicolumn{3}{|c|}{$\begin{array}{l}\text { Acceptance Standard Leakage Rate } \\
\text { [corresponding to normal transport } \\
\text { conditions requirements] }\left(\mathrm{std} \cdot \mathrm{cm}^{3} / \mathrm{s}\right)\end{array}$} & \multicolumn{3}{|c|}{$\begin{array}{l}\text { Acceptance Standard Leakage Rate } \\
\text { [corresponding to hypothetical accident } \\
\left.\text { conditions requirements] (std } \mathrm{cm}^{3} / \mathrm{s}\right)\end{array}$} \\
\hline & Category I & Category II & Category III & Category I & Category II & Category III \\
\hline${ }^{239} \mathrm{PuO}_{2}$ & $3.02 \times 10^{-6}$ & $3.01 \times 10^{-5}$ & $5.81 \times 10^{-4}$ & $1.77 \times 10^{-2}$ & 0.164 & 2.94 \\
\hline $240 \mathrm{PuO}_{2}$ & $7.64 \times 10^{-7}$ & $7.66 \times 10^{-6}$ & $1.51 \times 10^{-4}$ & $4.63 \times 10^{-3}$ & $4.34 \times 10^{-2}$ & 0.786 \\
\hline${ }^{241} \mathrm{PuO}_{2}$ & leak tight $*$ & $7.15 \times 10^{-7}$ & $1.43 \times 10^{-5}$ & $4.51 \times 10^{-4}$ & $4.34 \times 10^{-3}$ & $8.02 \times 10^{-2}$ \\
\hline${ }^{233} \mathrm{UO} 2$ & $1.15 \times 10^{-4}$ & $1.10 \times 10^{-3}$ & $2.04 \times 10^{-2}$ & 0.603 & 5.50 & 97.5 \\
\hline $\mathrm{UO}_{2}$ with $95 \%{ }^{235} \mathrm{UO}_{2}$ & $1.33 \times 10^{-2}$ & 0.123 & 2.19 & 64.3 & $5.81 \times 10^{2}$ & $1.02 \times 10^{4}$ \\
\hline $\mathrm{UO}_{2}$ with $93 \%{ }^{235} \mathrm{UO}_{2}$ & $1.74 \times 10^{-2}$ & 0.161 & 2.87 & 83.7 & $7.57 \times 10^{2}$ & $1.33 \times 10^{4}$ \\
\hline $\mathrm{UO}_{2}$ with $90 \%{ }^{235} \mathrm{UO}_{2}$ & $2.10 \times 10^{-2}$ & 0.194 & 3.46 & $1.02 \times 10^{2}$ & $9.13 \times 10^{2}$ & $1.60 \times 10^{4}$ \\
\hline $\mathrm{UO}_{2}$ with $50 \%{ }^{235} \mathrm{UO}_{2}$ & $4.94 \times 10^{-2}$ & 0.453 & 8.04 & $2.34 \times 10^{2}$ & $2.12 \times 10^{3}$ & $3.73 \times 10^{4}$ \\
\hline $\mathrm{UO}_{2}$ with $35 \%{ }^{235} \mathrm{UO}_{2}$ & $6.18 \times 10^{-2}$ & 0.566 & 10.1 & $2.94 \times 10^{2}$ & $2.66 \times 10^{3}$ & $4.66 \times 10^{4}$ \\
\hline $\mathrm{UO}_{2}$ with $20 \%{ }^{235} \mathrm{UO}_{2}$ & 0.12 & 1.14 & 20.2 & $5.88 \times 10^{2}$ & $5.67 \times 10^{3}$ & $9.33 \times 10^{4}$ \\
\hline $\mathrm{UO}_{2}$ with $10 \%{ }^{235} \mathrm{UO}_{2}$ & 0.26 & 2.38 & 42.2 & $1.23 \times 10^{3}$ & $3.46 \times 10^{4}$ & $1.95 \times 10^{5}$ \\
\hline $\mathrm{UO}_{2}$ with $\leq 5 \%{ }^{235} \mathrm{UO}_{2}$ & unlimited ${ }^{* *}$ & unlimited & unlimited & unlimited & unlimited & unlimited \\
\hline${ }^{233} \mathrm{U}$ & $1.00 \times 10^{-4}$ & $9.63 \times 10^{-4}$ & $1.79 \times 10^{-2}$ & 0.529 & 4.83 & 85.7 \\
\hline U with $95 \% 235_{U}$ & $1.17 \times 10^{-2}$ & 0.108 & 1.94 & 56.6 & $5.12 \times 10^{2}$ & $9.01 \times 10^{3}$ \\
\hline $\mathrm{U}$ with $93 \%{ }^{235} \mathrm{U}$ & $1.53 \times 10^{-2}$ & 0.141 & 2.52 & 73.7 & $6.66 \times 10^{2}$ & $1.17 \times 10^{4}$ \\
\hline $\mathrm{U}$ with $90 \% 235 \mathrm{U}$ & $1.85 \times 10^{-2}$ & 0.170 & 3.04 & 88.9 & $8.04 \times 10^{2}$ & $1.41 \times 10^{4}$ \\
\hline $\mathrm{U}$ with $50 \% 235_{U}$ & $4.33 \times 10^{-2}$ & 0.398 & 7.07 & $2.06 \times 10^{2}$ & $1.87 \times 10^{3}$ & $3.28 \times 10^{4}$ \\
\hline $\mathrm{U}$ with $35 \% 235 \mathrm{U}$ & $5.44 \times 10^{-2}$ & 0.498 & 8.85 & $2.58 \times 10^{2}$ & $2.33 \times 10^{3}$ & $4.11 \times 10^{4}$ \\
\hline$U$ with $20 \% 235_{U}$ & 0.109 & 1.00 & 17.8 & $5.17 \times 10^{2}$ & $4.66 \times 10^{3}$ & $8.21 \times 10^{4}$ \\
\hline $\mathrm{U}$ with $10 \% 235_{\mathrm{U}}$ & 0.230 & 2.09 & 37.0 & $1.07 \times 10^{3}$ & $9.73 \times 10^{3}$ & $1.71 \times 10^{5}$ \\
\hline $\mathrm{U}$ with $\leq 5 \%{ }^{235} \mathrm{U}$ & unlimited & unlimited & unlimited & unlimited & unlimited & unlimited \\
\hline
\end{tabular}

* leak tight requires that the package pass a standard leak test with a volumetric flow rate of $1 \times 10^{-7} \mathrm{std} \cdot \mathrm{cm}^{3} / \mathrm{s}$ or less
** since the $A_{2}$ is unlimited, the allowable leakage rate at normal transport conditions, the allowable leakage rate at hypothetical accident conditions, and the standard leakage rate are all unlimited 



\section{Contents: Solid Byproduct or Special Nuclear Materials}

In this section, simple methods for determining the acceptance standard leakage rates for packages designed to transport solid radioactive materials are developed. These packages may contain dispersible solids that have a homogeneous radioactive distribution or non-dispersible solids that have releasable surface contamination.

\subsection{Measured Concentration in Leakage Path}

Dispersible solids and non-dispersible solids are considered separately when determining the corresponding source term of releasable material inside the containment vessel. Care must be exercised when determining which type of solid is being transported. Dispersible solids are materials that may crumble or fracture as a result of transportation and/or loading-induced forces and produce a powder aerosol in the containment vessel fill gas. Non-dispersible solids are structurally robust, will maintain their form when subject to transportation and/or loading-related forces, and contribute to the source term by aerosolization (spallation) of surface contamination into the containment vessel fill gas to form a releasable aerosol.

\subsubsection{Source Term for Dispersible Radioactive Solids}

Dispersible solid materials will tend to fracture and crumble due to handling, vibration, or accident conditions. These conditions will tend to cause the radioactive solid material inside the containment vessel to produce a powder aerosol. The source term concentration $\left(\mathrm{Ci} / \mathrm{cm}^{3}\right)$ can be expressed as the product of the aerosol mass density $\left(\mathrm{g} / \mathrm{cm}^{3}\right)$ and the specific activity of the dispersible solid (Ci/g). Based on a literature search of studies concerning generation of powder aerosols, it was found that a reasonable bounding value for the mass density of a powder aerosol is $9 \times 10^{-6} \mathrm{~g} / \mathrm{cm}^{3}$. In the analysis of the allowable leakage rates, a mass density of $9 \times 10^{-6} \mathrm{~g} / \mathrm{cm}^{3}$ was used to calculate the releasable source term concentration for Category I quantities of radioactive material; an aerosol mass density of $1 \times 10^{-6} \mathrm{~g} / \mathrm{cm}^{3}$ was used for Category II quantities of radioactive material; and an aerosol mass density of $5.7 \times 10^{-8} \mathrm{~g} / \mathrm{cm}^{3}$ was used for Category III quantities of radioactive material.

\subsubsection{Source Term for Non-Dispersible Solids With Radioactive Surface Contamination}

Structurally robust solids will not disperse as a result of transportation-related forces. For non-dispersible solids, no fines made of the bulk material should be present inside the package. Fines are characterized as particles with diameters less than about $100 \mu \mathrm{m}$. The releasable material for these packages is the surface contamination on the solid contents that can spall-off and become airborne inside the package. Similar to the treatment of crud on the surface of irradiated nuclear fuel rods, it is assumed that (1) under normal transport conditions, $15 \%$ of the surface contamination is airborne inside the package, and (2) under hypothetical accident conditions, $100 \%$ of the surface contamination is airborne in the package. As a result of the variability of surface contamination that may be present on solids, determination of this term requires experimental measurements (e.g., swipe tests). For normal transport conditions, the releasable activity is a product of the average surface contamination concentration $\left(\mathrm{Ci} / \mathrm{cm}^{2}\right)$, the total surface area $\left(\mathrm{cm}^{2}\right)$, and the factor 0.15 . For hypothetical accident conditions, the releasable activity is a product of the average surface contamination $\left(\mathrm{Ci} / \mathrm{cm}^{2}\right)$ and the total surface area $\left(\mathrm{cm}^{2}\right)$. The activity concentration of the source term is obtained by dividing the total releasable activity (Ci) by the void volume inside the containment vessel $\left(\mathrm{cm}^{3}\right)$.

\subsection{Characteristics of Packages that Transport Solid Byproduct or Special Nuclear Materials}

If the radioactive contents provides no appreciable heat load and the package is loaded at a pressure of one atmosphere, the maximum normal operating temperature is estimated as $150^{\circ} \mathrm{F}\left(65.5^{\circ} \mathrm{C}\right)$. As a conservative approach, the maximum normal operating pressure is estimated as 1.2 atmospheres.

During the hypothetical accident conditions fire test, the contents should not be above $1400^{\circ} \mathrm{F}\left(760^{\circ} \mathrm{C}\right)$. Therefore, it is conservative to assume that the maximum containment vessel pressure during the hypothetical accident conditions is 3.5 atmospheres.

\subsection{Calculation of Acceptance Leakage Rates}

\subsubsection{Allowable Standard Leak Rate for Containers Designed to Transport Dispersible Radioactive Solids}

Under normal transport conditions, the allowable volumetric leakage rate is: 
Equation 4-1

$$
\mathrm{L}_{\mathrm{N}}=\frac{\mathrm{R}_{\mathrm{N}}}{\mathrm{C}_{\mathrm{N}}}=\frac{\mathrm{R}_{\mathrm{N}}}{\mathrm{S}_{\mathrm{A}} \rho}=\frac{2.78 \times 10^{-10} \mathrm{~A}_{2} / \mathrm{s}}{\mathrm{S}_{\mathrm{A}} \rho}
$$

where:

$\mathrm{L}_{\mathrm{N}}$ is the allowable leakage rate at normal transport conditions $\left[\mathrm{cm}^{3} / \mathrm{s}\right]$,

$\mathrm{C}_{\mathrm{N}}$ is the activity concentration of the releasable material at normal transport conditions $\left[\mathrm{Ci} / \mathrm{cm}^{3}\right]$,

$R_{N}$ is the allowable release rate at normal transport conditions $[\mathrm{Ci} / \mathrm{s}]$,

$\mathrm{S}_{\mathrm{A}}$ is the specific activity of the releasable material [Ci/g], and

$\rho \quad$ is the mass density of the powder aerosol $\left[\mathrm{g} / \mathrm{cm}^{3}\right]$.

The allowable leakage rate in Equation 4-1 is at the upstream temperature and pressure. After determining the allowable leakage rate under normal transport conditions with Equation 4-1, the corresponding leak hole diameter is determined by equating Equation 4-1 to the equation for continuum and molecular flow at the upstream temperature and pressure and solving for the diameter. Then, using this leak hole diameter, the corresponding standard leak rate can be determined.

An analogous procedure is used to determine the standard leakage rate that corresponds to the hypothetical accident conditions. Under hypothetical accident conditions, the allowable volumetric leakage rate is:

\section{Equation 4-2}

$L_{A}=\frac{R_{A}}{C_{A}}=\frac{1.653 \times 10^{-6} A_{2} / s}{S_{A} \rho}$

where:

$\mathrm{L}_{\mathrm{A}}$ is the allowable volumetric leakage rate at hypothetical accident conditions $\left[\mathrm{cm}^{3} / \mathrm{s}\right]$,

$\mathbf{R}_{\mathbf{A}}$ is the allowable release rate at hypothetical accident conditions $[\mathrm{Ci} / \mathrm{s}]$,

$\mathrm{C}_{\mathrm{A}}$ is the activity concentration of the releasable material at hypothetical accident conditions $\left[\mathrm{Ci} / \mathrm{cm}^{3}\right]$,

$S_{A}$ is the specific activity of the releasable material [Ci/g], and

$\rho \quad$ is the density of the powder aerosol $\left[\mathrm{g} / \mathrm{cm}^{3}\right]$.
Using the aerosol mass densities, the allowable volumetric leakage rates at normal and hypothetical accident conditions can be calculated as a function of the ratio $\mathrm{A}_{2} / \mathrm{S}_{\mathrm{A}}$. The allowable volumetric leakage rates for dispersible solids are given in Table 4-1.

Using the allowable leakage rates given in Table 4-1 along with a constitutive equation, representative values of the corresponding acceptance standard leakage rates were calculated. Examples of these acceptance standard leakage rates for packages designed to transport dispersible solids are given in Table 4-2 as a function of the ratio $A_{2} / S_{A}$.

\subsubsection{Allowable Standard Leakage Rate for Containers Designed to Transport Non- Dispersible Solids with Radioactive Surface Contamination}

For transportation packages holding non-dispersible radioactive solids, the releasable material consists of fine particulates that spall-off the surfaces of the solids to create a powder aerosol inside the containment vessel. If a leak develops in the containment vessel, this suspended particulate material would be entrained in the leaking gas and result in a radioactive release to the environment. The activity concentration of this powder aerosol can be described as:

\section{Equation 4-3}

$$
C_{i}=\frac{S_{A S} A_{S C} f_{A}}{V},
$$

where:

$\mathrm{C}_{\mathrm{i}}$ is the activity concentration of the powder aerosol $\left[\mathrm{Ci} / \mathrm{cm}^{3}\right]$, with $\mathrm{i}=\mathrm{N}$ for normal transport conditions and $\mathrm{i}=\mathrm{A}$ for hypothetical accident conditions,

$S_{A S}$ is the total surface area of the surface-contaminated solids $\left[\mathrm{cm}^{2}\right]$,

ASC is the activity surface density of the surfacecontaminated solids [Ci/ $\mathrm{cm}^{2}$,

$\mathbf{f}_{A}$ is the activity-fraction of the surface contamination that spalls-off the surface-contaminated solids during transportation, where $\mathrm{f}_{A}=\mathbf{0 . 1 5}$ for normal transport conditions and $f_{A}=1.0$ for hypothetical accident conditions, and

$\mathrm{V}$ is the containment vessel void volume $\left[\mathrm{cm}^{3}\right]$.

Dividing the allowable release rate by the activity concentration of the source term given by Equation 4-3 gives the allowable leakage rate under transport conditions. 
For normal transport conditions, the allowable volumetric leakage rate is:

\section{Equation 4-4}

$$
\mathrm{L}_{\mathrm{N}}=\left(1.85 \times 10^{-9} \frac{1}{\mathrm{~s}}\right) \frac{\mathrm{A}_{2} \mathrm{~V}}{\mathrm{~S}_{\mathrm{AS}} \mathrm{A}_{\mathrm{SC}}}
$$

Similarly, for hypothetical accident conditions the allowable volumetric leakage rate is:

\section{Equation 4-5}

$$
\mathrm{L}_{\mathrm{A}}=\left(1.65 \times 10^{-6} \frac{1}{\mathrm{~s}}\right) \frac{\mathrm{A}_{2} \mathrm{~V}}{\mathrm{~S}_{\mathrm{AS}} \mathrm{A}_{\mathrm{SC}}}
$$

\section{Example: Surface-Contaminated Steel Rods}

When surface-contaminated steel rods are transported, the releasable material is the surface contamination that spallsoff the contaminated material and produces a powder aerosol. Consider transporting 100 steel rods that are $50 \mathrm{~cm}$ long and have a diameter of $1.0 \mathrm{~cm}$. These rods are held in a containment vessel that, when filled, has a free void volume, $\mathrm{V}$, of $10^{4} \mathrm{~cm}^{3}$. From experimental measurements, it was found that the rods have an average surface contamination, ASC, of $9 \mathrm{Ci} / \mathrm{cm}^{2}$. Since cobalt -60 is the major component of the surface contamination, an $\mathrm{A}_{2}$ of $10.8 \mathrm{Ci}$ is used for calculational purposes. Using the rod dimensions given above, the total rod surface area, $S_{A S}$, is calculated as $3927 \mathrm{~cm}^{2}$.

Using Equation 4-4, under normal transport conditions the allowable leakage rate, $\mathrm{L}_{\mathrm{N}}$, is calculated as $5.65 \times 10^{-9}$ $\mathrm{cm}^{3} / \mathrm{s}$. At normal transport conditions $\left(\mathrm{P}_{\mathrm{u}}=1.2 \mathrm{~atm}\right.$, $\mathrm{T}=338.5 \mathrm{~K}, \mathrm{a}=1.0 \mathrm{~cm}, \mathrm{He}$ gas), the leak hole diameter that corresponds to the allowable leakage rate is $8.9 \times 10^{-5} \mathrm{~cm}$. The standard leakage rate that corresponds to this leak hole diameter is then $1.2 \times 10^{-8} \mathrm{std} \cdot \mathrm{cm}^{3} / \mathrm{s}$, which defaults to the "leak tight" criterion.

Using Equation 4-5, under hypothetical accident conditions the allowable leakage rate, $\mathrm{L}_{\mathrm{A}}$, is calculated as $5.04 \times 10^{-6}$ $\mathrm{cm}^{3} / \mathrm{s}$. Under the hypothetical accident conditions $\left(\mathrm{P}_{\mathrm{u}}=3.5\right.$ $\mathrm{atm}, \mathrm{T}=1033 \mathrm{~K}$ ), the leak hole diameter that corresponds to the allowable leakage rate is approximately $4.0 \mu \mathrm{m}$. The standard leakage rate that corresponds to this leak hole diameter is approximately $2.4 \times 10^{-6} \mathrm{std} \cdot \mathrm{cm}^{3} / \mathrm{s}$. 
Table 4-1. Allowable Volumetric Leakage Rates at Normal and Hypothetical Accident Conditions for Dispersible Solids as a Function of $\mathbf{A 2}_{2} / \mathbf{S}_{\mathbf{A}}$

\begin{tabular}{|c|c|c|c|c|c|c|}
\hline \multirow[b]{2}{*}{$\mathbf{A}_{2} / \mathbf{S}_{\mathbf{A}}$} & \multicolumn{3}{|c|}{$\begin{array}{l}\text { Allowable Leakage Rate at Normal } \\
\text { Transport Conditions }\left(\mathrm{cm}^{3} / \mathrm{s}\right)\end{array}$} & \multicolumn{3}{|c|}{$\begin{array}{l}\text { Allowable Leakage Rate at Hypothetica } \\
\text { Accident Conditions }\left(\mathrm{cm}^{3} / \mathrm{s}\right)\end{array}$} \\
\hline & Cat. I & Cat. II & Cat. III & Cat. I & Cat. II & Cat. III \\
\hline$\geq 1 \times 10^{-8}$ & $3.09 \times 10^{-13}$ & $2.78 \times 10^{-12}$ & $4.88 \times 10^{-11}$ & $1.84 \times 10^{-9}$ & $1.65 \times 10^{-8}$ & $2.90 \times 10^{-7}$ \\
\hline$\geq 1 \times 10^{-7}$ & $3.09 \times 10^{-12}$ & $2.78 \times 10^{-11}$ & $4.88 \times 10^{-10}$ & $1.84 \times 10^{-8}$ & $1.65 \times 10^{-7}$ & $2.90 \times 10^{-6}$ \\
\hline$\geq 1 \times 10^{-6}$ & $3.09 \times 10^{-11}$ & $2.78 \times 10^{-10}$ & $4.88 \times 10^{-9}$ & $1.84 \times 10^{-7}$ & $1.65 \times 10^{-6}$ & $2.90 \times 10^{-5}$ \\
\hline$\geq 1 \times 10^{-5}$ & $3.09 \times 10^{-10}$ & $2.78 \times 10^{-9}$ & $4.88 \times 10^{-8}$ & $1.84 \times 10^{-6}$ & $1.65 \times 10^{-5}$ & $2.90 \times 10^{-4}$ \\
\hline$\geq 1 \times 10^{-4}$ & $3.09 \times 10^{-9}$ & $2.78 \times 10^{-8}$ & $4.88 \times 10^{-7}$ & $1.84 \times 10^{-5}$ & $1.65 \times 10^{-4}$ & $2.90 \times 10^{-3}$ \\
\hline$\geq 1 \times 10^{-3}$ & $3.09 \times 10^{-8}$ & $2.78 \times 10^{-7}$ & $4.88 \times 10^{-6}$ & $1.84 \times 10^{-4}$ & $1.65 \times 10^{-3}$ & $2.90 \times 10^{-2}$ \\
\hline$\geq 1 \times 10^{-2}$ & $3.09 \times 10^{-7}$ & $2.78 \times 10^{-6}$ & $4.88 \times 10^{-5}$ & $1.84 \times 10^{-3}$ & $1.65 \times 10^{-2}$ & $2.90 \times 10^{-1}$ \\
\hline$\geq 1 \times 10^{-1}$ & $3.09 \times 10^{-6}$ & $2.78 \times 10^{-5}$ & $4.88 \times 10^{-4}$ & $1.84 \times 10^{-2}$ & $1.65 \times 10^{-1}$ & 2.90 \\
\hline$\geq 1$ & $3.09 \times 10^{-5}$ & $2.78 \times 10^{-4}$ & $4.88 \times 10^{-3}$ & $1.84 \times 10^{-1}$ & 1.65 & $2.90 \times 10^{1}$ \\
\hline$\geq 1 \times 10^{1}$ & $3.09 \times 10^{-4}$ & $2.78 \times 10^{-3}$ & $4.88 \times 10^{-2}$ & 1.84 & $1.65 \times 10^{1}$ & $2.90 \times 10^{2}$ \\
\hline$\geq 1 \times 10^{2}$ & $3.09 \times 10^{-3}$ & $2.78 \times 10^{-2}$ & $4.88 \times 10^{-1}$ & $1.84 \times 10^{1}$ & $1.65 \times 10^{2}$ & $2.90 \times 10^{3}$ \\
\hline$\geq 1 \times 10^{3}$ & $3.09 \times 10^{-2}$ & $2.78 \times 10^{-1}$ & 4.88 & $1.84 \times 10^{2}$ & $1.65 \times 10^{3}$ & $2.90 \times 10^{4}$ \\
\hline$\geq 1 \times 10^{4}$ & $3.09 \times 10^{-1}$ & 2.78 & $4.88 \times 10^{1}$ & $1.84 \times 10^{3}$ & $1.65 \times 10^{4}$ & $2.90 \times 10^{5}$ \\
\hline$\geq 1 \times 10^{5}$ & 3.09 & $2.78 \times 10^{1}$ & $4.88 \times 10^{2}$ & $1.84 \times 10^{4}$ & $1.65 \times 10^{5}$ & $2.90 \times 10^{6}$ \\
\hline$\geq 1 \times 10^{6}$ & $3.09 \times 10^{1}$ & $2.78 \times 10^{2}$ & $4.88 \times 10^{3}$ & $1.84 \times 10^{5}$ & $1.65 \times 10^{6}$ & $2.90 \times 10^{7}$ \\
\hline$\geq 1 \times 10^{7}$ & $3.09 \times 10^{2}$ & $2.78 \times 10^{3}$ & $4.88 \times 10^{4}$ & $1.84 \times 10^{6}$ & $1.65 \times 10^{7}$ & $2.90 \times 10^{8}$ \\
\hline
\end{tabular}


Table 4-2. Representative Acceptance Standard Leakage Rates for Packages Designed to Transport Dispersible Solids as a Function of the Ratio $A_{2} / S_{A}$

\begin{tabular}{|c|c|c|c|c|c|c|}
\hline \multirow[b]{2}{*}{$\mathbf{A}_{2} / \mathbf{S}_{\mathbf{A}}$} & \multicolumn{3}{|c|}{$\begin{array}{l}\text { Standard Leak Rate Criteria } \\
\text { corresponding to } \\
\text { normal transport conditions- } \\
\left(\mathbf{s t d} \cdot \mathrm{cm}^{3} / \mathrm{s}\right)\end{array}$} & \multicolumn{3}{|c|}{$\begin{array}{l}\text { Standard Leak Rate Criteria } \\
\text { corresponding to } \\
\text { hypothetical accident conditions- } \\
\text { (std } \cdot \mathrm{cm}^{3} / \mathrm{s} \text { ) }\end{array}$} \\
\hline & Cat. I & Cat. II & Cat. III & Cat. I & Cat. II & Cat. III \\
\hline$\geq 1 \times 10^{-8}$ & $*$ & $*$ & * & $*$ & $*$ & * \\
\hline$\geq 1 \times 10^{-7}$ & * & * & * & $*$ & $*$ & $8.33 \times 10^{-7}$ \\
\hline$\geq 1 \times 10^{-6}$ & * & * & * & * & $6.48 \times 10^{-7}$ & $9.66 \times 10^{-6}$ \\
\hline$\geq 1 \times 10^{-5}$ & * & * & $1.22 \times 10^{-7}$ & $7.27 \times 10^{-7}$ & $7.52 \times 10^{-6}$ & $1.10 \times 10^{-4}$ \\
\hline$\geq 1 \times 10^{-4}$ & $*$ & * & $1.34 \times 10^{-6}$ & $8.44 \times 10^{-6}$ & $8.57 \times 10^{-5}$ & $1.21 \times 10^{-3}$ \\
\hline$\geq 1 \times 10^{-3}$ & $*$ & $7.45 \times 10^{-7}$ & $1.47 \times 10^{-5}$ & $9.61 \times 10^{-5}$ & $9.45 \times 10^{-4}$ & $1.28 \times 10^{-2}$ \\
\hline$\geq 1 \times 10^{-2}$ & $8.32 \times 10^{-7}$ & $8.12 \times 10^{-6}$ & $1.58 \times 10^{-4}$ & $1.06 \times 10^{-3}$ & $1.01 \times 10^{-2}$ & $1.33 \times 10^{-1}$ \\
\hline$\geq 1 \times 10^{-1}$ & $9.14 \times 10^{-6}$ & $8.86 \times 10^{-5}$ & $1.66 \times 10^{-3}$ & $1.13 \times 10^{-2}$ & $1.05 \times 10^{-1}$ & 1.36 \\
\hline$\geq 1$ & $9.88 \times 10^{-5}$ & $9.37 \times 10^{-4}$ & $1.72 \times 10^{-2}$ & $1.17 \times 10^{-1}$ & 1.07 & $1.38 \times 10^{1}$ \\
\hline$\geq 1 \times 10^{1}$ & $1.04 \times 10^{-3}$ & $9.72 \times 10^{-3}$ & $1.75 \times 10^{-1}$ & 1.20 & $1.09 \times 10^{1}$ & $1.39 \times 10^{2}$ \\
\hline$\geq 1 \times 10^{2}$ & $1.08 \times 10^{-2}$ & $9.94 \times 10^{-2}$ & 1.77 & $1.22 \times 10^{1}$ & $1.10 \times 10^{2}$ & $* *$ \\
\hline$\geq 1 \times 10^{3}$ & $1.10 \times 10^{-1}$ & 1.01 & $1.78 \times 10^{1}$ & $1.22 \times 10^{2}$ & $* *$ & $* *$ \\
\hline$\geq 1 \times 10^{4}$ & 1.11 & $1.01 \times 10^{1}$ & $1.79 \times 10^{2}$ & $* *$ & $* *$ & $* *$ \\
\hline$\geq 1 \times 10^{5}$ & $11.13 \times 10^{1}$ & $1.02 \times 10^{2}$ & $* *$ & ** & $* *$ & $* *$ \\
\hline$\geq 1 \times 10^{6}$ & $113 \times 10^{2}$ & $* *$ & $* *$ & $* *$ & $* *$ & $* *$ \\
\hline$\geq 1 \times 10^{7}$ & $* *$ & $* *$ & $* *$ & $* *$ & $* *$ & $* *$ \\
\hline
\end{tabular}

* denotes standard leakage rates of $10^{-7} \mathrm{std} \cdot \mathrm{cm}^{3} / \mathrm{s}$ or less

** denotes standard leakage rates greater than $10^{3} \mathrm{std} \cdot \mathrm{cm}^{3} / \mathrm{s}$ 



\section{Contents: Gaseous Radioactive Materials}

In this section, representative acceptance standard leakage rates for packages designed to transport gaseous radioactive materials are developed. The radioactive gases typically transported are tritium and to a lesser extent krypton-85. Additionally, there is one Type B package certified to transport a mixture of radioactive gases.

\subsection{Characteristics of Packages that Transport Gaseous Nuclear Materials}

The temperatures and pressures for normal transport conditions and for hypothetical accident conditions for the packages designed to transport gaseous radionuclides are shown in Figures 5-1a and 5.1b. There are currently three Type B packages designed for transporting tritium gas. One package was also designed to hold a mixture of gaseous radionuclides, and one package is used to transport krypton- 85 . The components in the mixture and the relative concentration of each chemical species is given in Table 5-1.

\subsection{Acceptance Leakage Rates}

For each Type B package designed to transport radioactive gas, the acceptance standard leakage rates that correspond to the normal transport conditions and the hypothetical accident conditions are calculated. The acceptance standard leakage rate for a given package and contents is calculated by determining the leak hole diameter that corresponds to the allowable release rate and then determining the standard leakage rate that corresponds to the calculated leak hole diameter. For particular radioactive gaseous contents, the acceptance standard leakage rates, which are given in Table $5-2$, are the most restrictive of the standard leakage rates calculated for the packages under normal transport conditions and for the packages under the hypothetical accident conditions.

\subsubsection{Tritium Gas}

The $\mathrm{A}_{2}$ for tritium is $1080 \mathrm{Ci}$ and the specific activity is $9.7 \times 10^{3} \mathrm{Ci} / \mathrm{g}$. For a gas, the density can be described as a function of the pressure and temperature using the ideal gas equation. For tritium, the density is:

\section{Equation 5-1}

$\rho_{\text {tritium }}=\frac{(3 \mathrm{~g} / \text { mole })}{\left(82.05 \frac{\mathrm{cm}^{3} \cdot \mathrm{atm}}{\mathrm{mole} \cdot \mathrm{K}}\right)^{\frac{\mathrm{P}}{\mathrm{T}}}}$, where:

$\mathrm{T}$ is the gas temperature $[\mathrm{K}]$, and

$\mathrm{P} \quad$ is the gas pressure [atm].

The allowable leakage rate under transport conditions is calculated by dividing the allowable release rate $(\mathrm{Ci} / \mathrm{s})$ by the product of the gas density $\left(\mathrm{g} / \mathrm{cm}^{3}\right)$ and the gas specific activity $(\mathrm{Ci} / \mathrm{g})$. For normal transport conditions, the allowable leakage rate for tritium is:

\section{Equation 5-2}

$$
\mathrm{L}_{\mathrm{N}}=\frac{10^{-6} \mathrm{~A}_{2} / \mathrm{hr}}{\rho_{\text {tritium }}\left(9.7 \times 10^{3} \mathrm{Ci} / \mathrm{g}\right)}=\left(8.46 \times 10^{-10} \frac{\mathrm{cm}^{3} \cdot \mathrm{atm}}{\mathrm{s} \cdot \mathrm{K}}\right) \frac{\mathrm{T}}{\mathrm{P}} .
$$

For hypothetical accident conditions, the allowable tritium volumetric leakage rate is:

Equation 5-3

$$
\mathrm{L}_{\mathrm{A}}=\frac{\mathrm{A}_{2} / \text { week }}{\rho_{\text {tritum }}\left(9.7 \times 10^{3} \mathrm{Ci} / \mathrm{g}\right)}=\left(5.03 \times 10^{-6} \frac{\mathrm{cm}^{3} \cdot \mathrm{atm}}{\mathrm{s} \cdot \mathrm{K}}\right) \frac{\mathrm{T}}{\mathrm{P}} .
$$

Since each package has unique normal transport conditions and hypothetical accident conditions, the allowable leakage rates are package dependent. The allowable standard leakage rate is calculated for each package and the most restrictive criterion is taken as the simplified acceptance standard leak rate. Under normal transport conditions, the acceptance standard leakage rate for containers used to transport tritium defaults to $10^{-7} \mathrm{std} \cdot \mathrm{cm}^{3} / \mathrm{s}$, the "leak tight" criterion, since the calculated acceptance standard leakage rate is less than $10^{-7} \mathrm{std} \cdot \mathrm{cm}^{3} / \mathrm{s}$. The acceptance standard leakage rate that corresponds to the hypothetical accident conditions is

$2.77 \times 10^{-5} \mathrm{std} \cdot \mathrm{cm}^{3} / \mathrm{s}$.

\subsubsection{Krypton-85 Gas}

Krypton-85 has an $A_{2}$ of $270 \mathrm{Ci}$, a specific activity of 400 $\mathrm{Ci} / \mathrm{g}$, and a molecular weight of $85 \mathrm{~g} / \mathrm{mole}$. Using the ideal gas equation, the mass density of krypton- 85 is:

\section{Equation 5-4}

$\rho_{\text {krypton }-85}=\frac{(85 \mathrm{~g} / \mathrm{mole})}{\left(82.05 \frac{\mathrm{cm}^{3} \cdot \mathrm{atm}}{\mathrm{mole} \cdot \mathrm{K}}\right)^{\mathrm{T}}}$. 
Using this equation for the density, the allowable leakage rate at normal transport conditions is:

\section{Equation 5-5}

$$
\mathrm{L}_{\mathrm{N}}=\frac{10^{-6} \mathrm{~A}_{2} / \mathrm{hr}}{\rho_{\text {krypton-85 }}(400 \mathrm{Ci} / \mathrm{g})}=\left(1.81 \times 10^{-10} \frac{\mathrm{cm}^{3} \cdot \mathrm{atm}}{\mathrm{s} \cdot \mathrm{K}}\right) \frac{\mathrm{T}}{\mathrm{P}} .
$$

At the hypothetical accident conditions, the allowable release rate of krypton-85 is $10 \mathrm{~A}_{2}$ per week. Using this release limit, the allowable leakage rate under the hypothetical accident conditions is:

\section{Equation 5-6}

$$
\mathrm{L}_{\mathrm{A}}=\frac{10 \mathrm{~A}_{2} / \text { week }}{\rho_{\text {krypton-85 }}(400 \mathrm{Ci} / \mathrm{g})}=\left(1.08 \times 10^{-5} \frac{\mathrm{cm}^{3} \cdot \mathrm{atm}}{\mathrm{s} \cdot \mathrm{K}}\right) \frac{\mathrm{T}}{\mathrm{P}} .
$$

The calculated acceptance standard leakage rate that corresponds to normal transport conditions is $10^{-7}$ $\mathrm{std} \cdot \mathrm{cm}^{3} / \mathrm{s}$, and the calculated acceptance standard leakage rate that corresponds to the hypothetical accident conditions is $7.51 \times 10^{-5} \mathrm{std} \cdot \mathrm{cm}^{3} / \mathrm{s}$.

\subsubsection{Radioactive Gas Mixtures with $\mathrm{A}_{2}=0.4 \mathrm{Ci}$}

There is one Type $B$ package that is used to transport mixtures of radionuclides. The $A_{2}$ value used for the mixture of gaseous radionuclides was $0.4 \mathrm{Ci}$, the default value. The source term activity concentration for the gas mixture was calculated as $2.846 \mathrm{Ci} / \mathrm{cm}^{3}$ from the contents that were allowed in this particular package. Under normal transport conditions, the allowable leakage rate for the gas mixture is $3.91 \times 10^{-11} \mathrm{~cm}^{3} / \mathrm{s}$, and under hypothetical accident conditions the allowable volumetric leakage rate is $2.32 \times 10^{-7} \mathrm{~cm}^{3} / \mathrm{s}$. The acceptance standard leakage rate that corresponds to normal transport conditions defaults to $10^{-7}$ $\mathrm{std} \cdot \mathrm{cm}^{3} / \mathrm{s}$, the "leak tight" criterion, since the calculated value is less than $10^{-7} \mathrm{std} \cdot \mathrm{cm}^{3} / \mathrm{s}$. The acceptance standard leak rate that corresponds to the hypothetical accident conditions is also $10^{-7} \mathrm{std} . \mathrm{cm}^{3} / \mathrm{s}$, the "leak tight" criterion.

\subsubsection{Summary of Results}

A summary of the allowable leakage rates for the three types of gaseous contents under the transport conditions is given in Table 5-1. A summary of the acceptance standard leakage rates for containers used to transport radioactive gases is given in Table 5-2. 


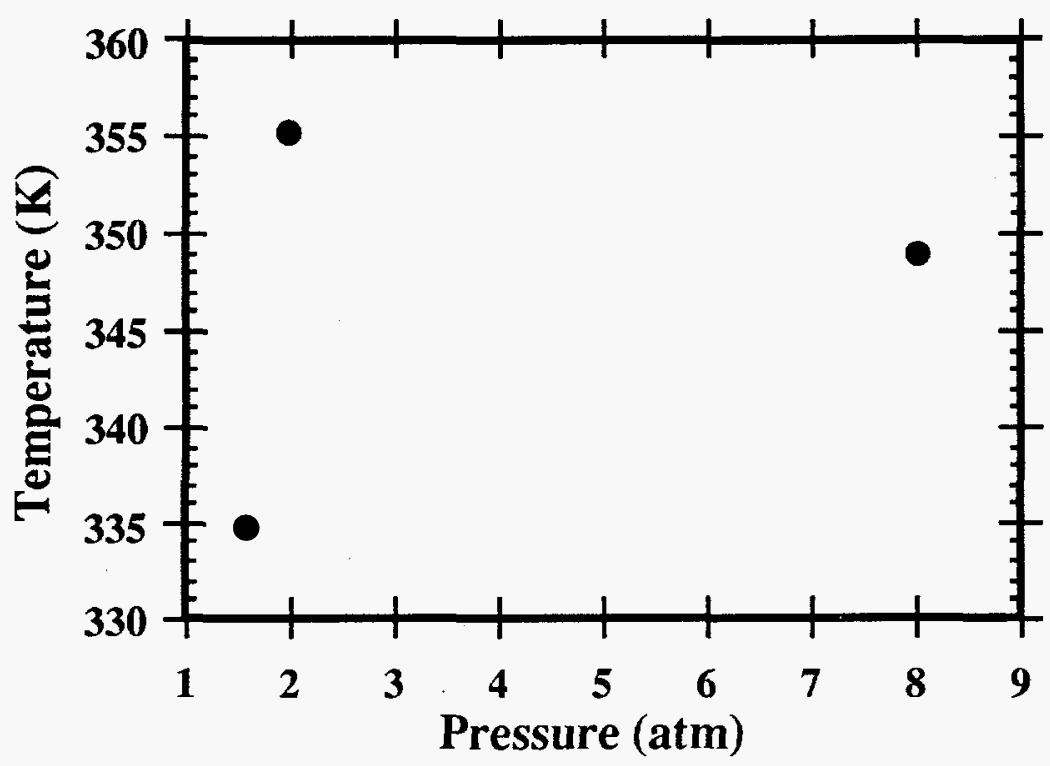

Figure 5-1a. Pressures and corresponding temperatures under normal transport conditions for packages designed to transport gaseous radionuclides.

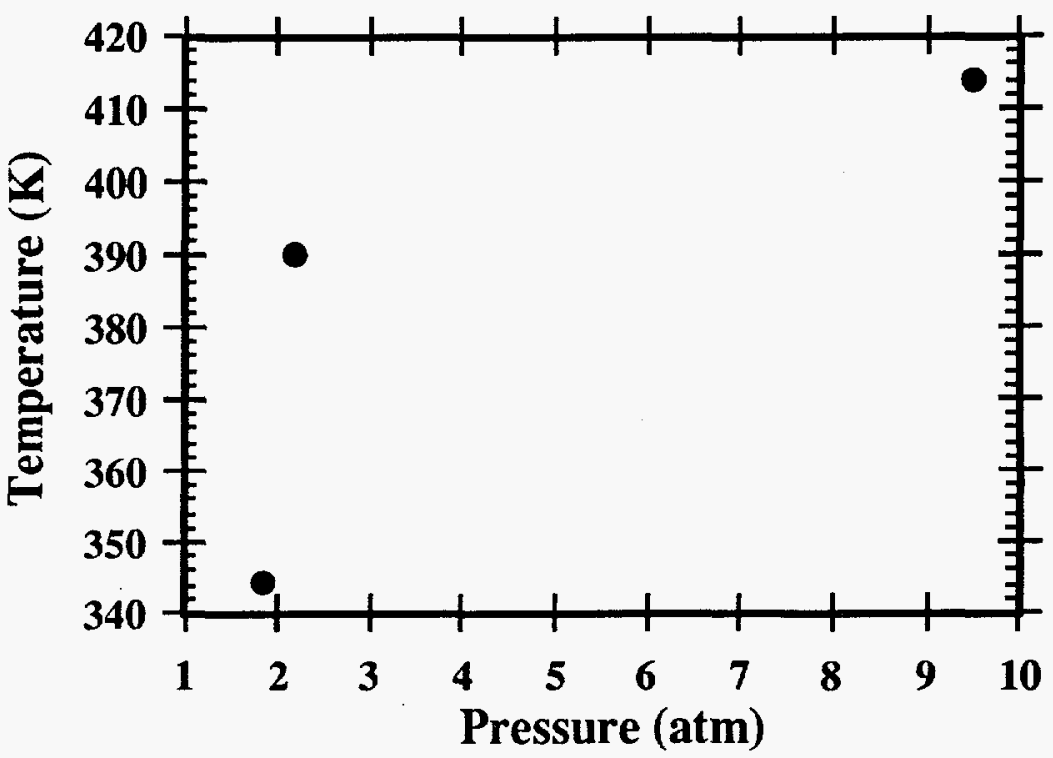

Figure 5-1b. Pressures and corresponding temperatures under hypothetical accident conditions for packages designed to transport gaseous radionuclides. 
Table 5-1. Allowable Volumetric Leakage Rates Under Normal Transport Conditions and Under Hypothetical Accident Conditions for Packages Used to Transport Gaseous Radioactive Materials

\begin{tabular}{|l|l|l|}
\hline \multirow{2}{*}{ Container Gaseous Contents } & \multicolumn{2}{|l|}{ Allowable Leakage Rates at Transport Conditions } \\
\cline { 2 - 3 } & $\begin{array}{l}\text { normal transport } \\
\text { conditions } \\
\left(\mathrm{cm}^{3} / \mathrm{s}\right)\end{array}$ & $\begin{array}{l}\text { hypothetical accident } \\
\text { conditions } \\
\left(\mathrm{cm}^{3} / \mathrm{s}\right)\end{array}$ \\
\hline Tritium & $3.69 \times 10^{-8}$ & $2.19 \times 10^{-4}$ \\
\hline Krypton-85 & $7.90 \times 10^{-9}$ & $4.71 \times 10^{-4}$ \\
\hline $\begin{array}{l}\text { Gas Mixture with } \mathrm{A}_{2}=0.4 \mathrm{Ci} \& \text { specific } \\
\text { activity of } 2.846 \mathrm{Ci} / \mathrm{cm}^{3}\end{array}$ & $3.91 \times 10^{-11}$ & $2.32 \times 10^{-7}$ \\
\hline
\end{tabular}

Table 5-2. Acceptance Standard Leakage Rates for Packages Used to Transport Radioactive Gases

\begin{tabular}{|l|l|l|}
\hline \multirow{2}{*}{ Container Gaseous Contents } & \multicolumn{2}{|l|}{ Acceptance Standard Leakage Rates } \\
\cline { 2 - 3 } & $\begin{array}{l}\text { normal transport } \\
\text { conditions }\end{array}$ & $\begin{array}{l}\text { hypothetical accident } \\
\text { conditions }\end{array}$ \\
\cline { 2 - 3 } & $\left(\mathrm{std} \cdot \mathrm{cm}^{3} / \mathrm{s}\right)$ & $\left(\mathrm{std} \cdot \mathrm{cm}^{3} / \mathrm{s}\right)$ \\
\hline \hline Tritium & leak tight $*$ & $2.40 \times 10^{-5}$ \\
\hline Krypton-85 & leak tight & $9.85 \times 10^{-5}$ \\
\hline $\begin{array}{l}\text { Gas Mixture with } \mathrm{A}_{2}=0.4 \text { Ci \& specific activity } \geq \\
2.846 \mathrm{Ci} / \mathrm{cm}^{3}\end{array}$ & leak tight & leak tight \\
\hline
\end{tabular}

* leak tight is defined as a standard leakage rate of $10^{-7} \mathrm{std} \cdot \mathrm{cm}^{3} / \mathrm{s}$ 


\section{Contents: Irradiated Fuel Assemblies}

In this section, representative acceptance standard leakage rates for packages designed to transport irradiated nuclear fuel rods are developed. The acceptance leakage rates for packages transporting BWR and PWR fuel rods are determined separately. The following contributions are considered in determining the releasable source term for packages designed to transport irradiated fuel rods: (1) the radionuclides comprising the fuel rods, (2) the radionuclides on the surface of the fuel rods, and (3) the residual contamination on the inside surfaces of the containment vessel.

\subsection{Source Terms for Spent Nuclear Fuel Assemblies}

A radioactive aerosol can be generated inside a spent fuel rod containment vessel when radioactive material from the rods or from the inside surfaces of the shipping container becomes airborne. These releasable airborne materials can originate from three sources: (1) the residual activity on the cask interior surfaces as a result of loading operations and previous shipments, (2) fission and activation-product activity associated with corrosion-deposited material (crud) on the fuel assembly surfaces, and (3) the radionuclides within the individual fuel rods comprising the fuel assemblies (Sandoval et al. 1991).

A limited group of studies indicates that the contamination due to residual activity on the cask interior surfaces is negligible as compared to crud deposits on the fuel rods. In the following analysis, this residual contamination on the interior surfaces of the cask is neglected.

The fuel has by far the largest potentially releasable radioactivity of the three sources (Sanders et al. 1992). The contribution of fuel to the overall release rate largely depends on its initial pre-transport condition and on subsequent fuel rod response to transportation loading events. Aside from vibration-induced aerosolization of radionuclide particles, the effect of transportation-related forces on the radioactive source term is not considered in this study. The loose radioactive particles that originate from spallation of crud off the fuel rod surfaces and the particles that can be emitted from breaches in the fuel rod cladding combine to form a radioactive aerosol inside the containment vessel. Clearly, the frequency of fuel rod cladding breaches would be higher for a package subject to hypothetical accident conditions as compared to the cladding breach frequency under conditions of normal transport. Vibration forces can potentially increase the density of this aerosol. Additionally, when a cladding breach occurs, radioactive gases and some volatile isotopes are released into the cask cavity and remain available for release even without vibration.
The time-dependent activity concentration of the containment vessel fill-gas can be modeled as:

\section{Equation 6-1}

$$
\frac{d C_{i}}{d t}=-\left(\frac{A_{T} D^{\prime}}{V}+\frac{A_{s} v_{s}}{V}+\frac{L_{i}}{V}\right) C_{i}+\frac{S_{i}}{V},
$$

where:

$\mathrm{C}_{\mathrm{i}}(\mathrm{t})$ is the time-dependent aerosol activity concentration $\left[\mathrm{Ci} / \mathrm{cm}^{3}\right]$, (i=N for normal, A for accident conditions),

$\mathrm{S}_{\mathrm{i}}(\mathrm{t})$ is the time-dependent activity release rate inside the containment vessel contributing to the aerosol activity $[\mathrm{Ci} / \mathrm{s}]$,

$A_{T}$ is the total surface area of cask cavity $\left[\mathrm{cm}^{2}\right]$ (including fuel and basket),

$A_{S}$ is the settling area inside cask cavity $\left[\mathrm{cm}^{2}\right]$ (including fuel and basket) (the settling area is defined as the projection of the total surface area in the upward direction),

$\mathrm{V}$ is the void volume of cask $\left[\mathrm{cm}^{3}\right]$,

$\mathrm{L}_{\mathrm{i}}$ is the volumetric gas leakage rate $\left[\mathrm{cm}^{3} / \mathrm{s}\right]\left(\mathrm{L}_{\mathrm{i}}\right.$ is assumed to be constant),

D' is the diffusive plate-out velocity of particles $[\mathrm{cm} / \mathrm{s}$, and

$v_{s}$ is the gravitational particle settling velocity $[\mathrm{cm} / \mathrm{s}]$.

The above time-dependent source-generation term in Equation $6-1, S_{i}$, is a compilation of three distinct source terms: (1) the time-dependent generation of aerosolized particles due to crud spallation, (2) the time-dependent generation of aerosolized particles due to cladding breaches, and (3) the time-dependent release of radioactive gases from cladding breaches into the containment vessel fill gas. There are also three terms that tend to reduce the aerosol mass density: (1) plate-out of particles on all the interior surfaces due to diffusion, (2) settling-out of particles due to gravity, and (3) particles entrained in gas leaking from the shipping cask.

As a conservative approach and to simplify calculations, it is assumed that crud spallation and cladding breaches occur instantaneously after fuel loading and container closure 
operations. Therefore, the source term becomes timeindependent, and all the radioactivity in the fill gas that is available for release from the containment vessel-should a leak occur-is available initially. An additional simplifying assumption, which is also conservative, is to neglect the gravitational settling and diffusive plating-out terms in Equation 6-1.

\subsubsection{Source Activity Due to Crud Spallation from Fuel Rods}

When fuel rods are subject to the radioactive and corrosive environment of a PWR or BWR reactor, radioactive flaky material is formed on the outside surface of the fuel rods. Some of this material is loosely bound to the fuel rod surface and can be dislodged in some circumstances. Vibration and flowing gases have been shown to dislodge some of the particles, forming a powder aerosol in the surrounding gas. The activity density that results inside the containment vessel as a result of crud spallation from spent fuel rods can be formulated as:

\section{Equation 6-2}

$\mathrm{C}_{\mathrm{crud}}=\frac{\mathrm{f}_{\mathrm{C}} \mathrm{M}_{\mathrm{T}}}{\mathrm{V}}=\frac{\mathrm{f}_{\mathrm{C}} \mathrm{S}_{\mathrm{C}} \mathrm{N}_{\mathrm{R}} \mathrm{N}_{\mathrm{A}} S_{\mathrm{AR}}}{\mathrm{V}}$

where:

$\mathrm{C}_{\text {crud }}$ is the activity density inside the containment vessel as a result of crud spallation $\left[\mathrm{Ci} / \mathrm{cm}^{3}\right]$,

$\mathrm{MT}_{\mathrm{T}}$ is the total crud activity inventory [Ci],

$f_{C}$ is the crud spallation fraction,

$\mathrm{V}$ is the free volume inside the containment vessel $\left[\mathrm{cm}^{3}\right.$ ],

$\mathrm{S}_{\mathrm{C}}$ is the crud surface activity $\left[\mathrm{Ci} / \mathrm{cm}^{2}\right]$,

$N_{R}$ is the number of fuel rods per assembly,

$\mathrm{N}_{\mathrm{A}}$ is the number of assemblies, and

$S_{A R}$ is the surface area per rod $\left[\mathrm{cm}^{2}\right]$.

Measurements have shown that bounding values for the crud surface activity for PWR rods ( $\mathrm{S}_{C, P W R}$ ) is $140 \times 10^{-6}$ $\mathrm{Ci} / \mathrm{cm}^{2}$, and for $\mathrm{BWR}$ rods ( $\mathrm{S}$, BWR ) is $1254 \times 10^{-6} \mathrm{Ci} / \mathrm{cm}^{2}$. Also, measurements have shown that $15 \%$ is a reasonable value for the percent of crud spallation for both PWR and $B W R$ fuel rods (i.e., $f_{C}, B W R=f_{C}, P W R=0.15$ ) under normal transportation conditions. For hypothetical accident conditions, it is assumed that there is $100 \%$ crud spallation (i.e., $\mathrm{f}_{C, B W R}=\mathrm{f}_{C, P W R}=1.0$ ). The surface area per rod is calculated based on the rod dimensions, and in this analysis the surface area associated with the assembly hardware is neglected.

\subsubsection{Source Activity due to Releases of Fines from Cladding Breaches}

A breach in the cladding of a fuel rod may allow radionuclides to be released from the resulting cladding defect into the interior of the shipping container. If there is a leak in the containment vessel, then the radioisotopes emitted from a cladding breach that were aerosolized can be entrained in the gases escaping from the shipping container and result in a radioactive release to the environment.

As a result of changing fuel rod specifications and manufacturing methods, and the large variety of mechanisms that can cause cladding breaches, estimation of the average rate of cladding breaches and the subsequent radionuclide releases is not simple. A list of observed cladding breach frequencies has been compiled by Sanders et al. and is shown in Table 6-1. The rod breach level for various breach mechanisms decreased considerable over the time period from 1969 to 1978 as a result of improvements in fuel designs and reactor operations. Although earlier fractions were much higher, since 1978 the breach fraction for PWR rods has leveled off at approximately $0.02 \%$. BWR breach levels are similar, with some years exhibiting sporadically higher values.

The estimates given below for the percent of rods that develop cladding breaches are used to predict the number of breaches that develop during transportation. As a reasonable bounding value, it is estimated that $3 \%$ of the rods develop cladding breaches during normal transportation (i.e., $\mathrm{f}_{\mathrm{B}}=0.03$ ) (Sandoval et al. 1991). This value is used for both PWR and BWR fuel rods and is 150 times greater than the experimentally determined breach frequency. Since a shipping cask under accident conditions may be dropped or crushed, which would result in large mechanical stresses on the fuel rods, for hypothetical accident conditions it is assumed that all of the rods develop a cladding breach (i.e., $\mathrm{f}_{\mathrm{B}}=1.0$ ).

There are three type of releases associated with breaches in fuel rod cladding: gaseous radionuclides, volatile radionuclides, and fuel fines (Sanders et al. 1992). Fuel fines are particulate material composed of fuel compounds and are produced as a result of the mechanical stresses at both the fuel-cladding interface and the fuel pellet-fuel pellet interface. Fines can be ejected from the fuel rod through the cladding failure by the purging action of fill and fission product gases. A sudden release of fuel fines occurs when the cladding integrity is initially lost, but no additional releases occur once equilibrium conditions are reached. Based on the limited data from three reports (see Sanders et al. 1992), roughly $0.003 \%$ of the fuel mass 
contained in a rod appears to be released as fines if the cladding on the rod ruptures (i.e., $\mathrm{f}_{\mathrm{F}}=3 \times 10^{-5}$ ) regardless of the location or temperature.

As an estimate of the typical activity of the material that constitutes a fuel rod, the data of Sanders et al. (1992) was used for rods decayed for five years, where they found that a PWR rod had an activity, AR,PWR, of $0.60 \mathrm{Ci} / \mathrm{g}$, and a $B W R$ rod had an activity of $A_{R, B W R}=0.51 \mathrm{Ci} / \mathrm{g}$. These estimates include totals from the individual radionuclides that constituted more than $0.01 \%$ of the fuel assembly's total radioactivity. The PWR rod examined was an Oconee1 Rod 08639 irradiated to $38.2 \mathrm{MWD} / \mathrm{kg} \mathrm{U}$ after 5-year decay, and the BWR rod examined was a Quad Cities-1 Fuel Rod B5A-0139 irradiated to 33.7 MWD/kg U after 5year decay.

Using the variables defined above, the activity concentration inside the containment vessel due to fines being released from cladding breaches can be formulated as:

\section{Equation 6-3}

$$
C_{\text {fines }}=\frac{f_{F} W_{R} A_{R} N_{R} N_{A} f_{B}}{V},
$$

where:

$\mathrm{C}_{\text {fines }}$ is the activity concentration inside the containment vessel as a result of fines release from cladding breaches $\left[\mathrm{Ci} / \mathrm{cm}^{3}\right]$,

$f_{F} \quad$ is the fraction of a fuel rod's mass released as fines as a result of a cladding breach $\left(\mathrm{f}_{\mathrm{F}}=3 \times 10^{-5}\right)$,

$f_{B}$ is the fraction of fuel rods that develop a cladding breach $\left(f_{\mathrm{B}, \mathrm{NTC}}=0.03, \mathrm{f}_{\mathrm{B}, \mathrm{HAC}}=1.0\right)$,

$W_{R}$ is the mass of the fuel in a fuel rod $[g]$,

Table 6-1. Fuel Rod Cladding Breach Percentages for BWR and PWR Rods Due to Normal Handling Procedures

\begin{tabular}{|l|l|l|l|}
\hline Breach Type and Location & $\begin{array}{l}\text { Fuel Rod Breach Level } \\
\text { in BWRs (\%) }\end{array}$ & $\begin{array}{l}\text { Fuel Rod Breach } \\
\text { Level in PWRs (\%) }\end{array}$ & $\begin{array}{l}\text { Period of } \\
\text { Relevance }\end{array}$ \\
\hline \hline \multicolumn{5}{|l|}{ In Reactor Breaches } & 0.50 to 0.01 & 0.35 to 0.01 & 1969 to 1977 \\
\hline Hydriding & 0.06 to 0.01 & 0.04 to 0.007 & 1964 to 1986 \\
\hline PCI & $\mathrm{a}$ & 0.03 to 0.0007 & 1983 to 1986 \\
\hline Debris-Induced Fretting & 0.05 to 0.01 & 0.01 to 0.004 & 1969 to 1986 \\
\hline Flow-Induced Fretting & $\mathrm{a}$ & 0.0024 & 1973 to 1986 \\
\hline Baffle Jetting & 0.002 & 0.002 & 1973 to 1976 \\
\hline Cladding Corrosion & 0.02 to 0.07 & $\mathrm{a}$ & 1981 to 1983 \\
\hline CILC & 0.002 & 0.002 & 1973 to 1978 \\
\hline Corrosion by CRUD & 0.05 & 0.007 & 1979 \\
\hline Out-of-Reactor Breaches & & & b \\
\hline Fuel Handling & 0.0003 & $\mathrm{~b}$ & $\mathrm{~b}$ \\
\hline Wet Storage & $\mathrm{c}$ & $\mathrm{c}$ & $\mathrm{b}$ \\
\hline Consolidation & $\mathrm{c}$ & $<0.005$ & $\mathrm{~b}$ \\
\hline Dry Storage & $\mathrm{c}$ & 0.03 & \\
\hline
\end{tabular}

"a" denotes not applicable

" $b$ " denotes no data available

"c" denotes no breaches as of Dec. 31,1986 
$N_{R}$ is the number of fuel rods per assembly,

NA is the number of assemblies,

$A_{R} \quad$ is the specific activity of the fines emitted from a cladding breach in a fuel rod $[\mathrm{Ci} / \mathrm{g}]\left(\mathrm{A}_{\mathrm{R}, \mathrm{PWR}}=0.60\right.$ $\mathrm{Ci} / \mathrm{g}, \mathrm{AR}_{\mathrm{R}, \mathrm{BWR}}=0.51 \mathrm{Ci} / \mathrm{g}$ ), and

$\mathrm{V}$ is the containment vessel void volume $\left[\mathrm{cm}^{3}\right]$.

\subsubsection{Source Activity from Gases and Volatiles Released due to Cladding Breaches}

If a cladding failure occurs in a fuel rod, a large fraction of the gap inventories of the fill and fission product gases (tritium, iodine, krypton and xenon) will be introduced into the free volume of the transport cask. Tritium and krypton85 are typically the major sources of radioactivity among the gases present. Volatile species, such as cesium, strontium, and ruthenium, can also be released from a fuel rod as a result of a cladding breach. Although some of these isotopes may only be volatile under the hypothetical accident conditions, they are included in the analysis for normal transport conditions as a conservative approach. The concentration due to these releases can be represented by:

\section{Equation 6-4}

$C_{\text {vol\&gas }}=C_{v o l}+C_{g a s}=\frac{N_{R} N_{A} f_{B} W_{R}\left(A_{V} f_{V}+A_{G} f_{G}\right)}{V}$,

here:

$\mathrm{C}_{\mathrm{vol} \& \text { gas }}$ is the releasable activity concentration inside the containment vessel due to gases and volatiles that are released from cladding breaches $\left[\mathrm{Ci} / \mathrm{cm}^{3}\right]$,

$\mathrm{C}_{\mathrm{vol}}$ is the releasable activity concentration inside the containment vessel due to volatiles released from cladding breaches $\left[\mathrm{Ci} / \mathrm{cm}^{3}\right]$,

$\mathrm{C}_{\text {gas }}$ is the releasable activity concentration inside the containment vessel due to gases released from cladding breaches $\left[\mathrm{Ci} / \mathrm{cm}^{3}\right]$,

$W_{R} \quad$ is the mass of the fuel in a fuel rod $[\mathrm{g}]$,

$\mathrm{N}_{\mathrm{R}}$ is the total number of rods per assembly,

$\mathrm{N}_{\mathrm{A}} \quad$ is the number of assemblies,

$\mathrm{f}_{\mathrm{B}}$ is the fraction of rods that develop cladding breaches,
Av is the specific activity of the volatiles in a fuel $\operatorname{rod}[\mathrm{Ci} / \mathrm{g}]$,

$\mathrm{fV}_{\mathrm{V}} \quad$ is the fraction of volatiles in a fuel rod released if the rod develops a cladding breach,

A ${ }_{G}$ is the specific activity of the gas in a fuel rod [Ci/g],

$f_{G} \quad$ is the fraction of gas that would escape from a fuel rod that developed a cladding breach, and

$\mathrm{V}$ is the void volume inside the containment vessel $\left[\mathrm{cm}^{3}\right]$.

Based on limited experimental data, it is conservatively estimated that $30 \%$ of the fission product gases escape from a fuel rod as the result of a cladding breach (i.e., $\mathrm{f}_{\mathrm{G}}=0.3$ ).

Limited experimental data also suggest that $2 \times 10^{-4}$ is a conservative bounding value for the fraction of the volatiles released from a fuel rod (i.e., $\mathrm{fV}=2 \times 10^{-4}$ ) as a result of a cladding breach.

Using the computer code Origen2 (version 2.1), the radioisotope inventory was calculated for 1 metric ton of uranium fuel enriched to $3.2 \%$ with a burnup of 33,000 MWD/MTIHM. For PWR fuel that was cooled for 5 years, the specific activity of the gases was $7.32 \mathrm{Ci} / \mathrm{kg}$ fuel (i.e., $\mathrm{A}_{\mathrm{G}, P W R}=7.32 \mathrm{Ci} / \mathrm{kg}=7.32 \times 10^{-3} \mathrm{Ci} / \mathrm{g}$ ), and the specific activity of the volatile isotopes was $137.5 \mathrm{Ci} / \mathrm{kg}$ fuel (i.e., AV,PWR $=137.5 \mathrm{Ci} / \mathrm{kg}=0.1375 \mathrm{Ci} / \mathrm{g}$ ). For BWR fuel cooled for 5 years, the specific activity of the gases was $6.28 \mathrm{Ci} / \mathrm{kg}$ fuel (i.e., $A_{G, B W R}=6.28 \mathrm{Ci} / \mathrm{kg}=6.28 \times 10^{-3} \mathrm{Ci} / \mathrm{g}$ ), and the specific activity of the volatiles was $179.4 \mathrm{Ci} / \mathrm{kg}$ fuel (i.e., $\left.A_{V, B W R}=179.4 \mathrm{Ci} / \mathrm{kg}=0.1794 \mathrm{Ci} / \mathrm{g}\right)$.

\subsubsection{Total Source Term for Packages that Contain Irradiated Fuel Rods}

Combining Equations 6-2, 6-3, and 6-4 gives the equation for the total source term activity concentration:

\section{Equation 6-5}

$\mathrm{C}_{\text {total }}=\mathrm{C}_{\mathrm{crud}}+\mathrm{C}_{\mathrm{fines}}+\mathrm{C}_{\mathrm{vol}}+\mathrm{C}_{\mathrm{gas}}$,

where $C_{\text {total }}$ has units of $\mathrm{Ci} / \mathrm{cm}^{3}$. Substituting for the individual source term contributions in Equation 6-5 gives: 


\section{Equation 6-6}

$$
\begin{aligned}
C_{\text {total }}= & \frac{f_{C} S_{C} N_{R} N_{A} S_{A R}}{V}+\frac{f_{F} W_{R} A_{R} N_{R} N_{A} f_{B}}{V}+ \\
& \frac{N_{R} N_{A} f_{B} W_{R}\left(A_{V} f_{V}+A_{G} f_{G}\right)}{V} .
\end{aligned}
$$

Table 6-2 provides a summary of the values for the various terms used to calculate the allowable leakage rate for containers designed to transport irradiated fuel rods.

Tables 6-3a, 6-3b, 6-4a, and 6-4b give characteristics of $P W R$ and BWR fuel assemblies and various PWR and BWR fuel types. From these tables, characteristic values of the rod surface area per assembly and the total rod weight per assembly can be determined. Although typical values are used to describe the total rod mass in an assembly for calculational purposes, the bounding assessments used for fuel-rod-breach frequency and other release fraction terms ensure that the calculated source term activity concentrations have a net conservatism.

The characteristic values used for PWR rod assemblies are a rod surface area per assembly of $3 \times 10^{5} \mathrm{~cm}^{2}\left(\mathrm{~N}_{\mathrm{R}} \mathrm{S}_{\mathrm{AR}}\right)$ and a fuel mass per assembly of $5.2 \times 10^{5} \mathrm{~g}\left(\mathrm{~N}_{R} W_{R}\right)$. The characteristic values used for BWR rod assemblies are rod surface area per assembly of $10^{5} \mathrm{~cm}^{2}\left(\mathrm{~N}_{\mathrm{R}} \mathrm{S}_{\mathrm{AR}}\right)$ and the fuel mass per assembly of $2.2 \times 10^{5} \mathrm{~g}\left(\mathrm{~N}_{\mathrm{R}} \mathrm{W}_{\mathrm{R}}\right)$. In choosing these characteristic values, some of the fuel types not expected to be transported (which were typically the lower surfacearea-per-assembly and fuel-mass-per-assembly values) were not considered in the evaluation. The characteristic value for the fuel assembly surface area includes the surface area associated with fuel rods and spacer rods.

\begin{tabular}{|c|c|c|c|c|}
\hline \multirow[b]{2}{*}{ Variable } & \multicolumn{2}{|l|}{ PWR } & \multicolumn{2}{|l|}{ BWR } \\
\hline & $\begin{array}{l}\text { normal } \\
\text { transport } \\
\text { conditions }\end{array}$ & $\begin{array}{l}\text { hypothetical } \\
\text { accident } \\
\text { conditions }\end{array}$ & $\begin{array}{l}\text { normal } \\
\text { transport } \\
\text { conditions }\end{array}$ & $\begin{array}{l}\text { hypothetical } \\
\text { accident } \\
\text { conditions }\end{array}$ \\
\hline Fraction of crud that spalls-off of rods, $\mathrm{f} C$ & 0.15 & 1.0 & 0.15 & 1.0 \\
\hline crud surface activity, $\mathrm{S}_{\mathrm{C}}\left[\mathrm{Ci} / \mathrm{cm}^{2}\right]$ & $140 \times 10^{-6}$ & $140 \times 10^{-6}$ & $1254 \times 10^{-6}$ & $1254 \times 10^{-6}$ \\
\hline $\begin{array}{l}\text { Mass fraction of fuel that is released as fines } \\
\text { due to a cladding breach, } \mathrm{f}_{\mathrm{F}}\end{array}$ & $3 \times 10^{-5}$ & $3 \times 10^{-5}$ & $3 \times 10^{-5}$ & $3 \times 10^{-5}$ \\
\hline Specific activity of fuel rods, $A_{R}[\mathrm{Ci} / g]$ & 0.60 & 0.60 & 0.51 & 0.51 \\
\hline $\begin{array}{l}\text { Fraction of rods that develop cladding } \\
\text { breaches, } \mathrm{f}_{\mathrm{B}}\end{array}$ & 0.03 & 1.0 & 0.03 & 1.0 \\
\hline $\begin{array}{l}\text { Fraction of gases that are released due to a } \\
\text { cladding breach, } \mathrm{f}_{\mathrm{G}}\end{array}$ & 0.3 & 0.3 & 0.3 & 0.3 \\
\hline $\begin{array}{l}\text { Specific activity of gases in a fuel rod, } A_{G} \\
{[\mathrm{Ci} / \mathrm{g}]}\end{array}$ & $7.32 \times 10^{-3}$ & $7.32 \times 10^{-3}$ & $6.28 \times 10^{-3}$ & $6.28 \times 10^{-3}$ \\
\hline $\begin{array}{l}\text { Specific activity of volatiles in a fuel rod, AV } \\
{[\mathrm{Ci} / \mathrm{g}]}\end{array}$ & 0.1375 & 0.1375 & 0.1794 & 0.1794 \\
\hline $\begin{array}{l}\text { Fraction of volatiles that are released due to a } \\
\text { cladding breach, } f_{V}\end{array}$ & $2 \times 10^{-4}$ & $2 \times 10^{-4}$ & $2 \times 10^{-4}$ & $2 \times 10^{-4}$ \\
\hline
\end{tabular}

Table 6-2. Variables Used to Predict the Source Term for Packages Designed to Transport Irradiated Fuel Rods 
6. Irradiated Fuel Assemblies

Table 6-3a. Selected Physical Characteristics of PWR Fuel Rods [SA1]

\begin{tabular}{|c|c|c|c|c|c|}
\hline \multicolumn{2}{|c|}{ PWR Fuel Rods } & \multirow[b]{2}{*}{ Version } & \multirow[b]{2}{*}{$\begin{array}{l}\text { Number of } \\
\text { rods per } \\
\text { assembly }\end{array}$} & \multirow[b]{2}{*}{ Rod Mass (kg) } & \multirow[b]{2}{*}{$\begin{array}{l}\text { Total rod mass } \\
\text { per assembly } \\
\text { (kg) }\end{array}$} \\
\hline Mnfr. & Array & & & & \\
\hline B\&W & $14 \times 14$ & & & & \\
\hline B\&W & $15 \times 15$ & Mark B & 203 & 3.17 & 643.51 \\
\hline$B \& W$ & $15 \times 15$ & St. Steel & 204 & 2.68 & 546.72 \\
\hline B\&W & $17 \times 17$ & Mark C & 264 & 2.22 & 586.08 \\
\hline B\&W & $15 \times 15$ & Mark BZ & 208 & 3.18 & 661.44 \\
\hline CE & $14 \times 14$ & Standard & 164 & 3.13 & 513.32 \\
\hline CE & $14 \times 14$ & Fort Calhoun & 168 & 2.95 & 495.60 \\
\hline $\mathrm{CE}$ & $15 \times 15$ & Palisades & 204 & 2.63 & 536.52 \\
\hline $\mathrm{CE}$ & $16 \times 16$ & Onofre & 224 & 2.59 & 580.16 \\
\hline$C E$ & $16 \times 16$ & St. Lucie/2 & 224 & 2.36 & 528.64 \\
\hline $\mathrm{CE}$ & $16 \times 16$ & ANO $/ 2$ & 232 & 2.59 & 600.88 \\
\hline $\mathrm{CE}$ & $16 \times 16$ & System 80 & 220 & 2.59 & 569.80 \\
\hline ANF & $14 \times 14$ & WE & 179 & 3.03 & 542.37 \\
\hline ANF & $14 \times 14$ & $\mathrm{CE}$ & 176 & 3.13 & 550.88 \\
\hline ANF & $14 \times 14$ & Top Rod & 179 & 2.94 & 526.26 \\
\hline ANF & $15 \times 15$ & WE & 204 & 3.05 & 622.20 \\
\hline ANF & $15 \times 15$ & $C E$ & 216 & 2.67 & 576.72 \\
\hline ANF & $17 \times 17$ & WE & 264 & 2.21 & 583.44 \\
\hline WE & $14 \times 14$ & Std/ZCA & 179 & 3.03 & 542.37 \\
\hline WE & $14 \times 14$ & OFA & 179 & 2.78 & 497.62 \\
\hline WE & $14 \times 14$ & Std/ZCB & 179 & 3.03 & 542.37 \\
\hline WE & $14 \times 14$ & $\mathrm{Std} / \mathrm{SC}$ & 180 & 2.98 & 536.40 \\
\hline WE & $14 \times 14$ & Model C & 176 & 3.11 & 547.36 \\
\hline WE & $15 \times 15$ & Std/ZC & 204 & 3.11 & 634.44 \\
\hline WE & $15 \times 15$ & OFA & 204 & 3.08 & 628.32 \\
\hline WE & $15 \times 15$ & $\mathrm{Std} / \mathrm{ZC}$ & 204 & 2.98 & 607.92 \\
\hline WE & $17 \times 17$ & Standard & 264 & 2.44 & 644.16 \\
\hline WE & $17 \times 17$ & OFA & 264 & 2.24 & 591.36 \\
\hline WE & $17 \times 17$ & Vantage 5 & 264 & 1.82 & 480.48 \\
\hline WE & $17 \times 17$ & XLR & & & \\
\hline WE & $13 \times 13$ & & & & \\
\hline
\end{tabular}

blank entries indicate no data available 
Table 6-3b. Selected Physical Characteristics of BWR Fuel Rods [SA1]

\begin{tabular}{|c|c|c|c|c|c|}
\hline \multicolumn{6}{|c|}{ BWR Fuel Rods } \\
\hline Mnfr. & Array & Version & $\begin{array}{l}\text { Typ. Number } \\
\text { of Rods }\end{array}$ & $\begin{array}{l}\text { Rod Mass } \\
\text { (kg) }\end{array}$ & $\begin{array}{l}\text { Total Rod } \\
\text { Mass (kg) }\end{array}$ \\
\hline ANF & $6 \times 6$ & GE & 35 & 4.0188 & 140.658 \\
\hline ANF & $7 \times 7$ & GE & 48 & 5.629 & 270.192 \\
\hline ANF & $8 \times 8$ & JP-3 & 63 & 4.0596 & 255.7548 \\
\hline ANF & $8 \times 8$ & JP-4,-5 & 62 & 4.1503 & 257.3186 \\
\hline ANF & $9 \times 9$ & JP-3 & 79 & 3.0798 & 243.3042 \\
\hline ANF & $9 \times 9$ & $J P-4,-5$ & 79 & 3.1796 & 251.1884 \\
\hline ANF & $10 \times 10$ & $\mathrm{AC}$ & 96 & 1.6011 & 153.7056 \\
\hline ANF & $11 \times 11$ & $\mathrm{GE}$ & 117 & 1.6782 & 196.3494 \\
\hline ANF & $9 \times 9$ & BRP & & & \\
\hline ANF & $6 \times 6$ & Humbolt Bay & 36 & & \\
\hline WE & $8 \times 8$ & QUAD+ & 64 & & \\
\hline GE & $6 \times 6$ & Dresden-1 & 36 & & \\
\hline GE & $6 \times 6$ & Humbolt Bay & 36 & & \\
\hline $\mathrm{GE}$ & $7 \times 7$ & & 49 & & \\
\hline GE & $7 \times 7$ & & 49 & & \\
\hline GE & $7 \times 7$ & & 49 & & \\
\hline $\mathrm{GE}$ & $7 \times 7$ & & 49 & . & \\
\hline GE & $8 \times 8$ & & & & \\
\hline $\mathrm{GE}$ & $8 \times 8$ & & 63 & & \\
\hline GE & $8 \times 8$ & & 62 & & \\
\hline GE & $9 \times 9$ & & 81 & & \\
\hline GE & $11 \times 11$ & & 111 & & \\
\hline
\end{tabular}

blank entries indicate no data available 
Table 6-4a. Dimensions of PWR Fuel [DOE/RW-0184-R1]

\begin{tabular}{|c|c|c|c|c|c|c|c|c|c|c|c|}
\hline Class & \begin{tabular}{|l|} 
Array \\
Size
\end{tabular} & $\begin{array}{l}\text { Rod } \\
\text { length } \\
\text { (in) }\end{array}$ & $\begin{array}{l}\text { Rod } \\
\text { diam. } \\
\text { (in) }\end{array}$ & $\begin{array}{l}\text { Surface } \\
\text { area } \\
\text { per rod } \\
\left(\mathrm{cm}^{2}\right)\end{array}$ & $\begin{array}{l}\text { No. of } \\
\text { rods } \\
\text { per } \\
\text { assem. }\end{array}$ & $\begin{array}{l}\text { Surface } \\
\text { area per } \\
\text { assembly } \\
\left(\mathrm{cm}^{2}\right)\end{array}$ & $\begin{array}{l}\text { Active } \\
\text { fuel } \\
\text { length } \\
\text { (in) }\end{array}$ & $\begin{array}{l}\text { Pellet } \\
\text { diam. } \\
\text { (in) }\end{array}$ & $\begin{array}{l}\text { Vol. of } \\
\text { fuel in } \\
\text { a rod } \\
\left(\mathrm{cm}^{3}\right)\end{array}$ & $\begin{array}{l}\text { Mass } \\
\text { of fuel } \\
\text { in a } \\
\operatorname{rod}(g)\end{array}$ & $\begin{array}{l}\text { Mass of } \\
\text { fuel in an } \\
\text { assembly } \\
\text { (g) }\end{array}$ \\
\hline$B \& W$ & $15 \times 15$ & 153.68 & 0.43 & 1339.4 & 208 & $3.014 \times 10^{5}$ & 141.8 & 0.3686 & 248.0 & 2717.6 & $5.65 \times 10^{5}$ \\
\hline$B \& W$ & $17 \times 17$ & 152.68 & 0.379 & 1172.9 & 264 & $3.390 \times 10^{5}$ & 143 & 0.3232 & 192.3 & 2107.1 & $5.56 \times 10^{5}$ \\
\hline CE & $14 \times 14$ & 147 & 0.44 & 1311.0 & 164 & $2.569 \times 10^{5}$ & 137 & 0.3765 & 249.9 & 2739.4 & $4.49 \times 10^{5}$ \\
\hline $\mathrm{CE}$ & $14 \times 14$ & 146.44 & 0.44 & 1306.0 & 176 & $2.560 \times 10^{5}$ & 136.7 & 0.3805 & 254.7 & 2791.8 & $4.91 \times 10^{5}$ \\
\hline CE & $16 \times 16$ & 161 & 0.382 & 1246.5 & 224 & $3.191 \times 10^{5}$ & 150 & 0.325 & 203.9 & 2234.9 & $5.01 \times 10^{5}$ \\
\hline WE & $14 \times 14$ & 152.4 & 0.422 & 1303.5 & 179 & $2.555 \times 10^{5}$ & 145.2 & 0.3674 & 252.3 & 2764.7 & $4.95 \times 10^{5}$ \\
\hline WE & $15 \times 15$ & 151.85 & 0.422 & 1298.8 & 204 & $2.922 \times 10^{5}$ & 144 & 0.3659 & 248.1 & 2719.5 & $5.55 \times 10^{5}$ \\
\hline WE & $17 \times 17$ & 152.3 & 0.36 & 1111.3 & 264 & $3.212 \times 10^{5}$ & 144 & 0.3088 & 176.7 & 1936.9 & $5.11 \times 10^{5}$ \\
\hline $\begin{array}{l}\text { Ft.. } \\
\text { Calhoun }\end{array}$ & $14 \times 14$ & 137 & 0.44 & 1221.8 & 168 & $2.395 \times 10^{5}$ & 128 & 0.3765 & 233.5 & 2559.4 & $4.30 \times 10^{5}$ \\
\hline $\begin{array}{l}\text { Haddam } \\
\text { Neck }\end{array}$ & $15 \times 15$ & 126.72 & 0.422 & 1083.9 & 204 & $2.439 \times 10^{5}$ & 122 & 0.3895 & 238.2 & 2610.8 & $5.33 \times 10^{5}$ \\
\hline Palisades & $15 \times 15$ & 140 & 0.418 & 1186.1 & 204 & $2.669 \times 10^{5}$ & 132 & 0.358 & 217.7 & 2386.4 & $4.87 \times 10^{5}$ \\
\hline Palisades & $15 \times 15$ & 139.42 & 0.417 & 1178.4 & 216 & $2.651 \times 10^{5}$ & 131.8 & 0.358 & 217.4 & 2382.8 & $5.15 \times 10^{5}$ \\
\hline St. Lucie & $16 \times 16$ & 146.49 & 0.382 & 1134.3 & 224 & $2.904 \times 10^{5}$ & 136.7 & 0.325 & 185.8 & 2036.7 & $4.56 \times 10^{5}$ \\
\hline $\begin{array}{l}\text { San } \\
\text { Onofre 1 }\end{array}$ & $14 \times 14$ & 126.68 & 0.422 & 1083.5 & 180 & $2.124 \times 10^{5}$ & 120 & 0.3835 & 227.1 & 2489.5 & $4.48 \times 10^{5}$ \\
\hline $\begin{array}{l}\text { Yankee } \\
\text { Rowe }\end{array}$ & $15 \times 16$ & 95.34 & 0.365 & 705.3 & 236 & $1.693 \times 10^{5}$ & 91 & 0.3105 & 112.9 & 1237.6 & $2.92 \times 10^{5}$ \\
\hline
\end{tabular}


Table 6-4b. Dimensions of BWR Fuel [DOE/RW-0184-R1]

\begin{tabular}{|c|c|c|c|c|c|c|c|c|c|c|c|}
\hline Class & $\begin{array}{l}\text { Array } \\
\text { Size }\end{array}$ & $\begin{array}{l}\text { Rod } \\
\text { length } \\
\text { (in) }\end{array}$ & $\begin{array}{l}\text { Rod } \\
\text { diam } \\
\text { (in) }\end{array}$ & $\begin{array}{l}\text { Surface } \\
\text { area } \\
\text { per rod } \\
\left(\mathrm{cm}^{2}\right)\end{array}$ & $\begin{array}{l}\text { No. of } \\
\text { rods } \\
\text { per } \\
\text { assem. }\end{array}$ & $\begin{array}{l}\text { Surface } \\
\text { area per } \\
\text { assembly } \\
\left(\mathrm{cm}^{2}\right)\end{array}$ & $\begin{array}{l}\text { Active } \\
\text { fuel } \\
\text { length } \\
\text { (in) }\end{array}$ & $\begin{array}{l}\text { Pellet } \\
\text { diam. } \\
\text { (in) }\end{array}$ & $\begin{array}{l}\text { Vol. of } \\
\text { fuel in } \\
\text { a rod } \\
\left(\mathrm{cm}^{3}\right)\end{array}$ & $\begin{array}{l}\text { Mass } \\
\text { of fuel } \\
\text { in a } \\
\operatorname{rod}(\mathrm{g})\end{array}$ & $\begin{array}{l}\text { Mass of } \\
\text { fuel } \\
\text { in an } \\
\text { assembly } \\
\text { (g) }\end{array}$ \\
\hline GE 2-3 & $7 \times 7$ & 158.15 & 0.57 & 1827.1 & 48 & $8.935 \times 10^{4}$ & 144 & 0.49 & 445.0 & 4877.0 & $2.34 \times 10^{5}$ \\
\hline GE 2-3 & $8 \times 8$ & 158 & 0.483 & 1546.8 & 62 & $9.899 \times 10^{4}$ & 145.24 & 0.41 & 314.2 & 3443.9 & $2.14 \times 10^{5}$ \\
\hline GE 2-3 & $8 \times 8$ & 158.66 & 0.484 & 1556.5 & 63 & $9.961 \times 10^{4}$ & 145.24 & 0.4195 & 329.0 & 3605.4 & $2.27 \times 10^{5}$ \\
\hline GE 2-3 & $9 \times 9$ & 159.07 & 0.424 & 1367.0 & 79 & $1.107 \times 10^{5}$ & 145.24 & 0.3565 & 237.6 & 2603.8 & $2.06 \times 10^{5}$ \\
\hline GE 4-6 & $7 \times 7$ & 158 & 0.563 & 1802.9 & 49 & $8.834 \times 10^{4}$ & 144 & 0.487 & 439.6 & 4817.5 & $2.36 \times 10^{5}$ \\
\hline GE 4-6 & $8 \times 8$ & 158 & 0.493 & 1578.8 & 63 & $1.010 \times 10^{5}$ & 144 & 0.416 & 320.7 & 3515.2 & $2.21 \times 10^{5}$ \\
\hline GE 4-6 & $8 \times 8$ & 163.42 & 0.484 & 1603.2 & 62 & $1.026 \times 10^{5}$ & 150 & 0.3913 & 295.6 & 3239.8 & $2.01 \times 10^{5}$ \\
\hline $\begin{array}{l}\text { Humbolt } \\
\text { Bay }\end{array}$ & $7 X 7$ & 83.2 & 0.486 & 819.6 & 49 & $4.016 \times 10^{4}$ & 79 & 0.411 & 171.8 & 1882.4 & $9.22 \times 10^{4}$ \\
\hline
\end{tabular}


Substituting the appropriate terms into Equation 6-6, the source term activity concentration is obtained in terms of the number of fuel assemblies in a transportation package and the void volume of the containment vessel. For PWR fuel under normal transport conditions, the source term activity concentration is:

\section{Equation 6-7}

$C_{\text {total }, \text { PWR,NTC }}=\frac{N_{A}}{V}(41.27 \mathrm{Ci} /$ assembly $)$,

where $\mathbf{N}_{A}$ is the number of fuel assemblies in the containment vessel, and $\mathrm{V}$ is the void volume of the containment vessel $\left[\mathrm{cm}^{3}\right]$ when filled with fuel. For PWR fuel under hypothetical accident conditions, the source term activity concentration is:

\section{Equation 6-8}

$C_{\text {total,PWR,HAC }}=\frac{N_{A}}{V}(1207.6 \mathrm{Ci} /$ assembly $)$.

For BWR fuel under normal transport conditions, the source term activity concentration is:

\section{Equation 6-9}

$C_{\text {total, BWR, NTC }}=\frac{N_{A}}{V}(31.58 \mathrm{Ci} /$ assembly $)$.
For BWR fuel at hypothetical accident conditions, the source term activity concentration is:

\section{Equation 6-10}

$\mathrm{C}_{\text {total,BWR,HAC }}=\frac{N_{A}}{V}(551.14 \mathrm{Ci} /$ assembly $)$,

The contributions from the individual sources (i.e., crud, fines, volatiles, and gases) that contribute to the source term activity for PWR and BWR fuel under normal transport conditions and hypothetical accident conditions are summarized in Table 6-5. From this table it is clear that for PWR fuel under normal transport conditions, the major contributor to the source term activity is the release of gas from cladding breaches. The released gases are also the major contributor to the source term activity for PWR fuel under hypothetical accident conditions. However, for BWR fuel under normal transport conditions, the contributions to the source term activity from crud and gases is comparable to the contribution from the crud being slightly higher. When BWR fuel is subject to hypothetical accident conditions, the major contributor to the source term activity is the release of gas from cladding breaches. The majority of the activity associated with crud is due to cobalt- 60 , and the majority of the activity associated with the gases is due to krypton-85.

Table 6-5 Contributions to Source Term for Packages Designed to Transport Irradiated Fuel Rods.

\begin{tabular}{|c|c|c|c|c|c|c|}
\hline \multirow[b]{2}{*}{$\begin{array}{l}\text { Fuel } \\
\text { Type }\end{array}$} & \multirow[b]{2}{*}{$\begin{array}{l}\text { Transport } \\
\text { Conditions }\end{array}$} & \multicolumn{4}{|c|}{ Individual Contributions to Source Term } & \multirow[b]{2}{*}{$\begin{array}{l}\text { Total } \\
\text { Contribution } \\
\text { (Ci/assembly) }\end{array}$} \\
\hline & & $\begin{array}{l}\text { Contribution } \\
\text { from Crud } \\
\text { (Ci/assembly) }\end{array}$ & $\begin{array}{l}\text { Contribution from } \\
\text { Fuel Fines } \\
\text { (Ci/assembly) }\end{array}$ & $\begin{array}{l}\text { Contribution } \\
\text { from Volatiles } \\
\text { (Ci/assembly) }\end{array}$ & $\begin{array}{l}\text { Contribution } \\
\text { from Gases } \\
\text { (Ci/assembly) }\end{array}$ & \\
\hline PWR & $\mathrm{NTC}^{*}$ & 5.46 & 0.28 & 0.43 & 34.26 & 41.27 \\
\hline PWR & HAC** & 36.40 & 9.36 & 14.30 & 1141.9 & 1207.6 \\
\hline BWR & NTC & 18.81 & 0.101 & 0.237 & 12.43 & 31.58 \\
\hline BWR & HAC & 125.40 & 3.37 & 7.89 & 414.48 & 551.1 \\
\hline
\end{tabular}

* NTC denotes normal transport conditions

** HAC denotes hypothetical accident conditions 


\subsection{Acceptance Criteria for Leakage Tests}

Before the allowable leakage rate under transport conditions and the corresponding standard leakage rates can be calculated, the allowable radionuclide release rates need to be determined for both normal transport and hypothetical accident conditions. Determining the allowable release rate requires knowledge of the effective $A_{2}$ of the releasable contents, which depends on the fuel type and the transport conditions.

To calculate the effective $A_{2}$ of the releasable contents in a transportation container used to transport irradiated fuel rods, the $A_{2}$ of the individual contributions are needed (i.e., the $A_{2}$ of the crud, the fuel fines, the gases, and the volatiles). The $A_{2}$ value used for the crud is dominated by the cobalt- 60 in the crud. The effect of the cobalt- 60 on the $A_{2}$ of the crud is so strong that the $A_{2}$ value used for the crud, for both PWR and BWR fuel rods, is the same as that of cobalt- 60 , which is $10.8 \mathrm{Ci}(0.4 \mathrm{TBq})$. The fines emitted from a cladding breach are composed of the solid fuel material that is neither gaseous nor volatile. The calculated $\mathrm{A}_{2}$ for the fines was $0.264 \mathrm{Ci}\left(9.8 \times 10^{-3} \mathrm{TBq}\right)$, which is used for fines from both PWR and BWR fuel rods. The $A_{2}$ for the gases and volatiles are different for PWR and BWR fuel rods, so these four terms must be calculated independently.

Using the results of Origen2 (version 2.1) to determine the isotopes present in 5-year-old irradiated fuel that was initially enriched to $3.2 \%$ and had a burnup of 33 $\mathrm{kWD} / \mathrm{KgU}$, the effective $A_{2}$ for the gases and volatiles present were calculated for PWR and BWR fuel rods. For PWR fuel rods, the $\mathrm{A}_{2}$ for the gases was dominated by the krypton-85, and to a lesser extent the tritium which resulted in an effective $A_{2}$ for the gases of $418.6 \mathrm{Ci}(15.5 \mathrm{TBq})$. For PWR fuel rods, the $A_{2}$ for the volatiles was dominated by the ruthenium-106 and cesium-137, which resulted in an $A_{2}$ for the volatiles of $11.38 \mathrm{Ci}(0.42 \mathrm{TBq})$. For $\mathrm{BWR}$ fuel rods, the $A_{2}$ for the gases was dominated by the krypton85 , which resulted in an $A_{2}$ for the gases of $282.5 \mathrm{Ci}$ (10.46 TBq). For BWR fuel rods, the $A_{2}$ for the volatiles was dominated by the strontium- 90 and to a lesser extent by cesium-137, ruthenium-106, and cesium-134, which resulted in an $\mathrm{A}_{2}$ for the volatiles of $5.62 \mathrm{Ci}(0.208 \mathrm{TBq})$. Table 6-6 lists the isotopes and the numbers used for calculating the effective $A_{2}$ for the gases and the volatiles in PWR and BWR fuel.
Using the activity from the individual sources (i.e., crud, fines, gases, and volatiles) that contribute to the total source term activity and the effective $A_{2}$ 's of these individual contributions, the effective $A_{2}$ for the total source term is calculated. For PWR fuel rods, the effective $A_{2}$ for the releasable material is $23.36 \mathrm{Ci}(0.865 \mathrm{TBq})$ for normal transport and $27.87 \mathrm{Ci}(1.03 \mathrm{TBq})$ for hypothetical accident conditions. For BWR fuel rods, the effective $A_{2}$ for the releasable material is $14.29 \mathrm{Ci}(0.53 \mathrm{TBq})$ for normal transportation and $20.24 \mathrm{Ci}(0.75 \mathrm{TBq})$ for hypothetical accident conditions. Table 6-7 shows the calculation of these effective $A_{2}$ values for the aerosolized releasable material inside containment vessels holding PWR or BWR fuel at normal transport or hypothetical accident conditions.

Using Equations 2-1 and 2-2 along with the appropriate effective $A_{2}$ values, the allowable release rates $[\mathrm{Ci} / \mathrm{s}]$ can be calculated for the various fuel types and transport conditions. Then, dividing these allowable release rates by the appropriate source term activity concentrations, the allowable upstream leakage rate criteria $\left[\mathrm{cm}^{3} / \mathrm{s}\right]$ at transport conditions can be determined. Table 6-8 gives a summary of the effective $A_{2}$ values, and the corresponding allowable release rates and leakage rates. In Table 6-8, the allowable leakage rate is given in terms of the containment vessel void volume, $\mathrm{V}$, and the number of assemblies in the containment vessel, $\mathrm{N}_{\mathrm{A}}$.

Using the equations given in the last column of Table 6-8 along with the number of fuel assemblies and the containment vessel void volume, the allowable leakage rate under normal transport conditions and hypothetical accident conditions for containers transporting PWR and BWR fuel is calculated. Using these allowable leakage rates and the equation for molecular and continuum flow (Equation 210), the corresponding leak hole diameters are calculated. Then, using these leak hole diameters, the corresponding standard leakage rates are calculated. (Recall that the standard leakage rate is the leakage rate of dry air when it is leaking from 1 atmosphere to 0.01 atmospheres at $298 \mathrm{~K}$.) These calculations are performed for each package and possible contents, and the most restrictive standard leakage rate for a particular contents under normal transport conditions and hypothetical accident conditions is taken as the simplified acceptance standard leakage rate. A summary of the acceptance standard leakage rates for packages transporting PWR or BWR fuel at normal transport conditions and hypothetical accident conditions is given in Table 6-9. 
6. Irradiated Fuel Assemblies

Table 6-6. Calculation of Effective $A_{2}$ Values for the Gases and Volatiles in PWR and BWR Fuel Rods

\begin{tabular}{|c|c|c|c|c|c|c|}
\hline PWR & & & & & & \\
\hline \multirow{2}{*}{$\begin{array}{l}\text { Gaseous } \\
\text { Isotopes }\end{array}$} & \multirow{2}{*}{$\begin{array}{l}\text { Activity } \\
\text { (Ci/MTU) }\end{array}$} & \multirow{2}{*}{$\begin{array}{l}\text { Activity } \\
\text { Fraction, FA }\end{array}$} & \multicolumn{2}{|l|}{$\mathbf{A}_{2}$} & \multirow{2}{*}{$\begin{array}{l}\mathbf{F A} / \mathbf{A}_{2} \\
(1 / \mathrm{Ci})\end{array}$} & \\
\hline & & & (TBq) & (Ci) & & \\
\hline 3-H & 604 & 0.47187 & 40 & 1080 & $4.3828 \times 10^{-4}$ & \\
\hline $129-I$ & 0.031 & $2.4219 \times 10^{-5}$ & unlim. & unlim. & 0 & \\
\hline $81-\mathrm{Kr}$ & $4.44 \times 10^{-7}$ & $3.4688 \times 10^{-10}$ & 40 & 1080 & $3.2218 \times 10^{-13}$ & \\
\hline $85-\mathrm{Kr}$ & 672 & 0.525 & 10 & 270 & $1.9505 \times 10^{-3}$ & \\
\hline \multirow[t]{3}{*}{$127-\mathrm{Xe}$} & $3.31 \times 10^{-17}$ & $2.5859 \times 10^{-20}$ & 4 & 108 & $2.4018 \times 10^{-22}$ & \\
\hline & & & & & $2.3888 \times 10^{-3}$ & $=1 / A_{2}$ \\
\hline & & & & & $\mathrm{A}_{2, \text { gas, }}$ PWR & $=418.6 \mathrm{Ci}$ \\
\hline \multirow{2}{*}{$\begin{array}{l}\text { Volatile } \\
\text { Isotopes }\end{array}$} & \multirow{2}{*}{$\begin{array}{l}\text { Activity } \\
\text { (Ci/MTU) }\end{array}$} & \multirow{2}{*}{$\begin{array}{l}\text { Activity } \\
\text { Fraction , FA }\end{array}$} & \multicolumn{2}{|l|}{$\mathrm{A}_{2}$} & \multirow{2}{*}{$\begin{array}{l}\mathrm{FA} / \mathrm{A}_{2} \\
(1 / \mathrm{Ci})\end{array}$} & \\
\hline & & & $(\mathrm{TBq})$ & $(\mathrm{Ci})$ & & \\
\hline 134-Cs & 29000 & 0.21014 & 0.5 & 13.5 & $1.5622 \times 10^{-2}$ & \\
\hline $135-\mathrm{Cs}$ & 0.369 & $2.6739 \times 10^{-6}$ & 0.9 & 24.3 & $1.1044 \times 10^{-7}$ & \\
\hline 137-Cs & 91400 & 0.66231 & 0.5 & 13.5 & $4.9239 \times 10^{-2}$ & \\
\hline 103-Ru & $1.59 \times 10^{-8}$ & $1.1522 \times 10^{-13}$ & 0.9 & 24.3 & $4.7587 \times 10^{-15}$ & \\
\hline 106-Ru & 17100 & 0.12391 & 0.2 & 5.41 & $2.2988 \times 10^{-2}$ & \\
\hline $89-\mathrm{Sr}$ & $1.09 \times 10^{-5}$ & $7.8986 \times 10^{-11}$ & 0.5 & 13.5 & $5.8720 \times 10^{-12}$ & \\
\hline \multirow[t]{3}{*}{$90-\mathrm{Sr}$} & $4.07 \times 10^{-11}$ & $2.9493 \times 10^{-16}$ & 0.1 & 2.70 & $1.0963 \times 10^{-16}$ & \\
\hline & & & & & $8.7850 \times 10^{-2}$ & $=1 / A_{2}$ \\
\hline & & & & & A2, volatile, PWR & $=11.38 \mathrm{Ci}$ \\
\hline
\end{tabular}


6. Irradiated Fuel Assemblies

Table 6-6. Calculation of Effective $A_{2}$ Values for the Gases and Volatiles in PWR and BWR Fuel Rods, continued

\begin{tabular}{|c|c|c|c|c|c|c|}
\hline BWR & & & & & & \\
\hline \multirow{2}{*}{$\begin{array}{l}\text { Gaseous } \\
\text { Isotopes }\end{array}$} & \multirow{2}{*}{$\begin{array}{l}\text { Activity } \\
\text { (Ci/MTU) }\end{array}$} & \multirow{2}{*}{$\begin{array}{l}\text { Activity } \\
\text { Fraction, FA }\end{array}$} & \multicolumn{2}{|l|}{ A2 } & \multirow{2}{*}{$\begin{array}{l}\mathbf{F A} / \mathbf{A}_{2} \\
(\mathbf{1} / \mathrm{Ci})\end{array}$} & \\
\hline & & & (TBq) & (Ci) & & \\
\hline $3-\mathrm{H}$ & 366 & $5.8280 \times 10^{-2}$ & 40 & 1080 & $5.3963 \times 10^{-5}$ & \\
\hline 132-I & $1.77 \times 10^{-28}$ & $2.8158 \times 10^{-32}$ & 0.4 & 10.8 & $2.6097 \times 10^{-33}$ & \\
\hline $81-\mathrm{Kr}$ & $4.13 \times 10^{-7}$ & $6.5764 \times 10^{-11}$ & 40 & 1080 & $6.0893 \times 10^{-14}$ & \\
\hline $85-\mathrm{Kr}$ & 5910 & 0.94108 & 10 & 270 & $3.4855 \times 10^{-3}$ & \\
\hline \multirow[t]{3}{*}{$127-\mathrm{Xe}$} & $2.58 \times 10^{-17}$ & $4.1083 \times 10^{-21}$ & 4 & 108 & $3.8040 \times 10^{-23}$ & \\
\hline & & & & & \multicolumn{2}{|c|}{$3.5395 \times 10^{-3} \quad=1 / \mathrm{A}_{2}$} \\
\hline & & & & & $\mathrm{A}_{2}$, gas, BWR & $=282.5 \mathrm{Ci}$ \\
\hline \multirow{2}{*}{$\begin{array}{l}\text { Volatile } \\
\text { Isotopes }\end{array}$} & \multirow{2}{*}{$\begin{array}{l}\text { Activity } \\
\text { (Ci/MTU) }\end{array}$} & \multirow{2}{*}{$\begin{array}{l}\text { Activity } \\
\text { Fraction, FA }\end{array}$} & \multicolumn{2}{|l|}{$\mathrm{A}_{2}$} & \multirow{2}{*}{$\begin{array}{l}\mathrm{FA} / \mathrm{A}_{2} \\
(1 / \mathrm{Ci})\end{array}$} & \\
\hline & & & $(\mathrm{TBq})$ & $(\mathrm{Ci})$ & & \\
\hline 134-Cs & 25300 & 0.14134 & 0.5 & 13.5 & $1.0470 \times 10^{-2}$ & \\
\hline $135-\mathrm{Cs}$ & 0.453 & $2.5307 \times 10^{-6}$ & 0.9 & 24.3 & $1.0415 \times 10^{-7}$ & \\
\hline $137-\mathrm{Cs}$ & 83000 & 0.46368 & 0.5 & 13.5 & $3.4347 \times 10^{-2}$ & \\
\hline 103-Ru & $1.11 \times 10^{-8}$ & $6.2011 \times 10^{-14}$ & 0.9 & 24.3 & $2.5519 \times 10^{-15}$ & \\
\hline 106-Ru & 13400 & $7.4860 \times 10^{-2}$ & 0.2 & 5.41 & $1.3837 \times 10^{-2}$ & \\
\hline 89-Sr & $7.49 \times 10^{-6}$ & $4.1844 \times 10^{-11}$ & 0.5 & 13.5 & $3.0995 \times 10^{-12}$ & \\
\hline \multirow[t]{3}{*}{$90-\mathrm{Sr}$} & 57700 & 0.32234 & 0.1 & 2.70 & 0.11939 & \\
\hline & & & & & 0.17804 & $=1 / A_{2}$ \\
\hline & & & & & $A_{2}$, volatile, $B W R$ & $=5.616 \mathrm{Ci}$ \\
\hline
\end{tabular}


Table 6-7. Calculation of Effective $A_{2}$ Values for the Releasable Material in Packages Transporting PWR or BWR Fuel Under Normal Transport Conditions or Under Hypothetical Accident Conditions

\begin{tabular}{|c|c|c|c|c|c|}
\hline PWR & NTC & & & & \\
\hline Source & $\begin{array}{l}\text { Releasable } \\
\text { Activity } \\
\text { (Ci) }\end{array}$ & $\begin{array}{l}\text { Fraction } \\
\text { Activity, FA }\end{array}$ & $\begin{array}{l}\text { Effective } \\
\mathbf{A}_{2} \\
\text { (Ci) }\end{array}$ & $\begin{array}{l}\mathbf{F A} / \mathbf{A 2} \\
(\mathbf{1} / \mathbf{C} \mathbf{i})\end{array}$ & \\
\hline volatiles & 0.429 & $1.0395 \times 10^{-2}$ & 11.383 & $9.1326 \times 10^{-4}$ & \\
\hline gases & 24.3 & 0.83013 & 418.62 & $1.9830 \times 10^{-3}$ & \\
\hline fines & 0.281 & $6.8044 \times 10-3$ & 0.264 & $2.5774 \times 10^{-2}$ & \\
\hline \multirow[t]{3}{*}{ crud } & 6.30 & 0.15266 & 10.8 & $1.4135 \times 10^{-2}$ & \\
\hline & & & & $4.2806 \times 10^{-2}$ & $=1 / A_{2}$ \\
\hline & & & & A2, PWR, NTC & $=23.36 \mathrm{Ci}$ \\
\hline \multirow[t]{2}{*}{ PWR } & HAC & & & & \\
\hline & $\begin{array}{l}\text { Releasable } \\
\text { Activity } \\
\text { (Ci) }\end{array}$ & $\begin{array}{l}\text { Fraction } \\
\text { Activity, FA }\end{array}$ & $\begin{array}{l}\text { Effective } \\
\mathrm{A}_{2} \\
\text { (Ci) }\end{array}$ & $\begin{array}{l}\text { FA/A2 } \\
(\mathbf{1} / \mathbf{C i})\end{array}$ & \\
\hline volatiles & 14.3 & $1.1842 \times 10^{-2}$ & 11.383 & $1.0403 \times 10^{-3}$ & \\
\hline gases & 1140 & 0.94562 & 418.62 & $2.2589 \times 10^{-3}$ & \\
\hline fines & 9.36 & $7.7511 \times 10^{-3}$ & 0.264 & $2.9360 \times 10^{-2}$ & \\
\hline \multirow[t]{3}{*}{ crud } & 42.0 & $3.4780 \times 10^{-2}$ & 710.8 & $3.2204 \times 10^{-3}$ & \\
\hline & & & & $3.5880 \times 10^{-2}$ & $=1 / A_{2}$ \\
\hline & & & & A2, PWR, HAC & $=27.87 \mathrm{Ci}$ \\
\hline
\end{tabular}


Table 6-7. Calculation of Effective $A_{2}$ Values for the Releasable Material in Packages Transporting PWR or BWR Fuel Under Normal Transport Conditions or Under Hypothetical Accident Conditions, continued

\begin{tabular}{|c|c|c|c|c|c|}
\hline BWR & NTC & & & & \\
\hline Source & $\begin{array}{l}\text { Releasable } \\
\text { Activity } \\
\text { (Ci) }\end{array}$ & $\begin{array}{l}\text { Fraction } \\
\text { Activity, FA }\end{array}$ & $\begin{array}{l}\mathbf{A}_{2} \\
(\mathbf{C i})\end{array}$ & $\begin{array}{l}\mathbf{F A} / \mathbf{A} 2 \\
(\mathbf{1} / \mathbf{C i})\end{array}$ & \\
\hline volatiles & 0.237 & $7.4992 \times 10^{-3}$ & 5.617 & $1.3352 \times 10-3$ & \\
\hline gases & 12.4 & 0.39363 & 282.5 & $1.3932 \times 10^{-3}$ & \\
\hline fines & 0.101 & $3.1978 \times 10^{-3}$ & 0.264 & $1.2113 \times 10^{-2}$ & \\
\hline \multirow[t]{3}{*}{ crud } & 18.8 & 0.59567 & 10.8 & $5.5154 \times 10^{-2}$ & \\
\hline & & & & $6.9996 \times 10^{-2}$ & $=1 / A_{2}$ \\
\hline & & & & $A_{2}, \mathrm{BWR}, \mathrm{NTC}$ & $=14.29 \mathrm{Ci}$ \\
\hline \multirow[t]{2}{*}{ BWR } & HAC & & & & \\
\hline & $\begin{array}{l}\text { Releasable } \\
\text { Activity } \\
\text { (Ci) }\end{array}$ & $\begin{array}{l}\text { Fraction } \\
\text { Activity, FA }\end{array}$ & $\begin{array}{l}\mathbf{A}_{2} \\
(\mathbf{C i})\end{array}$ & $\begin{array}{l}\mathbf{F A} / \mathbf{A}_{2} \\
(1 / \mathrm{C} \mathbf{i})\end{array}$ & \\
\hline volatiles & 7.89 & $1.4322 \times 10-2$ & 5.617 & $2.5500 \times 10^{-3}$ & \\
\hline gases & 414 & 0.75204 & 282.5 & $2.6618 \times 10^{-3}$ & \\
\hline fines & 3.37 & $6.1073 \times 10^{-3}$ & 0.264 & $2.3133 \times 10^{-2}$ & \\
\hline \multirow[t]{3}{*}{ crud } & 125 & 0.22752 & 10.8 & $2.1067 \times 10^{-2}$ & \\
\hline & & & & $4.9413 \times 10^{-2}$ & $=1 / A_{2}$ \\
\hline & & & & A2, BWR, HAC & $=20.24 \mathrm{Ci}$ \\
\hline
\end{tabular}


Table 6-8. Effective $A_{2}$ of Releasable Materials and Corresponding Allowable Release Rates and Leakage Rates

\begin{tabular}{|l|l|l|l|l|l|}
\hline Fuel Type & \multirow{2}{*}{$\begin{array}{l}\text { Transport } \\
\text { Conditions }\end{array}$} & \multicolumn{2}{|l|}{ Effective A2 } & $\begin{array}{l}\text { Allowable } \\
\text { Release Rate }\end{array}$ & $\begin{array}{l}\text { Allowable Leakage } \\
\text { Rate, at } \text { Pu }_{\mathbf{u}}\end{array}$ \\
\cline { 3 - 6 } & & $(\mathrm{TBq})$ & $(\mathrm{Ci})$ & $(\mathrm{Ci} / \mathrm{s})$ & $\left(\mathrm{cm}^{3} / \mathrm{s}\right)$ \\
\hline \hline PWR & NTC & 0.865 & 23.36 & $6.49 \times 10^{-9}$ & $\left(1.57 \times 10^{-10}\right) *\left(\mathrm{~V} / \mathrm{N}_{\mathrm{A}}\right)$ \\
\hline PWR & HAC & 1.03 & 27.87 & $4.61 \times 10^{-5}$ & $\left(3.82 \times 10^{-8}\right)^{*}\left(\mathrm{~V} / \mathrm{N}_{A}\right)$ \\
\hline BWR & NTC & 0.529 & 14.29 & $3.96 \times 10^{-9}$ & $\left(1.25 \times 10^{-10}\right) *\left(\mathrm{~V} / \mathrm{N}_{A}\right)$ \\
\hline BWR & HAC & 0.750 & 20.24 & $3.35 \times 10^{-5}$ & $\left(6.08 \times 10^{-8}\right) *\left(\mathrm{~V} / \mathrm{N}_{A}\right)$ \\
\hline
\end{tabular}

where:

$\mathrm{V}$ is the containment vessel void volume $\left[\mathrm{cm}^{3}\right]$ when filled with fuel,

$\mathrm{N}_{\mathrm{A}}$ is the number of fuel assemblies in the containment vessel, and

$\mathbf{P}_{\mathbf{u}}$ is the upstream pressure at operating conditions.

Table 6-9. Acceptance Standard Leakage Rates for Packages Designed to Transport Irradiated Fuel Rods

\begin{tabular}{|l|l|l|}
\hline Fuel Type & \multicolumn{1}{|c|}{ Transport Conditions } & \multicolumn{1}{|c|}{$\begin{array}{c}\text { Standard Leakage } \\
\text { Rate }\left(\mathbf{s t d} \cdot \mathbf{c m}^{\mathbf{3}} / \mathrm{s}\right)\end{array}$} \\
\hline \hline PWR & normal transport conditions & $3.90 \times 10^{-5}$ \\
\hline PWR & hypothetical accident conditions & $1.05 \times 10^{-3}$ \\
\hline BWR & normal transport conditions & $1.19 \times 10^{-5}$ \\
\hline BWR & hypothetical accident conditions & $6.56 \times 10^{-4}$ \\
\hline
\end{tabular}




\section{Contents: Liquid Byproduct or Special Nuclear Materials}

In this section, representative acceptance standard leakage rates for packages designed to transport radioactive liquids are developed. Transported radioactive liquids are typically contaminated reactor water, other aqueous solutions of radionuclides, or organic solvents containing radioactivity. In the following analysis, leakage of an aerosol made of liquid droplets suspended in the fill gas is neglected since it is assumed that the volume of fill gas is a very small fraction of the total containment vessel volume.

\subsection{Measured Concentration in the Leakage Path}

For the case of liquid radioactive contents, the releasable material is the bulk liquid. The concentration of the liquid $\left(\mathrm{Ci} / \mathrm{cm}^{3}\right)$ is the activity density of the liquid and must be measured or calculated based on the activity of the constituents. The activity concentration is the product of the liquid specific activity ( $\mathrm{Ci} / \mathrm{g}$ ) and the liquid mass density $\left(\mathrm{g} / \mathrm{cm}^{3}\right)$.

\subsection{Characteristics of Packages that Transport Liquid Nuclear Materials}

If the radioactive contents provides no appreciable heat load and the package is loaded at a pressure of one atmosphere, the maximum normal operating temperature is estimated as $150^{\circ} \mathrm{F}\left(65.5^{\circ} \mathrm{C}\right)$. As a conservative approach, the maximum normal operating pressure is estimated as 1.9 atmospheres to account for the temperature increase and the water vapor pressure.

During the hypothetical accident conditions fire test, the contents should not be above $500^{\circ} \mathrm{F}\left(260^{\circ} \mathrm{C}\right)$ since this is the limit of the typically employed polymeric o-rings. Therefore, it is conservative to assume that the maximum containment vessel pressure during the hypothetical accident conditions is $\mathbf{4 8 . 2}$ atmospheres as a result of the temperature increase and the water vapor pressure.

\subsection{Acceptance Criteria for Leakage Tests}

The allowable liquid leakage rate from packages designed to transport liquid radionuclides is:

\section{Equation 7-1}

$L_{i}=\frac{R_{i}}{C_{i}}$ where:

$\mathrm{L}_{\mathrm{i}}$ is the allowable leakage rate $\left[\mathrm{cm}^{3} / \mathrm{s}\right]$,

$\mathrm{R}_{\mathrm{i}}$ is the allowable release rate $[\mathrm{Ci} / \mathrm{s}]$,

$\mathrm{C}_{\mathrm{i}}$ is the activity concentration of the radioactive liquid $\left[\mathrm{Ci} / \mathrm{cm}^{3}\right]$, where $\mathrm{i}=\mathrm{N}$ for normal transport conditions or $\mathrm{i}=\mathrm{A}$ for hypothetical accident conditions.

Since liquids are relatively incompressible when subject to moderate changes in temperature and pressure, in the following analysis it is assumed that $\mathrm{C}_{\mathrm{N}}=\mathrm{C}_{\mathrm{A}}=\mathrm{C}$. The activity concentration can also be expressed as the product of the fluid mass density, $\rho\left(\mathrm{g} / \mathrm{cm}^{3}\right)$, and the fluid specific activity, $\mathrm{S}_{\mathrm{A}}(\mathrm{Ci} / \mathrm{g})$.

For normal transport conditions,

$R_{\mathrm{N}}=10^{-6} \mathrm{~A}_{2} / \mathrm{hr}=2.78 \times 10^{-10} \mathrm{~A}_{2} / \mathrm{s}$, and the allowable leakage rate becomes:

\section{Equation 7-2}

$$
\mathrm{L}_{\mathrm{N}}=\frac{2.78 \times 10^{-10} \mathrm{~A}_{2}}{\rho \mathrm{S}_{\mathrm{A}}}(1 / \mathrm{s}),
$$

where:

$\mathrm{L}_{\mathrm{N}}$ is the allowable leakage rate at normal transport conditions $\left[\mathrm{cm}^{3} / \mathrm{s}\right]$,

$p \quad$ is the mass density of the liquid $\left[\mathrm{g} / \mathrm{cm}^{3}\right]$, and

$\mathrm{S}_{\mathrm{A}}$ is the specific activity of the liquid [Ci/g].

For liquid leaking from a containment vessel, the flow regime is laminar, and the allowable leakage rate under normal transport conditions $\left(\mathrm{L}_{\mathrm{N}}\right)$ can be expressed as:

Equation 7-3

$$
L_{N}=\frac{2.49 \times 10^{6} D_{N}^{4}\left(P_{u, N}-P_{d, N}\right)}{a \mu},
$$

where:

DN is the leak hole diameter that corresponds to normal transport conditions [cm], 
$\mathrm{P}_{\mathrm{u}, \mathrm{N}}$ is the upstream pressure under normal transport conditions [atm],

$P_{\mathrm{d}, \mathrm{N}}$ is the downstream pressure under normal transport conditions [atm],

a is the length of the leak hole $[\mathrm{cm}]$, and

$\mu \quad$ is the liquid viscosity [cP].

As a result of the relative incompressibility of liquids, no pressure correction is needed for Equation 7-3 to obtain the upstream volumetric flow rate. Equating Equation 7-2 to Equation 7-3 and solving for the leak hole diameter gives:

\section{Equation 7-4}

$$
D_{N}=\left(\frac{a \mu A_{2}}{\rho S_{A}\left(P_{u, N}-P_{d, N}\right)}\right)^{0.25}\left(1.028 \times 10^{-4}\right)
$$

The acceptance standard leakage rate is the flow rate of dry air through the above calculated leak hole diameter under standard leak test conditions. For the flow of dry air through the above calculated leak hole diameter at standard leak test conditions, the laminar and molecular flow equation can be used (as long as the standard leakage rate is less than one $\mathrm{std} \cdot \mathrm{cm}^{3} / \mathrm{s}$ ) and the standard leakage rate that corresponds to the release rate at the normal transport conditions $\left(\mathrm{L}_{\text {std, }} \mathrm{N}\right)$ can be shown to be:

\section{Equation 7-5a}

$$
\begin{aligned}
L_{\text {std }, \mathrm{N}}= & \left(7.516 \times 10^{-9}\right)\left(\frac{\mathrm{a} \mu A_{2}}{\rho S_{A}\left(P_{u, N}-P_{d, N}\right)}\right)+ \\
& \left(\frac{1.314 \times 10^{-8}}{a}\right)\left(\frac{a \mu A_{2}}{\rho S_{A}\left(P_{u, N}-P_{d, N}\right)}\right)^{0.75},
\end{aligned}
$$

where:

$\mathrm{L}_{\text {std, }} \mathbf{N}$ is the acceptance standard leakage rate that corresponds to the allowable leakage rate at normal transport conditions [std $\cdot \mathrm{cm}^{3} / \mathrm{s}$ ],

$\mu \quad$ is the viscosity of the liquid radioactive contents at normal transport conditions [cP],

a is the length of the leak hole $[\mathrm{cm}]$, and

$\mathrm{S}_{\mathrm{A}} \quad$ is the specific activity of the liquid radioactive contents [Ci/g].
For the case when $\mathrm{a}=0.25 \mathrm{~cm}$ and $\mathrm{P}_{\mathrm{d}, \mathrm{N}}=1 \mathrm{~atm}$, and for an aqueous-based liquid where $\mu=1 \mathrm{cP}$ and $\rho=1 \mathrm{~g} / \mathrm{cm}^{3}$, then Equation 7-5a becomes:

\section{Equation 7-5b}

$$
\begin{aligned}
L_{\text {std }, N}= & \left(1.879 \times 10^{-9}\right)\left(\frac{A_{2}}{S_{A}\left(P_{u, N}-1\right)}\right)+ \\
& \left(1.858 \times 10^{-8}\right)\left(\frac{A_{2}}{S_{A}\left(P_{u, N}-1\right)}\right)^{0.75}
\end{aligned}
$$

The same procedure can be followed for calculating the standard leakage rate that corresponds to the hypothetical accident conditions. The allowable leakage rate under hypothetical accident conditions is:

\section{Equation 7-6}

$$
\mathrm{L}_{\mathrm{A}}=\frac{\mathrm{R}_{\mathrm{A}}}{\mathrm{C}}=\frac{\mathrm{A}_{2} / \text { week }}{\rho \mathrm{S}_{\mathrm{A}}}=\frac{1.653 \times 10^{-6} \mathrm{~A}_{2}}{\rho \mathrm{S}_{\mathrm{A}}}(1 / \mathrm{s}) .
$$

Equating this allowable leakage rate to the laminar flow equation and solving for the leak hole diameter gives:

\section{Equation 7-7}

$D_{A}=\left[\frac{a \mu A_{2}}{\rho S_{A}\left(P_{u, A}-P_{d, A}\right)}\right]^{0.25}\left(9.027 \times 10^{-4}\right)$,

where:

$\mathrm{D}_{\mathrm{A}}$ is the leak hole diameter that corresponds to the hypothetical accident conditions [cm],

$\rho \quad$ is the mass density of the liquid radioactive contents $\left[\mathrm{g} / \mathrm{cm}^{3}\right]$

a is the length of the leak hole $[\mathrm{cm}]$,

$\mathrm{S}_{\mathrm{A}}$ is the specific activity of the liquid radioactive contents [Ci/g],

$P_{u, A}$ is the upstream pressure under the hypothetical accident conditions [atm] , and

$P_{d, A}$ is the downstream pressure under the hypothetical accident conditions [atm].

Substituting the expression for the leak hole diameter given in Equation 7-7 into the equation for laminar and molecular flow under the standard leak test conditions, assuming a 
leak hole length of $0.25 \mathrm{~cm}$, a liquid density of $1 \mathrm{~g} / \mathrm{cm}^{3}$, a downstream pressure $\left(\mathrm{P}_{\mathrm{d}, \mathrm{A}}\right)$ of 1.0 atmosphere, and a liquid viscosity of $1 \mathrm{cP}$, the acceptance standard leakage rate that corresponds to the hypothetical accident conditions can be given as:

\section{Equation $7-8$}

$L_{s c d, A}=\left(4.469 \times 10^{-5}\right)\left(\frac{A_{2}}{\left(P_{u, A}-1\right) S_{A}}\right)+\left(1.258 \times 10^{-5} \cdot\left(\frac{A_{2}}{\left(P_{u, A}-1\right) S_{A}}\right)^{0.75}\right.$

where:

$\mathrm{L}_{\text {std, } \mathrm{A}}$ is the acceptance standard leakage rate that corresponds to the hypothetical accident conditions $\left[\mathrm{std} \cdot \mathrm{cm}^{3} / s\right]$,
$\mathrm{P}_{\mathrm{u}, \mathrm{A}}$ is the upstream pressure under the hypothetical accident conditions [atm], and

$\mathrm{S}_{\mathrm{A}} \quad$ is the specific activity of the radioactive liquid $[\mathrm{Ci} / \mathrm{g}]$.

Using the operating pressures given in Section 7.2 for packages used to transport liquid radioactive materials, the acceptance standard leakage rates that correspond to both normal transport conditions and hypothetical accident conditions can be calculated for various $A_{2} / S_{A}$ ratios. Table 7-1 summarizes these acceptance leakage rates. Note that if the vapor pressure of the liquid transported is significantly different from that of water, the transport pressures, and the corresponding standard leakage rates, would need to be adjusted accordingly.

Table 7-1. $A_{2} / S_{A}$ and Corresponding Acceptance Standard Leakage Rates for Packages Designed to Transport Radioactive Liquids (with $P_{\mathrm{u}, \mathrm{N}} \leq 1.9$ atm and $\mathrm{P}_{\mathrm{u}, \mathrm{A}} \leq \mathbf{4 8 . 2} \mathrm{atm}$ )

\begin{tabular}{|c|c|c|}
\hline $\mathbf{A}_{2} / \mathbf{S}_{\mathbf{A}}(\mathrm{g})$ & $\begin{array}{l}\mathbf{L}_{\text {std, } N \text {,standard leakage rate that }} \\
\text { corresponds to normal transport } \\
\text { conditions }\left(\mathrm{std} \cdot \mathrm{cm}^{3} / \mathrm{s} \text { ) }\right.\end{array}$ & $\begin{array}{l}\mathrm{L}_{\text {std,A, }}, \text { standard leakage rate that } \\
\text { corresponds to hypothetical accident } \\
\text { conditions (std } \cdot \mathrm{cm}^{3} / \mathrm{s} \text { ) }\end{array}$ \\
\hline$\geq 2$ & $\leq 3.79 \times 10^{-8}$ & $\leq 3.06 \times 10^{-6}$ \\
\hline$\geq 20$ & $\leq 2.31 \times 10^{-7}$ & $\leq 2.55 \times 10^{-5}$ \\
\hline$\geq 3 \times 10^{2}$ & $\leq 2.07 \times 10^{-6}$ & $\leq 3.34 \times 10^{-4}$ \\
\hline$\geq 4 \times 10^{3}$ & $\leq 1.84 \times 10^{-5}$ & $\leq 4.13 \times 10^{-3}$ \\
\hline$\geq 4 \times 10^{4}$ & $\leq 1.40 \times 10^{-4}$ & $\leq 3.89 \times 10^{-2}$ \\
\hline$\geq 4 \times 10^{5}$ & $\leq 1.15 \times 10^{-3}$ & $\leq 3.89 \times 10^{-1}$ \\
\hline$\geq 4 \times 10^{6}$ & $\leq 1.01 \times 10^{-2}$ & $\leq 3.84$ \\
\hline$\geq 4 \times 10^{7}$ & $\leq 9.36 \times 10^{-2}$ & $\leq 38.2$ \\
\hline$\geq 4 \times 10^{8}$ & $\leq 8.91 \times 10^{-1}$ & $\leq 380$ \\
\hline
\end{tabular}



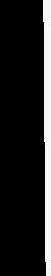


\section{Conclusions}

Table 8-1 summarizes representative standard leakage rate acceptance criteria for Type B packages with various contents types. The information in this table is a compilation of the representative acceptance leakage rate criteria calculated in the individual sections of this report.

notes:

(1) NA indicates that the entry does not apply for the given contents type.

(2) $\mathrm{S}_{\mathrm{A}}$ is the specific activity of the releasable contents $[\mathrm{Ci} / \mathrm{g}]$

(3) "Leak tight" corresponds to a standard leakage rate of $10^{-7} \mathrm{std} \cdot \mathrm{cm}^{3} / \mathrm{s}$.

(4) NTC denotes normal transport conditions.

(5) HAC denotes hypothetical accident conditions.

Table 8-1. Summary of Representative Acceptance Standard Leakage Rates for Type B Packages with Various Content Types

\begin{tabular}{|c|c|c|c|c|c|c|}
\hline \multirow[b]{3}{*}{ Container Contents } & \multicolumn{6}{|c|}{ Standard Leakage Rates $\left(\mathrm{std} \cdot \mathrm{cm}^{3} / \mathrm{s}\right.$ ) } \\
\hline & \multicolumn{2}{|c|}{$\begin{array}{l}\text { Category I } \\
\left(>3000 A_{2}\right)\end{array}$} & \multicolumn{2}{|c|}{$\begin{array}{l}\text { Category II } \\
\left(>30 \mathbf{A}_{2} \&<3000 \mathrm{~A}_{2}\right)\end{array}$} & \multicolumn{2}{|c|}{$\begin{array}{l}\text { Category III } \\
(<30 \mathrm{A2})\end{array}$} \\
\hline & NTC & HAC & NTC & HAC & NTC & HAC \\
\hline \multicolumn{7}{|l|}{ Powders: } \\
\hline${ }^{239} \mathrm{PuO}_{2}$ & $3.02 \times 10^{-6}$ & $1.77 \times 10^{-2}$ & $3.01 \times 10^{-5}$ & 0.164 & $5.81 \times 10^{-4}$ & 2.94 \\
\hline $240 \mathrm{PuO}_{2}$ & $7.64 \times 10^{-7}$ & $4.63 \times 10^{-3}$ & $7.66 \times 10^{-6}$ & $4.34 \times 10^{-2}$ & $1.51 \times 10^{-4}$ & 0.786 \\
\hline${ }^{241} \mathrm{PuO}_{2}$ & leak tight & $4.51 \times 10^{-4}$ & $7.15 \times 10^{-7}$ & $4.34 \times 10^{-3}$ & $1.43 \times 10^{-5}$ & $8.02 \times 10^{-2}$ \\
\hline${ }^{233} \mathrm{UO}_{2}$ & $1.15 \times 10^{-4}$ & 0.603 & $1.10 \times 10^{-3}$ & 5.50 & $2.04 \times 10^{-2}$ & 97.5 \\
\hline $\mathrm{UO}_{2} \mathrm{w} / 95 \%{ }^{235} \mathrm{UO}_{2}$ & $1.33 \times 10^{-2}$ & 64.3 & 0.123 & $5.81 \times 10^{2}$ & 2.19 & $1.02 \times 10^{4}$ \\
\hline $\mathrm{UO}_{2} \mathrm{w} / 93 \%{ }^{235} \mathrm{UO}_{2}$ & $1.74 \times 10^{-2}$ & 83.7 & 0.161 & $7.57 \times 10^{2}$ & 2.87 & $1.33 \times 10^{4}$ \\
\hline $\mathrm{UO}_{2} \mathrm{w} / 90 \%{ }^{235} \mathrm{UO}_{2}$ & $2.10 \times 10^{-2}$ & $1.02 \times 10^{2}$ & 0.194 & $9.13 \times 10^{2}$ & 3.46 & $1.60 \times 10^{4}$ \\
\hline $\mathrm{UO}_{2}$ w/ $50 \%{ }^{235} \mathrm{UO}_{2}$ & $4.94 \times 10^{-2}$ & $2.34 \times 10^{2}$ & 0.453 & $2.12 \times 10^{3}$ & 8.04 & $3.73 \times 10^{4}$ \\
\hline $\mathrm{UO}_{2}$ w/ $35 \%{ }^{235} \mathrm{UO}_{2}$ & $6.18 \times 10^{-2}$ & $2.93 \times 10^{2}$ & 0.566 & $2.66 \times 10^{3}$ & 10.1 & $4.66 \times 10^{4}$ \\
\hline $\mathrm{UO}_{2} \mathrm{w} / 20 \%{ }^{235} \mathrm{UO}_{2}$ & 0.125 & $5.88 \times 10^{2}$ & 1.14 & $5.67 \times 10^{3}$ & 20.2 & $9.33 \times 10^{4}$ \\
\hline $\mathrm{UO}_{2} \mathrm{w} / 10 \%{ }^{235} \mathrm{UO}_{2}$ & 0.260 & $1.23 \times 10^{3}$ & 2.38 & $3.46 \times 10^{4}$ & 42.2 & $1.95 \times 10^{5}$ \\
\hline $\mathrm{UO}_{2} \mathrm{w} / \leq 5 \%{ }^{235} \mathrm{UO}_{2}$ & unlim. & unlim. & unlim. & unlim. & unlim. & unlim. \\
\hline${ }^{233} \mathrm{U}$ & $1.00 \times 10^{-4}$ & 0.529 & $9.63 \times 10^{-4}$ & 4.83 & $1.79 \times 10^{-2}$ & 85.6 \\
\hline $\mathrm{Uw} / 95 \%{ }^{235} \mathrm{U}$ & $1.17 \times 10^{-2}$ & 56.6 & 0.108 & $5.12 \times 10^{2}$ & 1.94 & $9.01 \times 10^{3}$ \\
\hline $\mathrm{U} w / 93 \%{ }^{235} \mathrm{U}$ & $1.53 \times 10^{-2}$ & 73.7 & 0.141 & $6.65 \times 10^{2}$ & 2.52 & $1.17 \times 10^{4}$ \\
\hline $\mathrm{Uw} / 90 \% 235 \mathrm{U}$ & $1.85 \times 10^{-2}$ & 88.9 & 0.170 & $8.04 \times 10^{2}$ & 3.04 & $1.41 \times 10^{4}$ \\
\hline $\mathrm{U} w / 50 \% 235 \mathrm{U}$ & $4.32 \times 10^{-2}$ & $2.06 \times 10^{2}$ & 0.398 & $1.87 \times 10^{3}$ & 7.07 & $3.28 \times 10^{4}$ \\
\hline
\end{tabular}


Table 8-1. Summary of Representative Acceptance Standard Leakage Rates for Type B Packages with Various Content Types, continued

\begin{tabular}{|c|c|c|c|c|c|c|}
\hline \multirow[b]{3}{*}{ Container Contents } & \multicolumn{6}{|c|}{ Standard Leakage Rates $\left(\mathrm{std} \cdot \mathrm{cm}^{3} / \mathrm{s}\right.$ ) } \\
\hline & \multicolumn{2}{|c|}{$\begin{array}{l}\text { Category I } \\
(>3000 \mathrm{A2})\end{array}$} & \multicolumn{2}{|c|}{$\begin{array}{l}\text { Category II } \\
\left(>30 \mathrm{~A}_{2} \&<3000 \mathrm{~A}_{2}\right)\end{array}$} & \multicolumn{2}{|c|}{$\begin{array}{l}\text { Category III } \\
\left(<30 \mathrm{A2}_{2}\right)\end{array}$} \\
\hline & NTC & HAC & NTC & HAC & NTC & HAC \\
\hline \multicolumn{7}{|l|}{ Powders, continued: } \\
\hline $\mathrm{Uw} / 35 \% 235 \mathrm{U}$ & $5.44 \times 10^{-2}$ & $2.58 \times 10^{2}$ & 0.498 & $2.33 \times 10^{3}$ & 8.85 & $4.11 \times 10^{4}$ \\
\hline $\mathrm{Uw} / 20 \% 235 \mathrm{U}$ & 0.109 & $5.17 \times 10^{2}$ & 1.00 & $4.66 \times 10^{3}$ & 17.8 & $8.21 \times 10^{4}$ \\
\hline $\mathrm{Uw} / 10 \% 235 \mathrm{U}$ & 0.230 & $1.07 \times 10^{3}$ & 2.09 & $9.73 \times 10^{3}$ & 37.0 & $1.71 \times 10^{5}$ \\
\hline $\mathrm{Uw} / \leq 5 \% 235 \mathrm{U}$ & unlim. & unlim. & unlim. & unlim. & unlim. & unlim. \\
\hline \multicolumn{7}{|l|}{ Dispersible Solids: } \\
\hline $\mathrm{A}_{2} / \mathrm{S}_{\mathrm{A}} \geq 1 \times 10^{-8}$ & leaktight & leaktight & leaktight & leaktight & leaktight & leaktight \\
\hline $\mathrm{A}_{2} / \mathrm{S}_{\mathrm{A}} \geq 1 \times 10^{-7}$ & leaktight & leaktight & leaktight & leaktight & leaktight & $8.33 \times 10^{-7}$ \\
\hline$A_{2} / S_{A} \geq 1 \times 10^{-6}$ & leaktight & leaktight & leaktight & leaktight & $6.48 \times 10^{-7}$ & $9.66 \times 10^{-6}$ \\
\hline $\mathrm{A}_{2} / \mathrm{S}_{\mathrm{A}} \geq 1 \times 10^{-5}$ & leaktight & leaktight & $1.22 \times 10^{-7}$ & $7.27 \times 10^{-7}$ & $7.52 \times 10^{-6}$ & $1.10 \times 10^{-4}$ \\
\hline $\mathrm{A}_{2} / \mathrm{S}_{\mathrm{A}} \geq 1 \times 10^{-4}$ & leaktight & leaktight & $1.34 \times 10^{-6}$ & $8.44 \times 10^{-6}$ & $8.57 \times 10^{-5}$ & $1.21 \times 10^{-3}$ \\
\hline $\mathrm{A}_{2} / \mathrm{S}_{\mathrm{A}} \geq 1 \times 10^{-3}$ & leaktight & $7.45 \times 10^{-7}$ & $1.47 \times 10^{-5}$ & $9.61 \times 10^{-5}$ & $9.45 \times 10^{-4}$ & $1.28 \times 10^{-2}$ \\
\hline $\mathrm{A}_{2} / \mathrm{S}_{\mathrm{A}} \geq 1 \times 10^{-2}$ & $8.32 \times 10^{-7}$ & $8.12 \times 10^{-6}$ & $1.58 \times 10^{-4}$ & $1.06 \times 10^{-3}$ & $1.01 \times 10^{-2}$ & $1.33 \times 10^{-1}$ \\
\hline $\mathrm{A}_{2} / \mathrm{S}_{\mathrm{A}} \geq 1 \times 10^{-1}$ & $9.14 \times 10^{-6}$ & $8.86 \times 10^{-5}$ & $1.66 \times 10^{-3}$ & $1.13 \times 10^{-2}$ & $1.05 \times 10^{-1}$ & 1.36 \\
\hline $\mathrm{A}_{2} / \mathrm{S}_{\mathrm{A}} \geq 1$ & $9.88 \times 10^{-5}$ & $9.37 \times 10^{-4}$ & $1.72 \times 10^{-2}$ & $1.17 \times 10^{-1}$ & 1.07 & $1.38 \times 10^{1}$ \\
\hline $\mathrm{A}_{2} / \mathrm{S}_{\mathrm{A}} \geq 1 \times 10^{1}$ & $1.04 \times 10^{-3}$ & $9.72 \times 10^{-3}$ & $1.75 \times 10^{-1}$ & 1.20 & $1.09 \times 10^{1}$ & $1.39 \times 10^{2}$ \\
\hline $\mathrm{A}_{2} / \mathrm{S}_{\mathrm{A}} \geq 1 \times 10^{2}$ & $1.08 \times 10^{-2}$ & $9.94 \times 10^{-2}$ & 1.77 & $1.22 \times 10^{1}$ & $1.10 \times 10^{2}$ & $>1000$ \\
\hline $\mathrm{A}_{2} / \mathrm{S}_{\mathrm{A}} \geq 1 \times 10^{3}$ & $1.10 \times 10^{-1}$ & 1.01 & $1.78 \times 10^{1}$ & $1.22 \times 10^{2}$ & $>1000$ & $>1000$ \\
\hline $\mathrm{A}_{2} / \mathrm{S}_{\mathrm{A}} \geq 1 \times 10^{4}$ & 1.11 & $1.01 \times 10^{1}$ & $1.79 \times 10^{2}$ & $>1000$ & $>1000$ & $>1000$ \\
\hline $\mathrm{A}_{2} / \mathrm{S}_{\mathrm{A}} \geq 1 \times 10^{5}$ & $11.13 \times 10^{1}$ & $1.02 \times 10^{2}$ & $>1000$ & $>1000$ & $>1000$ & $>1000$ \\
\hline $\mathrm{A}_{2} / \mathrm{S}_{\mathrm{A}} \geq 1 \times 10^{6}$ & $113 \times 10^{2}$ & $>1000$ & $>1000$ & $>1000$ & $>1000$ & $>1000$ \\
\hline $\mathrm{A}_{2} / \mathrm{S}_{\mathrm{A}} \geq 1 \times 10^{7}$ & $>1000$ & $>1000$ & $>1000$ & $>1000$ & $>1000$ & $>1000$ \\
\hline Nondispersible Solids: & \multicolumn{6}{|l|}{ See Text } \\
\hline
\end{tabular}


Table 8-1. Summary of Representative Acceptance Standard Leakage Rates for Type B Packages with Various Content Types, continued

\begin{tabular}{|c|c|c|c|c|c|c|}
\hline \multirow[b]{3}{*}{ Container Contents } & \multicolumn{6}{|c|}{ Standard Leakage Rates $\left(\mathrm{std} \cdot \mathrm{cm}^{3} / \mathrm{s}\right.$ ) } \\
\hline & \multicolumn{2}{|l|}{$\begin{array}{l}\text { Category I } \\
(>3000 \text { A2 })\end{array}$} & \multicolumn{2}{|c|}{$\begin{array}{l}\text { Category II } \\
\left(>\mathbf{3 0} \mathbf{A 2}_{2} \&<3000 \mathrm{~A}_{2}\right)\end{array}$} & \multicolumn{2}{|c|}{$\begin{array}{l}\text { Category III } \\
\left(<30 \mathbf{A}_{2}\right)\end{array}$} \\
\hline & NTC & HAC & NTC & HAC & NTC & HAC \\
\hline \multicolumn{7}{|l|}{ Gases: } \\
\hline Tritium & leak tight & $2.40 \times 10^{-5}$ & NA & NA & NA & NA \\
\hline Krypton-85 & leak tight & $9.85 \times 10^{-5}$ & NA & NA & NA & NA \\
\hline $\begin{array}{l}\text { Gaseous Mix w/ } \mathrm{A}_{2}=0.4 \mathrm{Ci} \& \\
\text { activity density } \geq 2.846 \mathrm{Ci} / \mathrm{cm}^{3}\end{array}$ & leak tight & leak tight & NA & NA & NA & NA \\
\hline \multicolumn{7}{|l|}{ Irradiated Fuel Assemblies: } \\
\hline PWR fuel & $3.90 \times 10^{-5}$ & $1.05 \times 10^{-3}$ & NA & NA & NA & NA \\
\hline BWR fuel & $1.19 \times 10^{-5}$ & $6.56 \times 10^{-4}$ & NA & NA & NA & NA \\
\hline \multicolumn{7}{|l|}{ Liquids: } \\
\hline $\mathrm{A}_{2} / \mathrm{S}_{\mathrm{A}} \geq 2$ & leak tight & $\leq 3.06 \times 10^{-6}$ & NA & NA & NA & NA \\
\hline $\mathrm{A}_{2} / \mathrm{S}_{\mathrm{A}} \geq 20$ & $\leq 2.31 \times 10^{-7}$ & $\leq 2.55 \times 10^{-5}$ & NA & NA & NA & NA \\
\hline $\mathrm{A}_{2} / \mathrm{S}_{\mathrm{A}} \geq 3 \times 10^{2}$ & $\leq 2.07 \times 10^{-6}$ & $\leq 3.34 \times 10^{-4}$ & NA & NA & NA & NA \\
\hline $\mathrm{A}_{2} / \mathrm{S}_{\mathrm{A}} \geq 4 \times 10^{3}$ & $\leq 1.84 \times 10^{-5}$ & $\leq 4.13 \times 10^{-3}$ & NA & NA & NA & NA \\
\hline $\mathrm{A}_{2} / \mathrm{S}_{\mathrm{A}} \geq 4 \times 10^{4}$ & $\leq 1.40 \times 10^{-4}$ & $\leq 3.89 \times 10^{-2}$ & NA & NA & NA & NA \\
\hline $\mathrm{A}_{2} / \mathrm{S}_{\mathrm{A}} \geq 4 \times 10^{5}$ & $\leq 1.15 \times 10^{-3}$ & $\leq 3.89 \times 10^{-1}$ & NA & NA & NA & NA \\
\hline $\mathrm{A}_{2} / \mathrm{S}_{\mathrm{A}} \geq 4 \times 10^{6}$ & $\leq 1.01 \times 10^{-2}$ & $\leq 3.84$ & NA & NA & NA & NA \\
\hline $\mathrm{A}_{2} / \mathrm{S}_{\mathrm{A}} \geq 4 \times 10^{7}$ & $\leq 9.36 \times 10^{-2}$ & $\leq 38.2$ & NA & NA & NA & NA \\
\hline $\mathrm{A} 2 / \mathrm{S}_{\mathrm{A}} \geq 4 \times 10^{8}$ & $\leq 8.91 \times 10^{-1}$ & $\leq 380$ & NA & NA & NA & NA \\
\hline
\end{tabular}




\section{References}

[1] J.A. Andersen. "Bounding Assessment Method for Correlating Measured Gas Leaks to the Possible Loss of Particulate Contents from Radioactive Materials Packages." Nuclear Technology 72 (1986): 75.

[2] H.J. Bomelburg. Estimation of Gas Leak Rates Through Very Small Orifices. BNWL-2223. Battelle Pacific Northwest Laboratories, Richland, WA, February 1977.

[3] J.D. Colton and R.R. Pettejohn. "Leak Rate Tests on PC-1 Plutonium Product Cans Sealed by Welding." Final Report September 1978-January 1979, Poulter Laboratory, SRI International, April 1979.

[4] W.D. Curren and R.D. Bond. "Leakage of Radioactive Powders from Containers." In Proceedings of the 7th Int. Symp. on Packaging and Transport of Radioactive Material, 1980.

D.C. Drennen, et al. "Study of Plutonia Leak Rates From Simulated Container Leaks." In Proceedings of the 5th Int. Symp. on Packaging and Transport of Radioactive Material, May 7-12, 1978, Sahara Hotel, Las Vegas, NV, USA.

[6] L.E. Fischer. Calculations of Test Leakage Rate for a Spent Fuel Cask. UCRL-JC-106203. Lawrence Livermore National Laboratory, January 1991.

[7] W.H. Hedley, et al. "Flow of Gases and Liquids through Ultrafine Capillaries Having Diameters between 1.5 and 60 Micrometers." J. Rheology 22, no. 2 (1978): 91 .

[8] R.L. Kissling and P.H. Gross. J. Phys. Chem. 74 (1970): 308 .

[9] T.T. Kodas and A. Sood. "Submicron Alumina Powder Production by a Turbulent Flow Aerosol Process. " Powder Technology 50 (1987): 47.

[10] D.A.V. Morton et al. "Experimental Study of the Transport of Non-Spherical Aerosol Particles through Micron-Size Capillary Leak-Paths." Paper presented at the AAAR Annual Meeting, San Francisco, October 1992.
[11] P.C. Owzarski et al. Analysis of Particulate Transmission Through Small Openings Resulting from Container Stresses. NUREG/CR-0958, PNL3067. Battelle-Pacific Northwest Laboratory, February 1980.

[12] R.H. Perry and C.H. Chilton. Chemical Engineer's Handbook. 5th Edition. New York: McGraw-Hill Book Company, 1973.

[13] S.E. Pratsinis et al. "Design of Laminar Flow Condensers for Production of Monodisperse Aerosols." Ind. Eng. Chem. Res. 27 (1988): 105.

[14] L. Prandtl \& O.G. Tietjens. Applied Hydro and Aero-Mechanics, 16-18. New York: Dover Pubs., 1934.

[15] Title 10 of the United States Code of Federal Regulations Parts 20, 49, and 71.

[16] ANSI N14.5-1987. "American National Standard for Radioactive Materials Leakage Teats on Packages for Shipment."

[17] "Plutonium Air Transportable Package Model PAT-1." Safety Analysis Report, Office of Nuclear Material Safety and Safeguards, U.S. Nuclear Regulatory Commission, June 1978.

[18] Directory of Certificates of Compliance for Radioactive Materials Packages. NUREG-0383, Vol. 2, Revision 15. U.S. Nuclear Regulatory Commission, Office of Nuclear Materials Safety and Safeguards, October, 1992.

[19] R.P. Sandoval et al. Estimate of CRUD Contribution to Shipping Cask Containment Requirements. SAND88-1358. Sandia National Laboratories, 1991.

[20] T.L. Sanders et al. A Method for Determining the Spent-F uel Contribution to Transport Cask Containment Requirements. SAND90-2406. Sandia National Laboratories, 1992.

[21] L.C. Schwendiman et al. Study of Plutonium Oxide Leak Rates from Shipping Containers, Quarterly Progress Report, October 1, 1976 - December 21, 1976. BNWL-2260-1. Battelle, Pacific Northwest Labs, Richland, WA. 
[22] L.C. Schwendiman et al. Study of Plutonium Oxide Leak Rates from Shipping Containers, Quarterly Progress Report, January 1, 1977 - March 31, 1977. BNWL-2260-2. Battelle, Pacific Northwest Labs, Richland, WA.

[23] L.C. Schwendiman et al. Study of Plutonium Oxide Leak Rates from Shipping Containers, Quarterly Progress Report, April 1, 1977 - June 30, 1977. BNWL-2260-3. Battelle, Pacific Northwest Labs, Richland, WA.

[24] L.C. Schwendiman et al. Study of Plutonium Oxide Leak Rates from Shipping Containers, Quarterly Progress Report, July 1, 1977 - September 30, 1977. BNWL-2260-4. Battelle, Pacific Northwest Labs, Richland, WA.

[25] L.C. Schwendiman et al. Study of Plutonium Oxide Leak Rates from Shipping Containers, Quarterly Progress Report, October 1, 1977 - December 31, 1977. BNWL-2260-5. Battelle, Pacific Northwest Labs, Richland, WA.

[26] L.C. Schwendiman et al. Study of Plutonium Oxide Leak Rates from Shipping Containers, Quarterly Progress Report, January 1, 1978 - March 31, 1978. BNWL-2260-6. Battelle, Pacific Northwest Labs, Richland, WA.

[27] L.C. Schwendiman et al. Study of Plutonium Oxide Leak Rates from Shipping Containers, Quarterly Progress Report, April 1, 1978 - June 30, 1978. BNWL-2260-7. Battelle, Pacific Northwest Labs, Richland, WA.

[28] L.C. Schwendiman et al. Study of Plutonium Oxide Leak Rates from Shipping Containers, Quarterly Progress Report, October 1, 1978 - December 29, 1978. BNWL-2260-9. Battelle, Pacific Northwest Labs, Richland, WA.

[29] L.C. Schwendiman et al. Study of Plutonium Oxide Leak Rates from Shipping Containers, Quarterly Progress Report, January 1, 1979 - March 30 , 1979. BNWL-2260-10. Battelle, Pacific Northwest Labs, Richland, WA.

[30] L.C. Schwendiman et al. Study of Plutonium Oxide Leak Rates from Shipping Containers, Quarterly Progress Report, April 2, 1979 - June 29, 1979. BNWL-2260-11. Battelle, Pacific Northwest Labs, Richland, WA.
[31] L.C. Schwendiman. Estimating Particle Release Through Gas Leaks in Dry Powder Shipping Containers. BNWL-SA-6093. Battelle, Pacific Northwest Labs, Richland, WA, June 1977. Presented at the Health Physics Society 22nd Annual Meeting Atlanta, GA, July 3-8, 1977.

[32] L.C. Schwendiman et al. Research Progress on Particle Transmission Through Very Small Openings. PNL-SA-6767, CONF-780506-40. Battelle, Pacific Northwest Labs, Richland, WA. Presented at the 5th Int. Symp. on Packaging and Transportation of Radioactive Materials, Las Vegas, NV, May 7-12, 1978.

[33] L.C. Schwendiman. Supporting Information for the Estimation of Plutonium Oxide Leak Rates Through Very Small Apertures. BNWL-2198. Battelle, Pacific Northwest Labs, Richland, WA, January 1977.

[34] L.C. Schwendiman and S.L. Sutter. Transport of Particles Through Gas Leaks-A Review. BNWL2218. Battelle Pacific Northwest Laboratories, Richland, WA, January 1977.

[35] A.H. Shipiro. The Dynamics and Thermodynamics of Compressible Fluid Flow. Vol. 1., New York: The Ronald Press Co., 1953.

[36] S.L. Sutter et al. "Depleted Uranium Dioxide Powder Flow Through Very Small Openings." Nuclear Technology 52 (1981): 100.

[37] S.L. Sutter. "Powder Aerosols Generated by Accidents: Pressurized Release Experiments." Am. Ind. Hyg. Assoc. J. 44, no. 6 (1983): 379.

[38] S.L. Sutter et al. Depleted Uranium Dioxide Powder Flow Through Very Small Openings. NUREG/CR-1099. Battelle Pacific Northwest Laboratories, Richland, WA, February 1980.

[39] C. Vallepin et al. "A Review of Information on Flow Equations for the Assessment of Leaks in Radioactive Transport Containers." CEA-CONF10022. In Proceedings of the 16th Int. Symp. on Packaging and Transport of Radioactive Material, 1989.

[40] E.W. Washburn. Phys. Rev. 17 (1921): 273.

[41] J.D. Yesso et al. Study of Plutonium Oxide Powder Emissions from Simulated Shipping Container Leaks. NUREG/CR-1302, PNL-3278. Battelle Columbus Laboratories, 1980. 


\begin{tabular}{|c|c|}
\hline $\begin{array}{l}\text { NRE FORM } 335 \\
\text { (2.891 } \\
\text { NRCM } 1102, \\
3201,3202 \\
\text { BIBLIOGRAPHIC DATA SHEET } \\
\text { (See instructions on the reverse) }\end{array}$ & $\begin{array}{l}\text { 1. REPORT NUMBER } \\
\text { (Assigned by NRC., Add Vol., Supo., Fev., } \\
\text { and Addendum Numbers, if any.) } \\
\text { NUREG/CR-6487 } \\
\text { UCRL-ID-124822 }\end{array}$ \\
\hline \multirow[t]{2}{*}{ Containment Analysis for Type B Packages Used to Transport Various Contents } & DATE REPORT PUBLISHED \\
\hline & \begin{tabular}{l|l|} 
MONTH & YEAR \\
NOVEmber & 1996 \\
4. FIN OR GRANI NUMBER \\
A0291
\end{tabular} \\
\hline 5. AUTHORIS) & $\begin{array}{l}\text { 6. TYPE OF REPORT } \\
\text { Technical }\end{array}$ \\
\hline B. L. Anderson, R. W. Carlson, L. E. Fischer & 7. PERIOD COVERED (Inclusive Dates) \\
\hline
\end{tabular}

8ERFORMING ORGAN
name and mailing address.)

Lawrence Livermore National Laboratory

7000 East Avenue

Livermore, CA 94550

9. SPONSORING ORGANIZATION - NAME AND ADDRESS IIf NRC, type "Same as above"; if contractor, provide NRC Division, Office or Region, U.S. Nuclear Regulatory Commission, and mailing address.)

Office of Nuclear Material Safety and Safeguards

Spent Fuel Project Office

U.S. Nuclear Regulatory Commission

Washington. DC 20555-0001

10. SUPPLEMENTARY NOTES

11. ABSTRACT (200 words or less)

This report presents sample calculations and examples of leakage rates calculated for various contents in Type B packages.

Samples of acceptance standard leakage rates are developed for specific contents types at normal transport conditions and at hypothetical accident conditions. The leakage rates are expressed as allowable standard leakage rates. The types of contents considered include: (1) powders, (2) liquids, (3) irradiated fuel rods, (4) gases, and (5) solids. 